\title{
RECENT LEGISLATIVE AND REgULATORY DEVELOPMENTS OF INTEREST TO ENERGY PraCtITIONERS
}

\author{
CAROLyn Milne, ViVeK WARRIER, \\ DEIRDRE SHEEHAN, AND BLAKE WiLliams*
}

\begin{abstract}
This article provides an overview of recent regulatory and legislative developments from May 2017 to April 2018 of interest to energy lawyers. This includes the legal, political, and economic background to, and consequences of, new legislation and regulatory regimes. Also included are discussions of recent and ongoing judicial and regulatory decisions involving energy law. Topics discussed include market access and pipeline matters, climate change regulation, impact assessment changes, Aboriginal consultation, and abandonment liability.
\end{abstract}

\section{TABle OF Contents}

I. INTRODUCTION . . . . . . . . . . . . . . . . . . . . . . . . . . . 579

II. MARKet Access ANd PiPeline Matters $\ldots \ldots \ldots \ldots \ldots \ldots \ldots \ldots 58$

A. Status Update On Major Pipelines

AND MARKET ACCESS PROJECTS $\ldots \ldots \ldots \ldots \ldots \ldots \ldots . \ldots . \ldots 58$

B. BILL C-48: THE OIL TANKER MoRATORIUM ACT . ......... 586

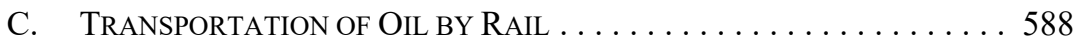

D. NEB Abandonment Cost Estimates REVIEW . . . . . . . . . . 589

E. NEB DECISION ON MARITIMES \& NORTHEAST

Pipeline Competitive Toll ApPlication . . . . . . . . . . . . 590

F. IMPLEMENTATION OF BRITISH COLUMBiA'S

New SPILl Response Regime . . . . . . . . . . . . . . . . . . . . . 591

G. LNG CANADA'S APPROVAL TO EXTEND

EXPORT COMMENCEMENT EXPIRY DATE . .............. 595

H. NATional ENERgy BoARd Procedural UPdATES . . . . . . . 595

I. NEB NORTHEASTERN BRITISH COLUMBIA

TOLLING DECISION $\ldots \ldots \ldots \ldots \ldots \ldots \ldots \ldots \ldots \ldots \ldots$

III. Climate Change and Greenhouse Gas Emissions $\ldots \ldots \ldots \ldots . \ldots 596$

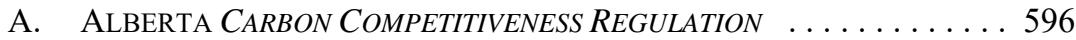

B. Alberta Energy Regulator Draft

Directives 60 and 17-Reducing Methane Emissions _.... 599

C. Status Update: Canada's Climate Change Plan ........ 599

D. AMENDMENTS TO ONTARIO'S

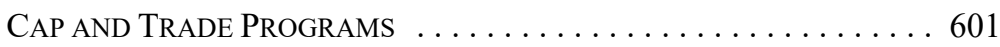

IV. ENVIRONMENTAL ISSUES AND IMPACT ASSESSMENT $\ldots \ldots \ldots \ldots \ldots 602$

A. Bill C-68: AN ACT TO AMEND THE FISHERIES ACT

AND OTHER ACTS IN CONSEQUENCE, $2018 \ldots \ldots \ldots \ldots \ldots \ldots \ldots 6 . \ldots 62$

B. BILl C-69: CANADIAN ENERGY REGULATOR ACT . . . . . . . . 605

C. BILl C-69: IMPACT ASSESSMENT ACT . . . . . . . . . . . . . 608

D. Bill C-69: Canadian NaVigable Waters ACt $\ldots \ldots \ldots \ldots 613$

Carolyn Milne is Senior Legal Counsel at Shell Canada. Vivek Warrier, Deirdre Sheehan, and Blake Williams are partners at Bennett Jones LLP. The authors would like to extend their thanks to Stephanie Ridge, Micaela Zila, Alexa Verspoor, Charlotte Teal, Graeme Melcher, Nick Bryanskiy, Venetia Whiting, David Bursey, and other colleagues at Bennett Jones LLP for their contributions to this article. 
E. WOODLAND CARIBOU RECOVERY STRATEGY:

AlBerta's Draft WoOdLAND CARIBOU RANGE Plan . . . . . . . . 616

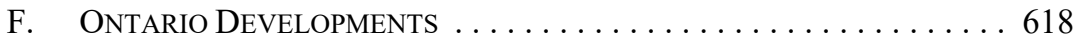

G. British Collumbia Legislative Updates . . . . . . . . . . . 621

H. Alberta Wetland Policy . . . . . . . . . . . . . . . 624

V. Aboriginal LaW ANd the Duty to Consult . . . . . . . . . . . . . . . . 627

A. Aboriginal Consultation Developments . . . . . . . . . 627

B. Extractive SECTOR TRANSPARENCY MEASURES ACT IN

EFFECT FOR PAYMENTS TO INDIGENOUS GOVERNMENTS . . . . . . . 630

C. Bill C-262 AND THE IMPLEMENTATION OF UNDRIP . . . . . . . 632

VI. BANKRUPTCY AND ABANDONMENT LIABILITY . . . . . . . . . . . 633

A. BANKRUPTCY AND INSOLVENCY

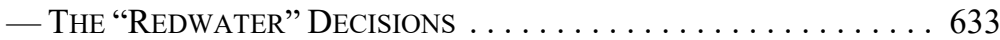

B. Alberta Energy Regulator Directive $67 \ldots \ldots \ldots 64$

C. INTRODUCTION OF THE BRITISH COLUMBIA

ORPHAN SiTE RECLAMATION FUND LEVY . . . . . . . . . . . . . . . 636

VII. Power Markets and Renewable Programs $\ldots \ldots \ldots \ldots \ldots \ldots . \ldots 66$

A. Power Purchase AgreEments

AND THE BALANCING POOL . . . . . . . . . . . . . . . . 636

B. Renewable Energy Programs in

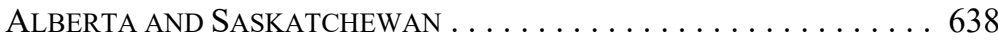

C. Bill 13: AN ACT to SECURE

ALBERTA's ELECTRICITY FUTURE . . . . . . . . . . . . . . . . . . . 643

D. Alberta Utilities COMMISSION

DECISIONS OF INTEREST . . . . . . . . . . . . . . . . . . . . . . . . . . . . 643

E. British COLUMBIA Hydro's STANDING OFFER

Programs: Five Offers Made to First Nations . . . . . . . . . 646

F. Alberta Utility COMMission - Alberta ENVIRONMENT

AND PARKS AGREEMENT ON RESPONSIBILITIES

REGARDing Wind AND SOlAR POWER Plants . . . . . . . . . . . 647

G. REClamation CERTIFICATE REQUiREMENT

INTRODUCED FOR RENEWABLE POWER PROJeCTS . . . . . . . . . . . . 647

H. British Columbia Site C Decision . . . . . . . . . . . . . . . 647

VIII. Notable Decisions Before the Alberta EnERGy

Regulator AND the Alberta Utilities COMMission . . . . . . . . . . . . 649

A. Prosper Petroleum Ltd. Rigel Oilsands Project

— AER APPLICATION No. 1778538 . . . . . . . . . . . . . . . 649

B. BASHAW OIL CORPORATION: APPLICATIONS FOR

PROXIMITY CRITICAL SOUR WELlS:

Nisku Formation, Drayton VAlley AREA . . . . . . . . . . 651

C. White Spruce Pipeline Project

— DECISION 2018 ABAER $001 \ldots \ldots \ldots$. . . . . . . . . . . . 652

D. JASPER INTERCONNECTION PROJECT

— AUC PRoceEding 22125 . . . . . . . . . . . . . . . . 654

E. Performance-BASEd Regulation REBASING AND

FIRST COMPLIANCE FILING - DECISION 22394-D01-2018 . . . . 655 


\section{F. Alberta Utilities Commission Imposes PenAlty \\ ON WIND FARM FOR BREACH OF WILDLIFE CONDITIONS . . . . . . . . 657 \\ G. First MARKeT PARTICIPANT ChOICE DeCision

\section{INTRODUCTION}

It was yet another tumultuous year in the energy, legislative, and regulatory sphere in Canada for 2017. Evolving market conditions and an increasingly polarized policy environment combined to exacerbate an emerging fluidity in Canada's regulatory framework, leaving regulatory and energy lawyers with the unenviable task of combatting the deep impression of instability this has projected to both domestic and international energy investors. One of the primary drivers of this disruption has been the efforts of governments, both federal and provincial, to reconcile aspirational climate and environmental objectives with the need to facilitate the resource development critical to national economic sustainability. This tension has manifested itself at the constitutional level through the ongoing rhetorical cage match over market access for Alberta crude and through the introduction of potentially transformational energy-related legislation at every level of government.

In the form of Bill C-69, ${ }^{1}$ the federal government has undertaken, with the avowed purpose of restoring confidence in the national energy regulatory process and placating demands for social license, a foundational restructuring of the nature and scope of regulatory review of projects within its jurisdiction. The Alberta provincial government continued to pursue an ambitious climate change agenda through its Carbon Competitiveness Incentive Regulation $^{2}$ and other legislation tabled over the course of 2017. Change continued apace in Alberta's power sector with the ongoing transition toward a capacity market and the launch of the Renewable Electricity Program. These developments and many more across the country made 2017 a year of particular magnitude for regulatory practitioners and energy lawyers generally.

This article retrospectively explores the legislative and regulatory developments that have transpired since the last review, primarily from May 2017 to April 2018, including regulatory decisions of interest to energy lawyers and announced policies that have yet to crystallize into legislation. Effort has been made to avoid duplication with developments covered in the 2018 article "Recent Judicial Decisions of Interest to Energy Lawyers." ${ }^{3}$ In the tradition of the annual update, the scope of this article spans from approximately May 2017 to April 2018 and does not include developments that have occurred after this time frame.

An Act to enact the Impact Assessment Act and the Canadian Energy Regulator Act, to amend the Navigation Protection Act and to make consequential amendments to other Acts, 1st Sess, 42nd Parl, 2015-16-17-18 (as passed by the House of Commons 20 June 2018) [Bill C-69].

Alta Reg 225/2017 [CCIR]

Olivia C Dixon, Colin Feasby \& Jung Lee, "Recent Judicial Decisions of Interest to Energy Lawyers" (2018) 56:2 Alta L Rev 479. 


\section{Market AcCess AND Pipeline Matters}

\section{A. Status Update On Major Pipelines AND MARKet ACCESS Projects}

It has also been a busy year for major pipeline projects and their related facilities. The following is a brief summary of activity.

\section{TRANSCANADA PiPELINES LTD.}

\section{a. Energy East}

On 5 October 2017, TransCanada PipeLines Ltd. (TransCanada) announced that it would not proceed with its application for the Energy East pipeline and Eastern Mainline project. The proposed Energy East pipeline project would have stretched 4,500 kilometres from Alberta and Saskatchewan to refineries in Eastern Canada and a marine terminal in New Brunswick, and carried 1.1 million barrels of crude oil per day.

Energy East's regulatory process was marked by difficulties. On 9 September 2016, the original National Energy Board (NEB) review panel recused themselves for a potential conflict of interest following allegations that two members met with a TransCanada lobbyist in $2015 .^{4}$ This resulted in significant delays to the regulatory process, which ultimately restarted in January 2017..$^{5}$ In August 2017, the NEB released the project's new scope of assessment. In addition to the factors included in the project's earlier scope of assessment, the NEB added several additional areas of inquiry in response to public interest. First, and despite its finding that upstream production and downstream use are not within TransCanada's control, it determined that the environmental impact assessment would include indirect greenhouse gas emissions in its public interest determination. The NEB also added the potential environmental and socio-economic effects of marine shipping to the scope of assessment. ${ }^{6}$ TransCanada suspended its application shortly after this scope was announced.

In its regulatory filing to the NEB withdrawing its application a month later, the company cited "existing and likely future delays resulting from the regulatory process, the associated cost implications and the increasingly challenging issues and obstacles" as reasons for its decision. $^{7}$ online: <https://www.canada.ca/en/national-energy-board/news/2016/09/energy-east-hearing-panelsteps-down.html >; The Canadian Press, "NEB Confirms Review Panel for Energy East Pipeline Proposal," CBC News (10 January 2017), online: <www.cbc.ca/1.3928721>.

5 National Energy Board, News Release, "Energy East Hearing to Restart From the Beginning" (27 January 2017), online: < https://www.canada.ca/en/national-energy-board/news/2017/01/energy-easthearing-restart-beginning.html $>$.

$6 \quad$ Letter from Sheri Young to All interested parties (23 August 2017), NEB File OF-Fac-Oil-E266-201401 02, online: <https://www.ceaa-acee.gc.ca/050/documents/p80079/120778E.pdf>.

7 Letter from Kristine Delkus to Sheri Young (5 October 2017), NEB File OF-Fac-Oil-E266-2014-01 02, online: <https://apps.neb-one.gc.ca/REGDOCS/File/Download/3336063>. 
b. Keystone XL

President Trump granted Keystone XL a cross-border permit in March 2017. In November 2017, the pipeline partially cleared its final regulatory hurdle when Nebraska approved an alternative route for the Keystone XL pipeline. Following the announcement, TransCanada announced that it would review this route's impact on the cost and schedule of the project. ${ }^{8}$

In January 2018, TransCanada announced that it had successfully concluded the Keystone XL open season and secured approximately 500,000 barrels per day of firm, 20-year commitments. ${ }^{9}$ Primary construction is expected to begin in 2019.

\section{c. Prince Rupert Gas Transmission}

The Prince Rupert Gas Transmission line (PRGT) was a proposed 900 kilometres pipeline from the North Montney Mainline (NMML), to transport natural gas from Hudson's Hope in Northeastern British Columbia to the proposed Petronas Pacific Northwest LNG export facility on the coast of British Columbia. The NMML, discussed below, is proposed to connect with the existing NOVA Gas Transmission Ltd. (NGTL) pipeline system, both of which are federally regulated.

Michael Sawyer brought an application pursuant to section 12 of the National Energy Board $A c t^{10}$ for a determination by the NEB that PRGT was subject to federal jurisdiction and NEB regulation. The NEB held that a prima facie case had not been established that the pipeline was subject to federal jurisdiction. If the NEB had been satisfied that a prima facie case for jurisdiction had been made out, it would have proceeded to a full hearing on the question of whether it had jurisdiction over PRGT.

Sawyer appealed to the Federal Court of Appeal. In July 2017, the Federal Court allowed Sawyer's appeal in Sawyer v. TransCanada Pipeline Limited. ${ }^{11}$

The Court held that the NEB erred in its interpretation of whether there was a prima facie case that PRGT was a federal undertaking ${ }^{12}$ and in its application of the test established in Westcoast Energy Inc. v. Canada (National Energy Board), ${ }^{13}$ which provides that an otherwise local work or undertaking is part of a federal work or undertaking if they are "functionally integrated and subject to common management, control and direction." "The Court held that the NEB placed too much emphasis on the facts that PRGT was proposed to be wholly located within British Columbia and was characterized as a "local merchant line"

TransCanada Corporation, News Release, "TransCanada Evaluating Nebraska PSC Decision on Keystone XL" (20 November 2017), online: <https://www.transcanada.com/en/announcements/201711-20transcanada-evaluating-nebraska-psc-decision-on-keystone-xl>. 
designed to serve the interest of a single customer. ${ }^{15}$ Rather, the Court ruled that the NEB had failed to consider the relationship between the PRGT, NMML, and the NGTL system as whole and the role PRGT played in moving gas from the Western Canadian Sedimentary Basin, through its connection to NMML and NGTL, to foreign markets for export. ${ }^{16}$ Second, the Court found that the NEB erred in confusing the business model of PRGT, such as commercial and billing arrangements (that of a single shipper), with the undertaking. ${ }^{17}$ The Court was clear that the business model of the PRGT - that it carries gas for one customer - cannot displace an otherwise prima facie case of functional integration with a federal undertaking. ${ }^{18}$ Third, the Court held that the NEB failed to identify and consider evidence regarding "common direction and control" of TransCanada and rather focused on PRGT having a different management team. ${ }^{19}$

The Court therefore allowed the appeal and remitted the application to the NEB for redetermination. ${ }^{20}$

A few days following the release of the Federal Court decision, Petronas announced that it would not be proceeding with its planned Pacific Northwest LNG terminal at the terminus of the pipeline. Following submissions from Sawyer and TransCanada, given that the facts had materially changed since the NEB had rendered its decision regarding jurisdiction over the PRGT, the NEB dismissed Sawyer's application, without prejudice. ${ }^{21}$

TransCanada has stated that it is reviewing its options with respect to the project. ${ }^{22}$

\section{d. North Montney Mainline}

The NMML originally received federal government approval under the NEBA in June 2015, resulting in the NEB issuing Certificate GC-125 for the project. ${ }^{23}$ In March 2017, NGTL filed a variance application of Certificate GC-125, including requested amendments to allow the gas to flow east, to proceed with certain components of the NMML independently of any final investment decisions related to liquefied natural gas exports from the west coast of British Columbia, and an extension of the sunset clause (the Variance Application).

The Variance Application was heard together with several applications made pursuant to section 58 of the NEBA for additional meter stations in January and February 2018. Issues considered by the NEB on the Variance Application included the need for the facilities, the

Sawyer, supra note 11 at para 51.

Ibid at paras $37,46,57$

Ibid at para 38 .

Ibid at para 66

Ibid at para 72 .

Ibid at para 76.

Letter from L Mercier, A Scott \& D Côté to William J Andrews, Marilyn Carpenter \& Joel Forrest (6 October 2017), NEB File OF-Fac-PipeGen-T211 03 0201, online: <https://www.trackenergyregs.ca/cga/ neb/en/235912/1/document.do>.

22 TransCanada Corporation, "Prince Rupert Gas Transmission Project," online: $<\mathrm{https}: / / \mathrm{www}$.transcanada. com/en/operations/natural-gas/prince-rupert-gas-transmission-project/>.

23 National Energy Board, "Certificate GC-125" (Issued 10 June 2015 pursuant to hearing order GH-0012014), online: <https://apps.neb-one.gc.ca/REGDOCS/File/Download/2788776>. 
commercial impacts of the application, and the appropriateness of the tolling methodology for the NMML. ${ }^{24}$

A decision on the proceeding is expected in May 2018.

\section{ENBRIDGE PIPELINES INC.}

a. Line 3 Replacement Project

Enbridge Pipelines Inc. (Enbridge) began construction of the Canadian portion of the Line 3 Replacement Project (Line 3) in August 2017, which involves the replacement of 1,067 kilometres of pipeline between Hardisty, Alberta and Gretna, Manitoba with 1,096 kilometres of new pipe, and the installation of new facilities valves, pump stations, interconnections, and oil storage tanks. Line 3 was approved on 25 April 2016 with 89 conditions.

The pipeline in-service date is expected to be 2019, pending regulatory approval in the United States. ${ }^{25}$ The American portion of Line 3 stretches 1,765 kilometres from Neche, North Dakota, through Minnesota, to Superior, Wisconsin. The Minnesota Public Utilities Commission (PUC) ruled the final environmental review "adequate" for the American portion of Line 3 on 15 March 2018. The PUC's decision on whether to issue a necessary certificate of need and route is expected in summer 2018.

In the meantime, based on evidentiary hearings held in November 2017, an American administrative law judge delivered a report to the PUC on 24 April 2018, stressing the importance of the pipeline and recommending that Enbridge construct the new Line 3 parallel to the existing route and within the existing right-of-way. While the PUC is not bound by the judge's decision, the route recommended in the decision crosses the territories of two Indigenous groups who oppose the project, which may increase the likelihood of future legal challenges by opponents of the pipeline. ${ }^{26}$

\section{b. Line 21 Replacement Project}

Enbridge Line 21 is an active pipeline that carries crude oil 870 kilometres from Norman Wells, Northwest Territories to Zama City, Alberta. The pipeline has been shut down since Enbridge identified potential slope instability approaching the Mackenzie River in November 2016. On 25 January 2018, the NEB approved Enbridge's application to replace the 2.5 kilometre segment of pipe in question and decommission the old pipe. ${ }^{27}$ The NEB also

National Energy Board, "Hearing Order MH-031-2017" (Reply Argument of Westcoast Energy Inc carrying on business as Spectra Energy Transmission at paras 23-24), online: $<$ https://apps.neb-onegc.ca/REGDOCS/File/Download/3460947>.

25 Enbridge Inc, "Line 3 Replacement Program (Canada)," online: <https://www.enbridge.com/Projectsand-Infrastructure/Projects/Line-3-Replacement-Program-Canada.aspx $>$.

26 Enbridge Inc, "2018 First Quarter Report" (31 March 2018) at 47, online: $<$ https://www.enbridge.com/ investment-center/reports-and-sec-filings/ $\sim$ media/Enb/Documents/Investor\%20Relations/2018/2018 ENB Q1 MDAandFS.pdf>.

27 National Energy Board, "Reasons for Decision: Enbridge Pipelines (NW) Inc. MH-001-2017"(January 2018), online: $<$ https://cabinradio.ca/wp-content/uploads/2018/01/A89554-1-NEB-Reasons-for-Decis ion-MH-001-2017-Enbridge-Line-21-Segment-Replacement-A5Z6G1.pdf $>$. 
attached 26 mandatory project conditions to its approval of the project, including the preparation and filing of an Indigenous Monitoring Plan with the NEB. This plan will describe how local Indigenous peoples will participate in monitoring project construction and post-construction. Enbridge must also file Indigenous Engagement Reports and an Indigenous Knowledge and Land Use Study Update.

\section{Kinder Morgan Trans Mountain PiPELINE EXPANSION}

The Kinder Morgan Trans Mountain Pipeline Expansion (Trans Mountain) received NEB approval in 2016. Despite ongoing preparatory work in anticipation of pipeline construction starting in summer 2018, Kinder Morgan encountered several legal challenges in the last year, and has now suspended all non-essential activities and spending. ${ }^{28}$

In October 2017, the Federal Court of Appeal heard the consolidated judicial review of the Order in Council which approved the Trans Mountain pipeline on the basis of inadequate consultation with First Nations and statutory issues. The hearing included submissions from the Attorney General of British Columbia who was granted intervener status on 29 August $2017 .^{29}$ At the time of writing, a decision has not been released.

Separately, on 23 March 2018, the Federal Court of Appeal declined to hear an appeal by the City of Burnaby challenging the NEB's decision that Kinder Morgan is not required to comply with certain City of Burnaby bylaws that interfere with the construction of the Trans Mountain pipeline. ${ }^{30}$ Mayor Derek Corrigan of Burnaby has publicly directed the City's legal counsel to file an appeal to the Supreme Court of Canada.

The Federal Court of Appeal also released its decision in Coldwater Indian Band $v$. Canada (Indian and Northern Affairs) on 26 September $2017 .{ }^{31}$ The Court set aside the Minister's decision to approve the assignment of an easement on the Kinder Morgan Trans Mountain pipeline. The Minister's decision was found to be unreasonable as a result of the failure to assess the current and ongoing impact of the continuation of the right-of-way on the Coldwater Indian Band's right to use and enjoy its lands. The matter was remitted back to the Minister for redetermination.

In the meantime, both the Squamish Nation and the City of Vancouver filed applications for judicial review of British Columbia's Environmental Assessment Certificate (EAC) granted by the province on 10 January 2017 on the basis of inadequate consultation. ${ }^{32}$ The British Columbia Supreme Court quashed both actions on 24 May $2018 .{ }^{33}$ In both cases, the

A full list of legal challenges to the NEB's approval of the Trans Mountain Pipeline Expansion Project can be found in National Energy Board, "Court Challenges to National Energy Board or Governor in Council Decisions," online: <https://www.neb-one.gc.ca/pplctnflng/crt/index-eng.html>.

29 Tsleil-Waututh Nation v Canada (AG), 2017 FCA 174.

30 City of Burnaby v Trans Mountain Pipeline ULC, leave to appeal to FCA refused, 18-A-9 (23 March 2018).

2017 FCA 199.

32 Squamish Nation Chiefs and Council, News Release, "Squamish Nation Go to Court to Challenge the BC Government's Decision to Approve the Kinder Morgan Project" (20 April 2017), online: $<$ http://www.squamish.net/wp-content/uploads/2017/04/2017-04-20-Media-Release-SN-challenge-Provdecision-to-approve-KM-01358360.pdf>.

33 Vancouver (City) v British Columbia (Environment), 2018 BCSC 843 [City of Vancouver]; Squamish Nation v British Columbia (Environment), 2018 BCSC 844 [Squamish Nation]. 
Court found that the decision of the Ministers of the Environment and of Natural Gas Development to issue the EAC was reasonable and fell within the range of possible, defensible outcomes, and found no lack of procedural fairness or absence of jurisdiction. ${ }^{34}$

a. Alberta's Response - Bill 12:

Preserving Canada's Economic Prosperity Act

Earlier this year, the Government of British Columbia proposed new restrictions on Alberta bitumen, including restricting shipments of oilsands crude in pipelines and on railways. $^{35}$

The Government of Alberta has taken the position that the action by British Columbia is unconstitutional given the division of power over interprovincial trade and commerce. ${ }^{36} \mathrm{On}$ 16 April 2018, the Government of Alberta introduced Bill 12: Preserving Canada's Economic Prosperity Act. ${ }^{37}$ Bill 12 proposes to give the Alberta Minister of Energy (the Minister) sweeping powers to control the export of natural gas, crude oil, and refined fuels from Alberta using export licenses.

Under Bill 12, the Minister may issue an order designating that a person or a class of persons are required to obtain a license to export any quantity of natural gas, crude oil (excluding crude bitumen), or refined fuels (including gasoline, diesel, and jet fuel) from the province. While Bill 12 would empower the Minister to impose export licenses, the government has indicated that it will only take action if it deems it necessary. ${ }^{38}$

In issuing, amending, or renewing a license under the proposed Bill 12, the Minister has broad discretion to impose any terms and conditions as part of the license. The Minister is also empowered to suspend, revoke, or amend a license if he or she determines that it is in the public interest of Alberta to do so.

Bill 12 passed Third Reading on 16 May 2018, and will come into force on proclamation. ${ }^{39}$ British Columbia has indicated its intention to bring an action challenging its constitutional validity in the courts of Alberta if Bill 12 becomes law. On 22 May, the Government of British Columbia filed a statement of claim in the Alberta Court of Queen's Bench challenging the constitutionality of the Act. ${ }^{40}$

City of Vancouver, ibid at para 15; Squamish Nation, ibid at para 13.

Government of British Columbia, News Release, "Additional Measures Being Developed to Protect B.C.'s Environment From Spills" (30 January 2018), online: < https://news.gov.bc.ca/releases/2018 ENV0003-000115>.

Government of Alberta, News Release, "B.C. Move to Restrict Bitumen: Premier Notley" (30 January 2018), online: <https://www.alberta.ca/release.cfm?xID=52329D9B4E5A5-D631-5FBB-EDBECEF 2D724B4CD>

4th Sess, 29th Leg, Alberta, 2018 (assented to 18 May 2018), SA 2018, c P-21.5 [Bill 12].

Government of Alberta, News Release, "Preserving Canada's Economic Prosperity" (16 April 2018), online: <https://www.alberta.ca/release.cfm?xID=5577521DB8331-DC67-2CA2-BA443B43F804E $3 \mathrm{~A} 4>$.

Bill 12, supra note 37, cl 13.

Government of British Columbia, News Release, "British Columbia Files Constitutional Challenge of Alberta Legislation" (22 May 2018), online: <https://news.gov.bc.ca/17194>. 
b. The Federal Response

In response to this conflict, the federal government has expressed its general support for actions that benefit the Canadian economy, including the proposed Trans Mountain pipeline. In April 2018, Prime Minister Justin Trudeau met with the premiers of Alberta and British Columbia in an attempt to resolve the issue. The federal government maintains that the project is in the national interest and the Trans Mountain pipeline should be built. ${ }^{41}$

On 15 May 2018, Federal Finance Minister Morneau announced that the federal government is willing to compensate Kinder Morgan for any financial loss it suffers as a result of British Columbia's attempts to obstruct the Trans Mountain Pipeline. ${ }^{42}$

\section{c. British Columbia's Response}

British Columbia has taken the position that it has authority under the British Columbia Environmental Management $A c t^{43}$ to protect the provincial coastline and environment. ${ }^{44} \mathrm{On}$ 26 April 2018, the British Columbia government submitted a reference question to the British Columbia Court of Appeal. In the reference, it asked the Court to review proposed amendments to the Environmental Management Act that would give the British Columbia government authority to regulate the impacts of heavy oil, including diluted bitumen. ${ }^{45}$

\section{B. BiLl C-48: THE OIL TANKER MoRAtorium ACT}

On 12 May 2017, the federal government introduced Bill C-48, An Act respecting the regulation of vessels that transport crude oil or persistent oil to or from ports or marine installations located along British Columbia's north coast, ${ }^{46}$ which would enact the Oil Tanker Moratorium Act (OTMA). Bill C-48 is part of the federal government's larger Oceans Protection Plan strategy, which includes $\$ 1.5$ billion in new funding for marine safety and ecosystem research. ${ }^{47}$

OTMA would prohibit oil tankers carrying crude and persistent oils as cargo from stopping, mooring, loading, or unloading at ports or marine installations in northern British Columbia, but would not prohibit passage through the area. ${ }^{48}$ The moratorium area would extend from the Canada/Alaska border in the North, down to the northern tip of Vancouver

Department of Justice Canada, News Release, "Government of Canada to Intervene in Trans Mountain Pipeline Reference” (3 May 2018), online: <https://www.canada.ca/en/department-justice/news/2018/05/ government-of-canada-to-intervene-in-trans-mountain-pipeline-reference.html $>$. Department of Finance Canada, News Release, "Securing Canada's Economic Future: Minister Morneau Speaks at Toronto Region Board of Trade" (17 May 2018), online: <https://www.canada.ca/en/ department-finance/news/2018/05/securing-canadas-economic-future-minister-morneau-speaks-attoronto-region-board-of-trade.html>.

$43 \quad$ SBC 2003, c 53 [EMA].

44 Government of British Columbia, News Release, "Province Submits Court Reference to Protect B.C.'s Coast" (26 April 2018), online: <https://.news.gov.bc.ca/16948>.

Ibid.

1st Sess, 42nd Parl, 2015-16-17 (third reading 8 May 2018) [Bill C-48].

Prime Minister of Canada, News Release, "The Prime Minister of Canada Announces the National Oceans Protection Plan" (7 November 2016), online: <https://pm.gc.ca/eng/news/2016/11/07/primeminister-canada-announces-national-oceans-protection-plan $>$.

Bill C-48, supra note 46, cl 4. 
Island. Vessels carrying less than 12,500 metric tonnes of crude or persistent oil as cargo will continue to be permitted in the moratorium area. ${ }^{49}$

Under OTMA, crude oil includes "any liquid hydrocarbon mixture that occurs naturally in the earth ... whether or not it has been treated to render it suitable for transportation." Persistent oils are defined in a schedule, and include synthetic crude oils, certain condensates, and heavy blended fuel oils.$^{51}$ Liquefied natural gas, propane, gasoline, and jet fuel are exempt. ${ }^{52}$

The Minister may exempt an oil tanker from the moratorium if its operation is essential for the purpose of community or industry resupply, or is otherwise in the public interest. ${ }^{53}$ The Minister may also add or remove refined petroleum products from the schedule, ${ }^{54}$ which the federal government has indicated will be considered following an assessment of scientific and environmental safety criteria. ${ }^{55}$ The remedies and penalties for contravention may include a fine of up to $\$ 5$ million, imprisonment, detention, and sale of the vessel. Owners, directors, and officers may be parties to an offence. ${ }^{56}$

Bill C-48 passed Third Reading on 8 May 2018, whereupon it was sent to the Senate and underwent First Reading on 9 May 2018.

Bill C-48 appears to be a clear policy statement from the federal government that the export of crude oil will be supported from the south end of British Columbia only. This direction has faced opposition from certain First Nations, including the Indigenous proponents of the Eagle Spirit pipeline project that would terminate south of Prince Rupert. Eagle Spirit Energy Holdings Ltd. (Eagle Spirit) emerged in 2015 as a First Nations-led pipeline corridor between Bruderheim, Alberta and Grassy Point, British Columbia. In response to threats to the project resulting from the anticipated tanker moratorium legislation, Eagle Spirit launched a two-pronged approach. First, in 24 January 2018, Eagle Spirit's Indigenous backers launched a GoFundMe campaign to raise funds to mount a legal challenge against the tanker ban. ${ }^{57}$ At nearly the same time, Eagle Spirit also announced that it had signed a memorandum of understanding to locate the pipeline's proposed terminal in Hyder, Alaska in order to circumvent the effects of the tanker ban. ${ }^{58}$

\section{Ibid, $\mathrm{cl} 4(1)$.}

Ibid, $\mathrm{cl} 2$.

Ibid, Schedule.

Transport Canada, "Crude Oil Tanker Moratorium on British Columbia's North Coast" (12 May 2017), online: <https://www.canada.ca/en/transport-canada/news/2017/05/crude_oil_tankermoratoriumon britishcolumbiasnorthcoast.html> [Moratorium Backgrounder].

Bill C-48, supra note 46, cl 6(1).

Ibid, cl 24.

Moratorium Backgrounder, supra note 52

Bill C-48, supra note 46, cls 25-30.

Chiefs Council, "Chiefs Council Against Bill C-48" (30 November 2017), online: $<$ https://www.gofund me.com/chiefs-council-against-bill-c48>.

David Bursey et al, "Lax Kw'alaams Legal Challenge to the Federal Oil Tanker Moratorium on Canada's West Coast"'(4 April 2018), Bennett Jones (blog), online: $<$ https://www.bennettjones.com/en/ Blogs-Section/Lax-Kwalaams-Legal-Challenge-to-the-Federal-Oil-Tanker-Moratorium-on-CanadasWest-Coast>. See also Claudia Cattaneo, "First Nations Pipeline Has a Plan to Get Around B.C. Oil Tanker Ban - An Old Gold-Rush Town in Alaska," Financial Post (6 February 2018), online: $<$ https://business.financialpost.com/commodities/energy/first-nations-pipeline-has-a-plan-to-get-aroundb-c-oil-tanker-ban-an-old-gold-rush-town-in-alaska > 
Second, on 22 March 2018, the Lax Kw'alaams Indian Board and the Nine Tribes of the Lax Kw'alaams (collectively, Lax Kw'alaams) filed a legal challenge against Canada and British Columbia based on Canada's action to impose an oil tanker moratorium along the northern coast of British Columbia. ${ }^{59}$ The Lax Kw'alaams seek a court declaration that Bill $\mathrm{C}-48$, and any subsequent enactment, has no effect in Lax Kw'alaams territory.

The Lax Kw'alaams Indian Band filed this claim as a representative of the nine tribes of the Coast Tsimshian First Nation who collectively assert Aboriginal title over an area including Nasoga Gulf, Grassy Point, Lax Kw'alaams, and Tsimshian Peninsula. ${ }^{60}$ This territory is within the proposed tanker moratorium boundaries. The Lax Kw'alaams assert this area includes a deep-water corridor that would be suitable for the development of a marine terminal for the export of oil. ${ }^{61}$ The Lax Kw'alaams also assert their Aboriginal title includes "the right to choose what uses the land can be put, including use as a marine installation subject only to justifiable environmental assessment and approval legislation." 62

\section{Transportation OF OIL By RaIL}

To date, rail transportation has acted largely as a relief valve for crude oil transportation in Canada, and as such its usefulness to the oil and gas industry has fluctuated with need and operational constraints. The past year has seen significant fluctuation in crude-by-rail transportation and it would appear there will be a sharp increase in its use.

With growing uncertainty about the construction of new pipelines in Canada in 2017, arising from pipeline projects being abandoned or being slow to receive approvals, the more expensive option of rail as a means of transportation for diluted bitumen is becoming increasingly used, and is projected to continue as such in the future. ${ }^{63}$ Current market dynamics between crude producers and rail operators suggest the all-in cost of transport by rail from Western Canada to the Gulf Coast may rise due to demand and a scarcity of railcars.

\section{INCREASE IN CRUDE-BY-RAIL VOLUMES}

Given this uncertainty in increasing pipeline capacity, and the projected significant increase in Canadian oil production, due in large part to the opening of new projects like Suncor's Fort Hills facility and Canadian Natural Resources Limited's Horizon project, crude-by-rail volumes could rise sharply from 200,000 barrels per day in early 2018 to peak at 390,000 to 590,000 barrels per day in $2019 .{ }^{64}$ The previous peak for crude-by-rail was

Lax Kw'alaams Indian Band v British Columbia (AG) (22 March 2018), Prince Rupert 10683 (BCSC) (Notice of Civil Claim).

Ibid at paras 6-12, 17-22.

Ibid at para 27.

Ibid at para 28 .

International Energy Agency, Energy Policies of IEA Countries: Canada: 2015 Review (Paris: IEA, 2016) at 10, online: $<\mathrm{https}$ ://www.iea.org/publications/freepublications/publication/EnergyPoliciesof IEACountriesCanada2015Review.pdf $>$.

International Energy Agency, "Oil Market Report" (13 April 2018) at 22, online: <https://www.iea.org/ media/omrreports/fullissues/2018-04-13.pdf>. See also Nia Williams \& Ethan Lou, "Canada Expects Crude-by-Rail Boom as Pipeline Project Collapses," Reuters (6 October 2017), online: <https://ca. reuters.com/article/idCAKBN1CB2J2-OCATP>; Ian Bickis, "Crude-by-Rail Shipments to More Than Double to 390,000 Barrels a Day: IEA," Global News (5 March 2018), online: < https://globalnews.ca/ news/4064038>. 
179,000 barrels per day in September $2014 .{ }^{65}$ In 2017, approximately 140,000 barrels per day of oil (roughly 3 percent of Western Canada's production) was transported by rail, despite a much higher capacity. ${ }^{66}$

\section{MOVING TOWARD LONG-TERM TRANSPORTATION AGREEMENTS}

With increasing dependency on rail to transport oil in Canada, shortages of railcar availability have also challenged the energy industry. ${ }^{67}$ Major railways such as Canadian Pacific and Canadian National have been seeking multi-year take-or-pay contracts with energy customers, guaranteeing minimum volumes prior to assigning resources to transport the growing stockpiles of product. Such long-term agreements have the potential to incentivize and allow railways to adjust operating plans, something that is otherwise difficult for them to do quickly given operational constraints.

\section{ONGOING CONCERNS ABOUT RAIL SAFETY}

In the aftermath of the Lac Mégantic disaster on 5 July 2013, there has been an increased focus on rail safety in the industry and in regulation. While this is not a new topic for 2017, of note this year was the release of the acquittal of three Montreal, Maine \& Atlantic employees on charges of criminal negligence causing death related to the 2013 disaster. All three former employees, the locomotive engineer, a rail traffic controller, and an operations manager, were found not guilty. ${ }^{68}$

Their trial began in September 2017 and heard testimony from 31 witnesses for the prosecution over three months. In the end, the jury deliberated from 11 to 19 January 2018 before reaching a verdict of not guilty. ${ }^{69}$

\section{NEB AbANdonment Cost Estimates ReVIEW}

In February 2016, the NEB began its Abandonment Cost Estimate Review (ACE and the 2016 ACE Review, respectively). A pipeline company's ACE is the amount that a pipeline company must set aside for abandonment purposes. The purpose of the 2016 ACE Review is to "refine the assumptions and abandonment methodology that companies use to calculate

65 National Energy Board, "Feature Article: Estimates of Canadian Crude by Rail Movements Show a Peak in October 2015, Roughly One Quarter of Total Loading Capacity" (25 February 2016), online: $<$ https:// www.neb-one.gc.ca/nrg/ntgrtd/mrkt/ftrrtcl/2016-02-01 cndncrdrl-eng.html>.

66 Canadian Association of Petroleum Producers, "Infrastructure and Transportation," online: < www.capp. $\mathrm{ca} /$ canadian-oil-and-natural-gas/infrastructure-and-transportation $>$.

67 Canadian Association of Petroleum Producers, "Markets and Transportation," online: <www.canadasoil sands.ca/en/explore-topics/markets-and-transportation $>$.

68 Bouchard Mathieur c Demaitre Jean (19 January 2018), Sherbrooke 450-01-102299-174 001 (Qc CS). See also Kalina Laframboise \& Alison Brunette, "All 3 MMA Rail Workers Acquitted in Lac-Mégantic Disaster Trial," CBC News (19 January 2018), online: <www.cbc.ca/1.4474848>. 
the cost of abandonment of their pipeline systems over time," particularly given advances in technology, information sharing, and actual abandonment experience. ${ }^{70}$

On 13 February 2017, the NEB announced that it would hold a technical conference in the fall of 2017 to enable informal information exchanges between stakeholders. In anticipation of the conference, the NEB released discussion papers on nine topics and a Refined ACE Framework for comment. ${ }^{71}$

Currently, ACE values are calculated in accordance with the base cases determined in NEB Reasons for Decision MH-001-2012. ${ }^{72}$ MH-001-2012 uses a series of cost-definition grids that allow companies to classify costs within ranges. In contrast, the proposed Refined ACE Framework is significantly more granular, using an Excel spreadsheet that calculates values based on an individual company's inputs into the spreadsheet. ${ }^{73}$

The technical conference was held in Calgary in November 2017. The NEB has indicated that next steps will include the release of Final Technical Conference Reports, a Final Refined ACE Framework, a decision on Group 1 ACE values, and additional direction for Group 2 companies. $^{74}$

\section{E. NEB DECision ON MARITIMES \& NORTHEAST Pipeline Competitive Toll Application}

On 22 January 2018, the NEB issued its decision on an application from Maritimes \& Northeast Pipeline (M\&NP) for approval of a new pipeline service offering.

M\&NP had applied to the NEB for approval of a "load retention" service (LRS) and a discounted LRS toll (bypass toll) to Irving Oil in exchange for a 13-year commitment to use the M\&NP Pipeline to ship natural gas from the Canada-United States border to the Irving Oil Refinery in Saint John, New Brunswick. M\&NP said it offered the service to Irving Oil in response to a competing offer from the Emera Brunswick Pipeline Company (the EBPC Alternative).

While the NEB recognized that pipelines must adapt to changing market conditions in their markets and that M\&NP had proactively developed the LRS service and toll to respond to the perceived competition from EBPC, the NEB denied the application, stating that it was a premature response to the bypass concerns presented. The NEB made no finding as to

70

Letter from Sheri Young to Distribution List (13 February 2017), re Abandonment Cost Estimates Review 2016 - Procedural Direction No 1 - Process Decision and Schedule, NEB File OF-AF-ACE 01 at 2, online: $<$ https://apps.neb-one.gc.ca/REGDOCS/File/Download/3186291 $>$ [Procedural Direction No 1].

71 Letter from Sheri Young to List of Participants (16 August 2017), re National Energy Board Abandonment Cost Estimate (ACE) Review 2016: Release of Discussion Papers and Refined ACE Framework, NEB File OF-AF-ACE 01: A85505, online: <https://apps.neb-one.gc.ca/REGDOCS/ File/Download/3309617>.

72 National Energy Board, "Reasons for Decision: Abandonment Cost Estimates MH-001-2012" (February 2013), online: < https://apps.neb-one.gc.ca/REGDOCS/File/Download/918198>.

Procedural Direction No 1, supra note 70 at 2.

Letter from Sheri Young to List of Participants (5 May 2017), re ACE Review 2016: Procedural Direction No 2, NEB File OF-AF-ACE 01, online: < https://apps.neb-one.gc.ca/REGDOCS/Item/Filing/ A83172>. 
whether the proposed toll would be just and reasonable, and whether there would be unjust discrimination. ${ }^{75}$

In particular, the NEB was not satisfied with the portrayal of the EBPC Alternative as a credible alternative, noting that the assertion that the EBPC Alternative would require minimal regulatory review did not appear to be the case. ${ }^{76}$

The NEB recognized that "significant broad concerns and uncertainties were raised about the future of the natural gas market in the Maritimes and the impact on shippers, in particular those captive to M\&NP." $" 77$ As these concerns arose during the proceeding, not all parties with a potential interest in the broader concerns had participated. ${ }^{78}$

The NEB provided some guidance on the competitive issues at play, noting that the evidence indicated that splitting the domestic market demand between the two pipelines post2019 may challenge the viability of M\&NP, which, as a result, could affect the Maritime natural gas market unfavourably. The NEB also stated that evidence showing other load retention service applications to serve industrial loads in the Saint John area had been discussed and raised further concerns about the long-term future of the natural gas market in the Maritimes and the potential impact of load retention services on M\&NP's captive shippers.

The NEB ultimately concluded that "an examination of possible alternative toll and tariff approaches would be more fruitful when M\&NP's supply, markets and contract billing determinants post-2019 are known." 79

\section{F. IMPLEMENTATION OF BRITISH COLUMBIA'S NEW SPILl RESPONSE REgIME}

\section{PHASE ONE}

On 30 October 2017, Phase One of British Columbia's new spill response regime came into force ${ }^{80}$ The new regime requires transporters of liquid petroleum products to implement provincial spill response plans, test the plans, report on, and clean up spills. It brings into force Part 7, Division 2.1 of the Environmental Management Act, ${ }^{81}$ which deals with spill preparedness, response, and recovery, and includes three new regulations: the Spill Contingency Planning Regulation; ${ }^{82}$ the Spill Preparedness, Response and Recovery

\footnotetext{
75 National Energy Board, "Letter Decision: Maritimes \& Northeast Pipeline Management Ltd. (M\&NP)" (22 January 2018), RHW-0001-2017 at 15, online: < https://apps.neb-one.gc.ca/REGDOCS/File/Down load/3464186>.

Ibid at $15-16$

Ibid at 16.

Ibid at 16-17.

Ibid at 17.

While most of the provisions in the Regulations took effect on 30 October 2017, some provisions did not come into force until 30 April 2018 and others will not come into force until 30 October 2018. EMA, supra note 43.

BC Reg 186/2017 [SCPR].
} 
Regulation; ${ }^{83}$ and the Spill Reporting Regulation (collectively in this section, the Regulations). ${ }^{84}$

The Regulations apply to:

- " "regulated persons," which are rail and highway transporters in possession, charge, or control of 10,000 litres (62.898 barrels) or more of liquid petroleum products, and pipeline operators with any quantity of liquid petroleum products in their pipeline ${ }^{85}$ and

- “responsible persons," which are persons in possession, charge, or control of a substance when a spill occurs or is imminent. ${ }^{86}$

Parties holding permits to carry out oil and gas activities under the Emergency Management Regulation are exempt from the Spill Contingency Planning requirements. ${ }^{87} \mathrm{In}$ the case of a spill, these parties are required only to submit an initial report. ${ }^{88}$

\section{a. Background}

The previous provincial government announced its plans for a new regime on 15 June 2015 , following public criticism over the federal and provincial handling of a bunker fuel leak in English Bay and the province's 2012 announcement of the five conditions for supporting pipeline development.

\section{b. Spill Response}

The Regulations require regulated persons to prepare and maintain spill contingency plans. ${ }^{89}$ If a spill occurs, a regulated person must ensure that the spill contingency plan is implemented to the extent that it applies. ${ }^{90}$ They must also undertake numerous actions, including meeting the reporting requirements, providing requested information to an officer, responding to the spill and sending the appropriate people to the site of the spill, and ensuring that the actions necessary to address the threat or hazard caused by the spill are taken. ${ }^{91}$

In addition, regulated persons must maintain records related to spill contingency plans and the training of respondents. ${ }^{92} \mathrm{~A}$ director may order the responsible person to produce particular information, including a copy of the regulated person's spill contingency plan, details on the operations and the substances in their possession, and a declaration on their spill preparedness or response capabilities. ${ }^{93}$

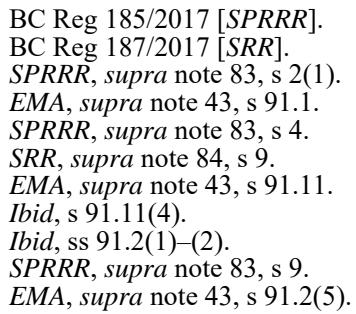




\section{c. Spill Contingency}

The SCPR requires regulated persons to produce, develop, and maintain spill contingency plans based on a worst-case scenario. ${ }^{94}$ Spill contingency plans must be reviewed and updated at least once a year and within one month of any material change. ${ }^{95}$ They must also be tested on a three-year cycle and must cover prescribed components, including the performance of duties, tasks, or operations. ${ }^{96}$

For pipeline and rail transporters, spill contingency plans had to be ready for 30 April 2018. For highway transporters, plans must be ready by 30 October $2018 .^{97}$

\section{d. $\quad$ Spill Reporting}

Reporting requirements are triggered where there is a spill of a substance listed in the Schedule of the $S R R$, other than natural gas, if:

(a) $[\mathrm{T}]$ he spill enters, or is likely to enter, a body of water, or

(b) the quantity of the substance spilled is, or is likely to be, equal to or greater than the listed quantity for the listed substance. ${ }^{98}$

For natural gas, a spill is reportable if:

- the spill is caused by a break in a pipeline or fitting operated above 100 psi that results in a sudden and uncontrolled release of natural gas, and

- the quantity of natural gas released, or likely to be, is equal to or greater than the listed quantity for natural gas (such as $10 \mathrm{~kg}$ ). ${ }^{99}$

The Spill Reporting Regulation requires a responsible person to produce three types of reports: an Initial Report, ${ }^{100}$ Update Reports (or Follow-Up Reports), ${ }^{101}$ and an End-of-Spill Report. ${ }^{102}$ If ordered by a director, the responsible person may also be required to prepare a Lessons-Learned Report. ${ }^{103}$

Only the requirements for the Initial Report and the Lessons-Learned Report (if ordered by a director) came into force on 30 October 2017. The Update Report, which includes details about the spill, its effects, and the actions taken, and the End-of-Spill Report, which

SCPR, supra note 82 , s 3 .

Ibid, $\mathrm{s} 14$.

Ibid, ss $15-16$.

SPRRR, supra note 83 , s 3(1).

SRR, supra note 84 , s 2 .

Ibid, s 3.

Ibid, $\mathrm{s} 4$.

Ibid, s 5.

Ibid, s 6.

Ibid, s 7. 
must be made within 30 days of the completion of the emergency response and must include certain information, do not come into force until 30 October 2018. ${ }^{104}$

\section{Phase Two}

Phase Two of British Columbia's spill response regime is currently underway. On 28 February 2018, the Ministry released its Intentions Paper for public comment. ${ }^{105}$ It describes four policy concepts that the Ministry is considering:

(1) Prescribing response times to ensure the timely response following a spill, including whether regulated persons should be required to demonstrate their spill contingency plans within a prescribed timeframe, and whether all high-volume regulated persons (the owners of all pipelines and railways transporting liquid petroleum products) should be required to abide by those response times;

(2) Developing of Geographic Response Plans (GRPs) to ensure resources are available to support an immediate response that takes into account the unique characteristics of a given area. The Ministry is considering whether regulated persons in particularly sensitive areas should be required to develop one of two types of GRPs (linear or "hot-spot" GRPs) for those areas;

(3) Addressing the loss of public use from spills (including economic, cultural, and recreational impacts) to ensure communities are compensated for negative impacts from spills. This may be done by allowing the Ministry to order responsible persons to develop and implement plans to compensate communities to mitigate or counteract negative impacts; and

(4) Maximizing the marine application of Ministry environmental emergency regulatory powers. In particular, the Ministry will explore whether there are opportunities to enhance provincial regulations with respect to marine spills to ensure a consistent and high standard of protection in both marine and terrestrial settings.

A Policy Update is expected for August 2018. Depending on government direction, Phase Two regulations may be implemented in early 2019.

Initially, the province announced that as part of Phase Two it would be seeking feedback on imposing restrictions on the increase of diluted bitumen transportation until the behaviour of spilled bitumen can be better understood and there is certainty regarding the ability to adequately mitigate spills. The British Columbia government subsequently removed this item from the listed policy areas it is considering in Phase Two. This issue is discussed in greater detail in Part II.A. 3 of this article.

105 British Columbia, Ministry of Environment \& Climate Change Strategy, Policy Intentions Paper for Engagement: Phase Two Enhancements to Spill Management in British Columbia (Victoria: Ministry of ECCS, 28 February 2018), online: $<$ https://www2.gov.bc.ca/assets/gov/environment/air-land-water/ spills-and-environmental-emergencies/docs/phase_two_intentions_paper_february_28_2018.pdf > 


\section{G. LNG CANADA's APPROVAL TO EXTEND EXPORT COMMENCEMENT EXPIRY DATE}

On 18 September 2017, the NEB approved the variance of LNG Canada Development Inc.'s (LNG Canada) application to extend the export commencement expiry date of License GL-330. ${ }^{106}$ This extension delays the commencement of the expiry date from 31 December 2022 to 31 December 2027, subject to the approval of the Governor in Council.

According to LNG Canada, its request for extension was in response to market uncertainty affecting project timelines and investment. ${ }^{107}$ The extension granted by the NEB in this matter will shift the timeframe over which exports occur and not extend the term of the license or its export volume allowance.

At the end of its decision, the NEB noted that all other conditions to License GL-330 remain in effect.

\section{H. National Energy Board Procedural Updates}

\section{2017 UPDATES TO THE NEB FILING MANUAL}

On 13 July 2017, the NEB released Filing Manual Revision 2017-01. ${ }^{108}$ The changes include clarifying Emergency Management filing requirements for regulated companies during the application process, compelling publication of emergency procedures manuals, and emergency management program information on company websites.

\section{AUDIT FINDINGS INFORMATION ADVISORY}

On 16 November 2017, the NEB released a series of audit reports as part of its new focused audit process. ${ }^{109}$ Under this approach, the NEB focuses on certain existing audit elements every year across multiple companies. ${ }^{110}$ This year, the NEB audits focused on investigating and reporting incidents and near-misses, and inspection measurement and monitoring.

In addition to releasing the audit reports, the NEB also released an Information Advisory (IA) stating that the NEB expected all regulatory companies to use the audit findings to

Letter from Sheri Young to Lars Olthafer \& Lisa Jamieson (18 September 2017), re LNG Canada Development Inc (LNG Canada) Application to Extend Export Commencement Expiry Date, Licence GL-330, NEB File OF-EI-Gas-GL-L384-2015-0101 at 4, online: <https://apps.neb-one.gc.ca/REG DOCS/File/Download/3328492>.

WG World News, News Release, "LNG Canada Allowed to Push Back Export Start Date" (22 September 2017), online: <https://www.Ingworldnews.com/lng-canada-allowed-to-push-back-exportstart-date $/>$.

108

Letter from Sheri Young to National Energy Board Regulated Pipeline Companies (13 July 2017), re National Energy Board Filing Manual Revision 2017-01, NEB File Ad-GA-RG-GFR-FMAP 01, online: $<$ https://www.neb-one.gc.ca/bts/ctrg/gnnb/flngmnl/nbl/2017-07-13nbl-eng.pdf $>$.

National Energy Board, “Audit Reports,” online: <http://www.neb-one.gc.ca/sftnvrnmnt/cmplnc/rprts/ dt/index-eng.html>.

National Energy Board, "FAQs — Focused Audits" (30 November 2017), online: <http://www.nebone.gc.ca/bts/nws/fqs/ fcsddtsfq-eng.html $>$. 
improve their own management systems. This is the first time that the NEB has issued an IA making this type of request. ${ }^{11}$

\section{NEB NORTHEASTERN BRITISH COLUMBIA TOLLING DECISION}

In March 2017, the NEB launched a process to determine whether to hold an inquiry of the tolling methodologies and tariff provisions in regulated natural gas pipelines in Northeastern British Columbia. The process was launched to address the current lack of takeaway capacity in Northeast British Columbia, which has created a highly competitive environment between pipeline operators and led to disputes, particularly between Westcoast and NGTL. ${ }^{112}$

On 8 March 2018, the NEB issued a Letter Decision. In the decision, the NEB acknowledged the competitive landscape in Northeastern British Columbia but determined that an inquiry was not warranted and would "introduce undue uncertainty to the Northeast BC supply basin and may not effectively resolve these potential issues."

The NEB determined that cost causation and economic efficiency would need to be addressed, but that it would be best addressed in each company's upcoming individual toll applications. The NEB directed NGTL and Westcoast to file specific information with the Board with each company's respective 2019 final toll application. ${ }^{114}$

The Board also stated that it will consider revising its Filing Manual in order to ensure that issues relating to fair competition can be dealt with in individual tolling applications. ${ }^{115}$

\section{Climate Change and Greenhouse Gas Emissions}

\section{A. Alberta Carbon Competitiveness Regulation}

On 18 December 2017, the Alberta government released the long-awaited Carbon Competitiveness Incentive Regulation, ${ }^{116}$ which came into force 1 January 2018. The CCIR replaces the existing Specified Gas Emitters Regulation ${ }^{117}$ for the compliance year of 2018 and onwards. According to the Government of Alberta, it is expected to cut emissions by 20 million tonnes by 2020 and 50 million tonnes by $2030 .{ }^{118}$

111 National Energy Board, News Release, "NEB Issues Information Advisory to All Regulated Companies Based on Findings from New Audit Process" (16 November 2017), online: < https://www.newswire.ca/ news-releases/neb-issues-information-advisory-to-all-regulated-companies-based-on-findings-fromnew-audit-process-658029553.html>.

112 Letter from Sheri Young to Bernard Pelletier, Brian Troicuk \& Rachel Kolber (8 March 2018), re Examination to Determine Whether to Undertake an Inquiry of the Tolling Methodologies, Tariff Provisions and Competition in Northeast British Columbia, NEB File OF-Tolls-TollsGen-15 01, online: $<$ https://apps.neb-one.gc.ca/REGDOCS/File/Download/3490855>.

Ibid at 3 .

Ibid at $4-7$.

Ibid at 4 .

Supra note 2.

Alta Reg 139/2007 [SGER].

Alberta Environment and Natural Resources, "Carbon Competitiveness Incentive," online: <https:// www.alberta.ca/carbon-competitiveness-incentives.aspx $>$. 
In structure, the CCIR remains an intensity-based emissions regime that imposes a cap on specified gases measured in carbon dioxide equivalent $\left(\mathrm{CO}_{2} \mathrm{e}\right)$. Large emitters (and those that opt-in) must either reduce their emissions intensity below a prescribed level or otherwise achieve the prescribed level by "truing-up" through emission performance credits, emission offsets, fund credits, or a combination of them. Perhaps the most notable change is the CCIR's introduction of a product-based baseline to develop a facility's output-based allocation of permissible $\mathrm{CO}_{2} \mathrm{e}$, rather than the facility's historical emissions used under the SGER.

A summary of these changes is provided below.

\section{ELIGIBLE EMITTERS}

Like the SGER before it, the CCIR applies to any facility that has emitted 100,000 tonnes of $\mathrm{CO}_{2} \mathrm{e}$ in 2003 or any subsequent year.

Facilities that emit less than the 100,000 tonne annual threshold may apply to opt-in to the CCIR. Facilities qualify to opt-in under one of two circumstances. First, a facility may opt-in if it is in direct competition with another facility subject to the CCIR (that is, it is a "competitively impacted facility"). Secondly, a facility may opt-in if it can demonstrate that (1) it is in an emissions-intensive trade-exposed (EITE) sector, and (2) that it either emits over 50,000 tonnes of total regulated emissions per year, or is likely to do so in its second full year of commercial operation.

The EITE status of a sector is determined by a combination of that sector's emissions intensiveness and its trade exposure, the exact ratios for which are outlined in the CCIR. ${ }^{119}$ A full list of information requirements for an opt-in application can be found in the Standard for Establishing and Assigning Benchmarks policy document. ${ }^{120}$

Facilities that opted-in under the SGER are not automatically carried over under the CCIR, and must re-qualify to opt-in to the CCIR. As under the SGER, CCIR-regulated facilities that opt-in are subject to the compliance obligations of the CCIR instead of those under the Alberta carbon levy. ${ }^{121}$

\section{The MOVE TO A BENCHMARK-BASED APPROACH}

Under the CCIR, benchmarks are used to determine a facility's output-based allocation (OBA), which is the prescribed level that a facility must meet. A facility's OBA is determined by multiplying the actual quantity of products produced by the facility by the product's benchmark value, then adjusting the outcome to account for a facility's import of electricity, heat, or hydrogen. The facility's OBA is then compared to its Total Regulated Emissions (TRE), which is the sum of its direct emissions of specified gases.

120 Alberta, Standard for Establishing and Assigning Benchmarks V2.1 (Edmonton: Alberta Government, June 2018) at 10-11, online: <https:/www.alberta.ca/assets/documents/CCI-standard-establishingassigning-benchmarks.pdf $>$ [Benchmark Standard]. 
Unlike the SGER, which looked to the facility's historical emissions, benchmarks under the CCIR are set by product and are either "assigned" or "established." Established benchmarks are determined based on production-weighted average, best-in-class, or top quartile production methodologies, and are generally calculated based on 80 percent of production-weighted average. ${ }^{122}$ Where the production-weighted average approach results in a reduction requirement more stringent than the best performing facility in a sector, the emissions intensity of such a facility will typically become the basis for the "best-in-class" benchmark.

Assigned benchmarks differ from established benchmarks in that they are facility-specific rather than product-specific because, with a few notable exceptions, assigned benchmarks apply only to products that are produced at a single regulated facility. ${ }^{123}$ Assigned benchmarks are typically 80 percent of the production-weighted average of emissions for such a facility. ${ }^{124}$

However, benchmarks have also been assigned for products produced by more than a single regulated facility in certain areas of oil and gas (upgrading, natural gas processing, and natural gas transmission networks), fertilizer, and multi-product chemicals due to insufficient data or to difficulty in production metrics. Benchmark type may change from "assigned" to "established" once adequate data is available. ${ }^{125}$

Both assigned and established benchmarks that employ the production-weighted average methodology can be adjusted upwards to reduce the stringency of the reduction requirement. This adjustment can be made where the facility can demonstrate that it employs best in class technology or the best available technology that is economically achievable, or where it is in an EITE sector and compliance costs cause an operational vulnerability. ${ }^{126}$ An annual 1 percent tightening of the benchmarks is also expected. ${ }^{127}$

\section{OTHER NOTABLE CHANGES}

Compliance options that facilities may use to "true-up" their actual emissions against their OBA remain largely unchanged. However, emission performance credits and emission offsets generated by facilities will now expire. Those credits or offsets generated in or before 2014 will now expire in 2020, while those generated in 2015 or 2016 will expire in 2021. Credits generated in 2018 and beyond will expire after eight years. ${ }^{128}$ In addition, the CCIR imposes a 50 percent cap on the use of emission offsets and emission performance credits to "true-up" a facility's net emissions. The cap will grow to 55 percent and 60 percent in 2019 and 2020, respectively. ${ }^{129}$

Benchmark Standard, ibid at 26-27.

Ibid at 28-29.

Ibid.

Ibid.

Ibid at 32-33.

CCIR, supra note 2, Schedule 2.

Ibid, s 19

Ibid, s 19(5). 
The CCIR also imposes additional reporting. Emitters with emissions over one megatonne must complete quarterly compliance reporting in 2018, and all other regulated facilities will follow starting 31 March 2019.

Finally, on 21 December 2017, the Minister issued the Climate Change and Emissions Management Fund Credit Amount Order which sets the value of one fund credit at $\$ 30.00$ for $2018 .^{130}$

\section{B. Alberta Energy Regulator \\ DRAFT DIRECTIVES 60 AND 17 - REducing Methane Emissions}

On 24 April 2018, the Alberta Energy Regulator (AER) released Directive 060 - Draft: Upstream Petroleum Industry Flaring, Incinerating, and Venting ${ }^{131}$ and Draft Directive 017: Measurement Requirements for Oil and Gas Operations. ${ }^{132}$ The revisions to both existing directives are intended to introduce new requirements to reduce methane emissions.

Draft Directive 17 includes new methane emission reductions, quantification, reporting, record keeping, and includes new requirements for vent gas measurement and testing. Draft Directive 60 imposes new limits on flaring at gas plants, as well as new vent gas limits and fugitive emissions management requirements. Under Draft Directive 60, duty holders will also be required to prepare a Methane Reduction Retrofit Compliance Plan (MRRCP) starting 1 June 2019 that outlines how they will comply with the new equipment-specific vent gas limits. ${ }^{133}$

Feedback on the draft directives was accepted until 28 May 2018 via online form, email, or mail. ${ }^{134}$ The new limits and requirements set out in each directive are scheduled to come into effect at various times that are outlined in each directive.

\section{STATUS UPDATE: \\ Canada's Climate Change Plan}

In 2016, the federal government issued its plan to address climate change in the PanCanadian Framework on Clean Growth and Climate Change. ${ }^{135}$ This document, made in

130 Ministerial Order 58/2017, online: <https://www.alberta.ca/assets/documents/CCEMA-fund-creditministerial-order.PDF $>$.

131 Alberta Energy Regulator (April 2018), online: <https:/www.aer.ca/documents/directives/Directive 060 Draft.pdf $>$ [Draft Directive 60].

132 Alberta Energy Regulator (April 2018), online: <https://www.aer.ca/documents/directives/Draft Directive017.pdf $>$ [Draft Directive 17]. See Alberta Energy Regulator, "Bulletin 2018-09: Invitation for Feedback on Draft Requirements for Reducing Methane Emissions" (24 April 2018), online: $<$ https://aer.ca/documents/bulletins/Bulletin-2018-09.pdf $>$ [April 2018 Bulletin].

133 Supra note 131 at 77. In this section, "duty holder" means the holder of an approval under the Oil Sands Conservation Act, RSA 2000, c O-7 or, where the context so requires, the holder of a licence or approval under the Pipeline Act, RSA 2000, c P-15; or Oil and Gas Conservation Act, RSA 2000, c O-6; or the operator of a facility where a licence or approval is not required under the Oil and Gas Conservation Act.

134 April 2018 Bulletin, supra note 132.

135 Pan-Canadian Framework on Clean Growth and Climate Change: Canada's Plan to Address Climate Change and Grow the Economy (2016), online: <publications.gc.ca/collections/collection_2017/eccc/ En4-294-2016-eng.pdf $>$ [Climate Change Plan]. 
collaboration with the majority of provinces and all the territories, outlined commitments to reviewing progress on an annual basis to assess the effectiveness of climate actions towards greenhouse gas (GHG) reduction targets and building climate resilience. Since then the provinces and territories have taken various actions and positions regarding climate action.

In March 2018, the Office of the Auditor General of Canada (the Auditor General) released its report "Perspectives on Climate Change Action in Canada: A Collaborative Report from Auditors General" which summarized audit findings from reports of provincial audit offices and legislatures completed between November 2016 and March 2018. ${ }^{136}$ This report, which marked the first time the federal auditor completed a review of climate policy, generally concluded that federal and provincial targets will not likely be reached.

Some of the key findings of the Auditor General in his 2018 report were:

- the majority of provinces and territories (seven out of 12) did not have an overall target for the reduction of GHG emissions by 2020 ;

- of the provinces and territories with a target for GHG emissions reduction, only two were on track to meet that goal;

- the risks of climate change and adaptation plans have not been assessed or considered by most governments;

- $\quad$ coordination between governments on climate change is weak; and

- $\quad$ regular and timely progress reporting was an issue for some governments.

The Climate Change Plan sought to ensure that provinces and territories could choose to implement their own carbon pricing systems based on the particular needs of that province. If provinces opted out of making their own framework, or where their framework was insufficient, the federal Climate Change Plan would apply as a "backstop." Provinces had until 30 March 2018 to confirm whether or not they would choose the federal framework. ${ }^{137}$ At the time of writing, none of the provinces have opted into using the federal benchmark system for carbon pricing.

Scott Moe, the Premier of Saskatchewan, has expressed continual opposition to the federal plan and has challenged the same on the basis of unconstitutionality. On 25 April 2018, the province of Saskatchewan filed the following reference question at the Saskatchewan Court of Appeal: "The Greenhouse Gas Pollution Pricing Act was introduced into Parliament on

Canada, Office of the Auditor General (March 2018), online: <www.oag-bvg.gc.ca/internet/ English/parl_otp_201803_e_42883.html\#hd2h>.

137 Canada, Environment and Natural Resources, "Carbon Pricing: Regulatory Framework for the OutputBased Pricing System" (31 January 2018), online: <https://www.canada.ca/en/services/environment/ weather/climatechange/climate-action/pricing-carbon-pollution/output-based-pricing-system.html> . 
March 28, 2018 as Part 5 of Bill C-74. If enacted, will this Act be unconstitutional in whole or in part?" 138 At the time of writing, this matter has yet to be heard by the Court.

\section{AMENDMEnTS TO OnTARio's Cap and Trade Programs}

The Ministry of the Environment and Climate Change (MOECC) has amended The Cap and Trade Program, ${ }^{139}$ pursuant to the recently-signed Agreement on Harmonization and Integration of Cap and Trade Programs for Reducing Greenhouse Gas Emissions. ${ }^{140}$ The Agreement on Harmonization and subsequent amendments (together, the Amendments) harmonize Ontario's program with cap and trade programs in California and Quebec, and also clarify and codify fair and equitable treatment among participants. The Agreement and Amendments came into effect on 1 January 2018.

The centrepiece of the regulatory changes is the recognition of compliance instruments from California and Quebec within Ontario. ${ }^{141}$ Ontario is now the first of the three jurisdictions to enact this mutual recognition-type regulatory change, with California and Quebec expected to follow suit. The Amendments allow Ontario participants to buy and sell compliance instruments from any of the three jurisdictions, as well as use these compliance instruments to fulfill their compliance obligations within Ontario.

The Amendments also introduce a common price for compliance instruments between the three jurisdictions, rather than relying on daily exchange rates or prices under the present system. Holding limits have been increased to account for the combined annual caps in Ontario, Quebec, and California. Though purchase limits remain the same ( 25 percent of the total number of offered allowances for capped participants and 4 percent for market participants), these figures are now applied to the larger combined market of all three jurisdictions, effectively increasing purchase limits. The Amendments also allow participants with facilities across multiple jurisdictions to register in each jurisdiction, allowing them to meet their compliance obligations in each jurisdiction rather than remaining confined to a single jurisdiction under the current model.

In addition to the harmonization measures, the Amendments are aimed at improving program fairness and equitable treatment for participants. The MOECC will work to provide free-of-charge allowances for non-combustion-related emissions for voluntary participants, in order to match the similarly free-of-charge allowances voluntary participants currently

Government of Saskatchewan, News Release, "Province Challenging Federal Government's Ability to Impose a Carbon Tax" (25 April 2018), online: <https://www.saskatchewan.ca/government/news-andmedia/2018/April/25/carbon-tax-case $>$. See Bill C-74, An Act to implement certain provisions of the budget tabled in Parliament on February 27, 2018 and other measures, 1st Sess, 42nd Parl, 2015-16-1718 (assented to 21 June 2018), SC 2018, c 12. O Reg 144/16.

140 Office of the Premier of Ontario, Backgrounder, Agreement on the Harmonization and Integration of Cap-and-Trade Programs for Reducing Greenhouse Gas Emissions (22 September 2017), online: $<$ https://news.ontario.ca/opo/en/2017/09/agreement-on-the-harmonization-and-integration-of-cap-andtrade-programs-for-reducing-greenhouse-gas.html> [Agreement on Harmonization].

141 A compliance instrument refers to any allowance or credit issued as part of a cap and trade program. See Environmental Commissioner of Ontario, "Introduction to Cap and Trade in Ontario: Appendix A to the ECO’s Greenhouse Gas Progress Report 2016”(2016), online: <media.assets.eco.on.ca/web/2016/ 11/Appendix-A-Introduction-to-Cap-and-Trade-in-Ontario.pdf $>$. 
enjoy for combustion-related emissions. Similarly, the MOECC is considering providing free allowances to capped facilities in the Sarnia region to reflect free allowances provided for similar participants in other regions.

The MOECC has also amended the administration of the cap and trade program to promote efficiency and clarity. Participants must proactively submit verification reports demonstrating compliance with the program, rather than requiring that the MOECC request such information from participants. The deadlines for allowance transfers have been adjusted to allow capped facilities to use allowances that reflect production changes for compliance purposes. Similarly, deadlines for free allowance applications and voluntary participant registration have been moved to October 1 of each year to allow participants more time to finalize applications.

These developments suggest Ontario is moving into the next phase of its cap and trade program. The harmonization with California and Quebec was set as a goal in 2007, and its enactment suggests a more expansive scope and application of Ontario's program. Additionally, administrative changes suggest a more broad-strokes equitable treatment for all participants, as well as a revised administrative framework that is tailored toward transparency and participant convenience. These amendments are not the end goal of Ontario's cap and trade program, but rather represent the next major step in its evolution.

\section{ENVIRONMENTAL ISSUES AND IMPACT ASSESSMENT}

\section{A. Bill C-68: An ACt to AMEND the Fisheries ACT AND OTHER ACTS IN CONSEQUENCE, 2018}

As part of a broader framework of environmental and regulatory reform, the federal government introduced amendments to the Fisheries Act $^{142}$ (the Proposed Amendments) through Bill C-68, ${ }^{143}$ which received First Reading on 6 February 2018 and passed Second Reading on 16 April 2018. The Proposed Amendments broaden the protection and conservation of fish and fish habitats, and expand the scope of regulation of the same. While still subject to parliamentary review and debate, certain notable changes proposed in the Proposed Amendments are outlined below.

\section{BROADENING OF REGULATORY SCOPE}

The proposed changes reinstate certain concepts that existed in the Fisheries Act prior to November 2013, and expand the scope of regulation of fish and fish habitat. Under the current Fisheries Act, fish that are part of a commercial, recreational, or Aboriginal fishery are captured within the definition of fish habitat; however, the Proposed Amendments extend that definition to include any waters frequented by fish or upon which fish depend, subject to certain exceptions. ${ }^{144}$ This will likely result in more waterbodies being subject to federal regulatory jurisdiction. 


\section{DECISION-MAKING}

The Proposed Amendments also grant the Minister discretion to consider a wide range of factors when making decisions. These include the adverse effects a decision under the Fisheries Act may have on the rights of Indigenous peoples, as well as other factors such as the sustainability of fisheries; scientific information; community knowledge; social, economic and cultural factors; traditional Indigenous knowledge and cooperation with any government of a province and Indigenous governing body established under a land claims agreement. ${ }^{145}$ The Proposed Amendments further require the consideration of the cumulative effects on fish and fish habitat of carrying on the activity, work, or undertaking in combination with other activities that have or are being undertaken. ${ }^{146}$

\section{PROTECTION OF Fish AND Fish HaBitaT}

In addition to the steps taken to broaden the definition of fish habitat to include more Canadian waterbodies, the Proposed Amendments restore certain provisions from prior legislation. Under the prohibition of damage to fish or fish habitats, the Amendments propose to replace the current language of "serious harm" with the previous standard of "harmful alteration, disruption or destruction of fish habitat" (HADD). ${ }^{147}$ The Proposed Amendments do not propose any changes to the minimum and maximum fines for an offense under section 35(1), which will remain as currently outlined under section 40(1) of the Fisheries Act.

New to this version, the Proposed Amendments impose a broad prohibition against carrying on "any work, undertaking or activity, other than fishing, that results in the death of fish." 148 There are also new notification requirements for incidents that result in unauthorized HADD, and additional considerations for the Minister that account for the cumulative effects of works on fish and fish habitats. ${ }^{149}$ Additionally, under the prohibition against serious harm to fish, the Proposed Amendments carve out certain exceptions which include grandfathering provisions for existing section $35(2)(b)$ authorizations.

\section{INTRODUCTION OF HABITAT CREDITS}

In addition to the broadening of the protections afforded to fish and fish habitats, the Proposed Amendments introduce "habitat credits," which can be acquired by a proponent who carries out a conservation project within a fish habitat. These credits are intended to quantify the benefits of a conservation project that seeks to create, restore, or enhance a fish habitat. ${ }^{150}$

Proponents can use habitat credits to offset the adverse effects a project may have on fish or fish habitats. When entering into an arrangement for habitat credits, the Minister and the proponent must agree to, among other things, the unit of measure that would quantify the

Ibid, $\mathrm{cl} 21$, s 34.1(1)(d) of the Fisheries Act as it will be amended.

Ibid, $\mathrm{cl} 22$, s 35(1) of the Fisheries Act as it will be amended.

Ibid, cl 21, s 34.4(1) of the Fisheries Act as it will be amended.

Ibid, cl 25(6), ss 38(4.1), 34.1(1) of the Fisheries Act as it will be amended.

Ibid, $\mathrm{cl} 28, \mathrm{ss} 42.01,42.02(1)$ of the Fisheries Act as it will be amended. 
benefits of a conservation project, and critical details regarding the administration, management, and operation of the arrangement. ${ }^{151}$ Once the amount of habitat credits is settled, the Minister issues a certificate respecting the validity of the credits acquired.

Under the new section 42.02(1)(a), the Minister may establish a system for the creation, allocation, and management of habitat credits. As currently proposed, several components of the habitat credit system remain unclear (including whether habitat credits will be tradable). Like many elements of the Amendments, these components will likely be clarified in the regulations.

\section{UPDATED PERMIT REQUIREMENTS}

The Proposed Amendments will update the management of projects by enabling the Minister to make regulations regarding permits for "designated projects." Before the amended regulations are released, the scope of captured activities considered "designated projects" remains unclear. Under the Proposed Amendments, persons are prohibited from carrying on work, undertakings, or activities that are part of "designated projects," except in accordance with a permit. ${ }^{152}$ These new requirements are in addition to the requirements to obtain authorizations to undertake activities that cause HADD.

In addition to permits for "designated projects," the proposed amendments also allow the Minister to establish codes of practice, which may provide formal guidance for small routine projects. $^{153}$

\section{ENFORCEMENT FRAMEWORK}

With respect to offences, the Proposed Amendments introduce Alternative Measures Agreements (AMAs). AMAs are measures, other than judicial proceedings, which may be used to deal with a person alleged to have committed an offence under the Fisheries Act. ${ }^{154}$ An alleged offender who has been charged with an offence under the Fisheries Act may apply to participate in the use of an AMA, if doing so is consistent with the purpose of the Fisheries Act and various conditions are met, such as the Attorney General being satisfied the measures are appropriate, taking into account the alleged offender's history of compliance and acceptance of responsibility. ${ }^{155}$ The Minister is granted broad regulationmaking power on the terms and conditions that may be included in AMAs and their effects on the alleged offender. ${ }^{156}$

\section{INDIGENOUS INTEGRATION}

The Proposed Amendments take steps to increase Indigenous peoples' role in project reviews, decision-making, and policy development. The proposed changes require the

Ibid, cl 28, s 42.02 of the Fisheries Act as it will be amended.

Ibid, cl 22(4), s 35(2)(f) of the Fisheries Act as it will be amended.

Ibid, cl 21, s 34.2(1) of the Fisheries Act as it will be amended.

Ibid, cl 47, s 86.1 of the Fisheries Act as it will be amended.

Ibid, cl 47, s 86.2(c)(ii) of the Fisheries Act as it will be amended.

Ibid, $\mathrm{cl} 47, \mathrm{~s} 86.95$ of the Fisheries Act as it will be amended. 
Minister to consider "any adverse effects" that a decision under the Fisheries Act may have on the rights of Indigenous peoples as well as any provided Indigenous traditional knowledge when making habitat decisions. ${ }^{157}$ Furthermore, in the event that a province or Indigenous governing body has a provision in force equivalent to certain provisions of the Proposed Amendments, the Minister under the proposed regime will have the discretion to declare those provisions inapplicable in a province or territory of an Indigenous governing body in which an agreement has been entered into. ${ }^{158}$

\section{CONCLUSION}

While the scope of protection under the Fisheries Act will be expanded, the approach to implementation will be left to the regulations. The content of those regulations will have a substantial impact on how development proceeds.

\section{B. Bill C-69: CANAdian ENERGy REgulator ACT}

Bill C- $69^{159}$ proposes an overhaul of various aspects of the current environmental assessment regime. If successful, the government has indicated its intention to bring Bill C69 into force in early $2019 .^{160}$

In relation to the NEB, Bill C-69 proposes the repeal of the National Energy Board Act ${ }^{161}$ and the enactment of the Canadian Energy Regulator Act (CERA). According to the federal government, the proposed changes are aimed at restoring investor confidence, advancing reconciliation with Indigenous peoples, and offering greater certainty, more transparency, and enhanced participation by the public and Indigenous peoples. ${ }^{162}$

Overall, the CERA parallels the current regulatory regime under the NEBA in several areas, including pipeline traffic, tolls and tariffs; authorizations for the export of oil and gas; liabilities for unintended or uncontrolled releases; and a pipeline company's financial requirements. However, in each of these existing areas the considerations that the new Canadian Energy Regulator must consider have been significantly broadened. The more significant changes are outlined below.

\section{NEW CORPORATE STRUCTURE}

The CERA would establish the Canadian Energy Regulator (the Regulator) to replace the NEB. The Regulator will be an agent of the Crown and its head office will be in Calgary. ${ }^{163}$

Ibid, cl 3, s 2.4 of the Fisheries Act as it will be amended.

Ibid, cl 6, s 4.2(1) of the Fisheries Act as it will be amended.

Supra note 1.

Government of Canada, "Consultation Paper on Approach to Revising the Project List" (2 June 2018), online: <https://www.canada.ca/en/services/environment/conservation/assessments/environmental-re views/environmental-assessment-processes/consultation-paper-approach.html $>$ [Government of Canada, "Consultation Paper"].

Supra note 10.

Bill C-69, supra note 1, Preamble.

Ibid, cl 10, s 10 of the Canadian Energy Regulator Act as it will be enacted. 
The Regulator will have a five to nine member board of directors responsible for the governance of the Regulator. At least one of the directors must be an Indigenous person. ${ }^{164}$

The Regulator will also have a Commission of up to seven full-time commissioners - one of the commissioners must be an Indigenous person. The Regulator may also have an additional complement of part-time commissioners. ${ }^{165}$ A commissioner is not eligible to be a director of the Regulator. ${ }^{166}$

\section{REGULATOR'S JURISDICTION}

The Regulator's jurisdiction over energy projects and its mandate largely continues the NEB's current jurisdiction and mandate. ${ }^{167}$

However, impact assessments for projects that are "designated" pursuant to the proposed Impact Assessment Act (IAA) would be conducted pursuant to the IAA (described in detail below at Part C). ${ }^{168}$ The $I A A$ will require the Minister to refer the impact assessment of a designated project to a review panel if the designated project includes physical activities regulated under the CERA. ${ }^{169}$ In this circumstance, at least one member of the review panel must be a commissioner under the CERA. ${ }^{170}$

\section{BROADER “Public INTEREST" CONSIDERATIONS FOR PIPELINE CERTIFICATES}

When considering whether to make a recommendation to the Minister on an application for a pipeline certificate, the CERA expands the range of factors the Commission must consider in its public interest determination. Additional factors the Commission must consider include:

- $\quad$ environmental effects (including cumulative environmental effects);

- $\quad$ safety and security of persons and the protection of property and the environment;

- $\quad$ health, social, and economic effects;

- $\quad$ interests and concerns of Indigenous peoples; and

- $\quad$ effects on the rights of Indigenous peoples. ${ }^{171}$

The CERA requires the Commission to consider these factors in light of Indigenous traditional knowledge provided to the Commission and in light of scientific information and 
data. CERA also requires the Commission to consider these factors when deciding whether to issue a certificate for a power line or an authorization for an offshore renewable energy project or offshore power line. ${ }^{172}$

\section{LEGISLATED TIMELINES}

Similar to the existing regime, the CERA establishes legislated maximum timelines for the review of projects that are not also designated projects under the IAA. In some instances, such as for an application requesting a pipeline exemption order, the maximum timeline for review is shorter than current $N E B A$ timelines. ${ }^{173}$

CERA timelines are subject to the discretion of the Lead Commissioner of the Regulator to specify "excluded periods" and also subject to the discretion of the Minister to grant "extensions," which could extend the timelines for consideration of applications. ${ }^{174}$

The current regime under the NEBA describes the discretion of the NEB to exclude periods in the calculation of timelines. The Lead Commissioner's discretion under the CERA to exclude periods will be defined by regulation.

\section{INCREASED INDIGENOUS AND PUBLIC PARTICIPATION}

Specific provisions of the CERA are directed at increasing the involvement of Indigenous peoples in the regulation of Canadian energy projects. Specifically:

- the Commission must consider the interests and concerns of Indigenous peoples and the effects of a project on the rights of Indigenous peoples in its public interest determinations;

- the Commission must consider the adverse effects that its decisions, orders or recommendations may have on Indigenous peoples in its decision-making; ${ }^{175}$ and

- the consent of a band council must be obtained before a company uses or takes possession of reserve lands to construct a pipeline or engage in activities that are required to determine pipeline routing. ${ }^{176}$

The CERA further authorizes the Regulator to establish committees or programs to enhance Indigenous involvement in pipelines, power lines, offshore energy projects, and abandoned pipelines, and in matters related to the safety, security, and protection of persons, property, and the environment. ${ }^{177}$

Ibid.

Ibid, ss 214(3), 262(2), 298(5) of the Canadian Energy Regulator Act as it will be enacted. Ibid, ss 42, 183(5)-(6), 214, 262 of the Canadian Energy Regulator Act as it will be enacted. Ibid, s 56 of the Canadian Energy Regulator Act as it will be enacted.

Ibid, s 317 of the Canadian Energy Regulator Act as it will be enacted. See also the new transparency measures under the Extractive Sector Transparency Measures Act, SC 2014, c 39, s 376 [ESTMA] that now capture payments made to Indigenous governments at Part V.B of this article.

Bill C-69, supra note 1, cl 10, s 57 of the Canadian Energy Regulator Act as it will be enacted. 
The CERA also authorizes the Minister to enter arrangements with any Indigenous or nonIndigenous governing bodies for carrying out the purposes of the CERA, if authorized by regulation to do so. ${ }^{178}$

In line with the federal government's stated goals of transparency and enhanced participation by the public and Indigenous peoples, the CERA requires that all decisions of the Commission (except decisions related to the Regulator's internal administration) be written, and that all such decisions and reasons be made public. ${ }^{179}$ Of particular note, the new regulatory regime will eliminate the "directly affected" standing test currently found in the NEBA. CERA permits any member of the public to make representations to the Commission on a certification application for a pipeline. ${ }^{180}$

\section{TRANSITIONAL PROVISIONS}

The NEBA will continue to govern until the CERA comes into force. Even after the CERA comes into force, the NEBA will govern in certain respects. For example, applications that are pending before the NEB immediately before the CERA comes into force will continue to be processed in accordance with the version of the NEBA that was in force prior to the coming into force of the CERA. ${ }^{181}$ The CERA will also include a provision to allow current members of the NEB to continue to hear and decide matters that were before the board member prior to the CERA coming into force, at the request of the Lead Commissioner. ${ }^{182}$

\section{Bill C-69: Impact Assessment ACT}

The IAA proposed as part of Bill C-69 enacts a move from environmental impact assessment to impact assessment more generally. This new approach will necessitate more comprehensive assessments to encompass the specific factors to be considered during assessment and to meet a new definition of public interest. However, the ultimate decision on whether to approve a proposed project will still rest with the Minister or the Governor in Council.

\section{NEW CORPorate STRUCTURE}

As written, Bill C-69 will repeal the current Canadian Environmental Assessment Act, 2012, ${ }^{183}$ and replace it with the IAA. Similarly, under the IAA the Canadian Environmental Assessment Agency (CEAA) will be replaced with the Impact Assessment Agency of Canada (the Agency).

The Agency will also assume an expanded role as the authority responsible for impact assessments for all designated projects, though joint review panels are provided for when the

Ibid, ss 74-78 of the Canadian Energy Regulator Act as it will be enacted.

Ibid, s 63 of the Canadian Energy Regulator Act as it will be enacted.

Ibid, s 183(3) of the Canadian Energy Regulator Act as it will be enacted.

Ibid, s 36 of the Canadian Energy Regulator Act as it will be enacted.

Ibid, s 37 of the Canadian Energy Regulator Act as it will be enacted.

SC 2012, c 19, s 52 [CEAA, 2012]. 
designated activity is regulated under the Nuclear Safety and Control Act ${ }^{184}$ or the proposed CERA. ${ }^{185}$

\section{BROADENED SCOPE OF EFFECTS}

The broader scope of impact assessments is reflected in the expanded scope of "effects," which the IAA defines as "changes to the environment or to health, social or economic conditions and the positive and negative consequences of these changes."

Additionally, the IAA requires assessment of "adverse direct or incidental effects," 187 which are effects directly linked or necessarily incidental to a federal authority's exercise of a power or duty that would permit the physical activity or designated project, or that are linked to federal financial assistance to enable an activity. ${ }^{188}$

\section{Continuation of the Designated Project ApProach}

The IAA retains the designated project model introduced under CEAA 2012, whereby activities listed on the Regulations Designating Physical Activities require approval. ${ }^{189}$ However, with the introduction of Bill C-69, the contents of the Project List have been opened to public consultation and the final contents will likely be unknown until early 2019 when the federal government intends Bill C-69 to come into force. ${ }^{190}$

The Minister may also designate an activity by request or of his or her own initiative, and must take into account any adverse impacts of the activity on Indigenous peoples of Canada when doing so. ${ }^{191}$

\section{A NEW DeFINITION OF THE PUBLIC INTEREST}

CEAA, 2012 required decision-makers to determine whether the project would cause significant adverse environmental effects, and whether they are justified in the circumstances. ${ }^{192}$ In contrast, under the $I A A$, the Minister or Governor in Council decides whether the activity is in the public interest. In making this decision, they must consider the following factors:

- the extent to which the designated project contributes to sustainability;

- the extent to which the effects, direct and indirect, within federal jurisdiction are adverse; 
- the implementation of the mitigation measures that the Minister or the Governor in Council considers appropriate;

- the impact the designated project may have on any Indigenous group and the rights of the Indigenous peoples of Canada recognized and affirmed by section 35 of the Constitution Act, $1982 ;{ }^{193}$ and

- the extent to which the effects of the designated project hinder or contribute to the Government of Canada's ability to meet its environmental obligations and its commitments on climate change. ${ }^{194}$

\section{NeW Project PathWAys AND Timelines}

\section{a. Planning Stage}

The steps along the impact assessment pathway remain largely the same. However, perhaps the most notable change is the introduction of a Planning Stage, which places greater emphasis on pre-application consultation and setting the scope for the regulatory process at the outset. ${ }^{195}$

The Planning Stage begins when the proponent submits a project description to the Agency. ${ }^{196}$ During this phase, the Agency will offer consultation to any jurisdiction with powers related to the activity and any Indigenous group that may be affected by the carrying out of the designated project, and will establish opportunity for public comment. ${ }^{197}$

Before the conclusion of the Planning Stage, the Minister may make an order directing the Agency not to continue the impact assessment if the Minister is of the opinion that it is clear that the project would cause unacceptable effects, or if a federal authority advises that it will not exercise a power that must be exercised for the project to be carried out. ${ }^{198}$

\section{b. Decision to Require an Impact Assessment}

At the end of the Planning Stage, the Agency will give the proponent a summary of relevant issues gathered through the planning phase. ${ }^{199}$ In return, the proponent must provide the Agency with a detailed notice of how it intends to address the issues and a detailed project description. ${ }^{200}$

Upon receiving all necessary information, the Agency will decide whether an impact assessment is required. In doing so, the $I A A$ requires that the Agency consider: 
- the possibility of adverse effects within federal jurisdictions, or adverse direct or incidental effects;

- $\quad$ any adverse impacts on the rights of Indigenous peoples;

- $\quad$ any comments received from the public;

- $\quad$ any relevant regional or strategic assessments;

- $\quad$ any study prepared by a jurisdiction; and

- $\quad$ any other factor that the Agency considers relevant. ${ }^{201}$

Upon deciding that an impact assessment is required, the Agency must post a notice of commencement to its website that outlines the studies and any documents required for the Agency to conduct the impact assessment. The time between the Agency's receipt of the project description from the Proponent and the notice of commencement is not to exceed 180 days, though the timeline may be extended by the Minister. ${ }^{202}$

c. Impact Assessment

Once a notice of commencement is posted, the proponent has three years to file the information required in the notice. ${ }^{203}$

Section 22 of the IAA sets out a number of notable — and mandatory - factors that must be considered as part of any impact assessment, some of which include:

- the effects of the project, including the effects of malfunctions or accidents and cumulative effects from the designated project in connection with other physical activities that have been or will be carried out;

- the impact the designated project may have on any Indigenous group and their Aboriginal rights;

- $\quad$ alternative means of carrying out the project that are technically and economically feasible, including through best available control technology;

- $\quad$ alternatives to the project;

- traditional knowledge of Indigenous peoples provided with respect to the designated project; 
- the extent to which the effects of the designated project affect Canada's environmental obligations and commitments to climate change;

- $\quad$ considerations related to Indigenous cultures raised by the project;

- $\quad$ community knowledge provided with respect to the project;

- $\quad$ comments from the public regarding the project;

- $\quad$ comments from a jurisdiction received at the planning stage;

- $\quad$ any assessment, study, or plan that is conducted by, or on behalf of, an Indigenous governing body or a jurisdiction; and

- the intersection of sex and gender with other identity factors. ${ }^{204}$

Where the Agency conducts the impact assessment, a draft report setting out the likely effects of the designated project must be posted for a period of public comment. ${ }^{205}$

\section{d. Review Panels, Joint Review Panels, and Substitution}

After considering the extent to which the effects within federal jurisdiction may be adverse, public concerns regarding those effects, and opportunities to cooperate with any jurisdiction with power to assess the environmental effects, the Minister may refer an impact assessment to a review panel or joint review panel within 45 days from the notice of commencement. ${ }^{206}$

The Minister must refer an impact assessment of a designated project to a joint review panel if the activity is regulated under the Nuclear Safety and Control Act ${ }^{207}$ or the proposed $C E R A{ }^{208}$ The $I A A$ also allows the Minister to substitute the process of another jurisdiction that has powers, duties, or functions in relation to the assessment of the effects of a designated project, but only if that process can assess all the factors listed in section 22 (above) and meets additional requirements set out in section 33, including participation by Indigenous groups and the public. ${ }^{209}$

Assessments conducted by the Agency may take up to 300 days, while an assessment under a review panel or joint review panel may take up to 600 days. ${ }^{210}$ Both timelines may be extended at the discretion of the Minister or the Governor in Council. ${ }^{211}$

Ibid, s 22 of the Impact Assessment Act as it will be enacted. Ibid, s 28 of the Impact Assessment Act as it will be enacted. Ibid, s 36 of the Impact Assessment Act as it will be enacted. Supra note 184.

Bill C-69, supra note 1, cl 1, s 43 of the Impact Assessment Act as it will be enacted.

Ibid, ss 22, 33 of the Impact Assessment Act as it will be enacted.

Ibid, ss 28, 37 of the Impact Assessment Act as it will be enacted.

Ibid, s 65 of the Impact Assessment Act as it will be enacted. 


\section{e. Decision-Making}

Where the impact assessment was conducted by the Agency, the Minister must make a decision on whether the activity is in the public interest or may refer the decision to the Governor in Council. ${ }^{212} \mathrm{~A}$ decision statement is required within 30 days. ${ }^{213}$ Where the impact assessment was conducted by a review panel or joint review panel, the public interest determination is made by the Governor in Council and a decision must be posted within 90 days. $^{214}$

Under the $I A A$, the Minister or Governor in Council must take public interest into account when making their decision, utilizing the same factors as set out above at section IV.C.5.

A decision statement must include the determination, any conditions related to the decision, and the time in which the proponent must carry out the activity. ${ }^{215}$

\section{CONCLUSION}

The new assessment regime under the IAA has the potential to complicate federal assessments and overwhelm the assessment process. The IAA will result in a broader scope of factors being assessed in a greater number of activity types, and will increase Indigenous and public participation in the assessment process through mandated consultation and new participant funding. This larger scope of assessment is accompanied by legislated timelines for each step that are the same or shorter than under the CEAA, 2012. The scope of the Project List also remains to be seen. Careful planning, management, and tightly drafted regulations and guidance documents will be necessary to achieve an efficient and effective regime.

\section{BiLl C-69: CANAdian NAVIGABLE WATERS ACT}

Bill C-69 introduces the proposed Canadian Navigable Waters Act (CNWA), which will reverse many of the changes introduced in the 2012 amendments to the Navigation Protection Act. ${ }^{216}$ As written, the proposed CNWA will expand the scope of navigable waters subject to regulation and increase the Minister's powers related to protecting those waters from unapproved obstructions.

\section{SCOPE OF NAVIGABLE WATERS}

The proposed CNWA would retain the schedule of navigable waters established under the NPA and also introduce a new statutory definition of "navigable waters":

[A] body of water, including a canal or any other body of water created or altered as a result of the construction of any work, that is used or where there is a reasonable likelihood that it will be used by vessels, 
in full or in part, for any part of the year as a means of transport or travel for commercial or recreational purposes, or as a means of transport or travel for Indigenous peoples of Canada exercising rights recognized and affirmed by section 35 of the Constitution Act, 1982, and

(a) there is public access, by land or by water;

(b) there is no such public access but there are two or more riparian owners; or

(c) Her Majesty in right of Canada or a province is the only riparian owner. ${ }^{217}$

This definition is more comprehensive than the common law test of navigability used in the past, which considered whether a waterway is, in fact, navigable, its use for public navigation, its historical use, and whether there was a reasonable likelihood of public use as an aqueous highway. ${ }^{218}$

\section{REGULATED WORKS}

Regulation of works within navigable waters will depend on whether the work is "minor" or "major," each to be defined by a schedule to the CNWA. At the time of writing, the contents of the schedule are not yet known. The CNWA also provides an application process for works that are not on either schedule but occur on a navigable water.

An owner of a minor work in, over, under, through, or across any navigable water may proceed without Ministerial approval, so long as it is conducted in accordance with the CNWA and its regulations. ${ }^{219}$ An owner of a major work in any navigable water or the owner of any other works (other than minor works) in a navigable water that is listed in a schedule to the CNWA must apply for Ministerial approval. ${ }^{220}$ In determining whether to issue an approval for a proposed work, the Minister must consider, among other things:

- the impact of the proposed work on navigation, both by itself and in combination with other works;

- $\quad$ traditional Indigenous knowledge provided to the Minister;

- $\quad$ public comments; and

- the owner's compliance record..$^{221}$

Bill C-69, supra note 1, cl 47(3), s 2 of the Canadian Navigable Waters Act as it will be enacted. Transport Canada, "Fact Sheet \#5: Determining Navigability" (October 2016), online: <https://www. canada.ca/content/dam/themes/environment/conservation/environmental-reviews/navigationprotection/Fact_sheet_5_Determining_navigability.pdf $>$. Bill C-69, supra note $\overline{1}, \bar{c}$ l 49, s 4 of the Canadian Navigable Waters Act as it will be enacted. Ibid, s 5 of the Canadian Navigable Waters Act as it will be enacted. Ibid, s 7(7) of the Canadian Navigable Waters Act as it will be enacted. 
In addition to the above, section 2.3 of the CNWA requires the Minister to consider any adverse impacts on Indigenous peoples of Canada that may result from any decision made under the CNWA. ${ }^{222}$

Owners of a proposed work that is neither a major work nor a minor work, and that is proposed in a navigable water not listed on the schedule, may choose whether to apply to the Minister or engage in a public notice process. ${ }^{223}$

\section{Ministerial POWERS AND ENFORCEMENT MEASURES}

The Minister may add waters to the schedule of navigable waters under the proposed CNWA after considering factors that include the physical characteristics of the navigable water, its connections to other navigable waters, and its past, current, or anticipated use as a navigable water by any person or by Indigenous peoples of Canada in exercise of their rights under section 35 of the Constitution Act, 1982. ${ }^{224}$

The Minister's enforcement powers are expanded under the proposed CNWA. If a person fails to comply with an order, the Minister "may do any thing with respect to the work" in the navigable water that he or she considers appropriate. ${ }^{225}$ The proposed CNWA also expands the Minister's ability to issue orders to persons who dump fill into navigable waters without, or in violation of, Ministerial approval.

Penalties for violating designated provisions of the CNWA are increased up to a maximum of $\$ 50,000$ (from $\$ 5,000$ ) for an individual and up to a maximum of $\$ 250,000$ (from $\$ 40,000)$ "in any other case." ${ }^{226}$ Contraventions of other provisions of the CNWA would be offences under the Act, and may be punished on summary conviction:

- for an individual, a fine of not more than $\$ 100,000$ for their first offence, and a fine of not more than $\$ 200,000$ or a term of not more than six months' imprisonment for subsequent offences, or both; or

- for a corporation, a fine of not more than $\$ 500,000$ for its first offence, and a fine of not more than $\$ 1,000,000$ for subsequent offences. ${ }^{227}$

The current maximum penalties are $\$ 50,000$, or a term of not more than six months' imprisonment, or both for all offences and all offenders.

The limitation period for violations is also increased from six months under the NPA to two years under the CNWA, and the limitation period for offences under the CNWA is set at five years from the date on which a designated person becomes aware of the acts that constitute the offence. ${ }^{228}$ 


\section{E. WOODLAND CARIBOU RECOVERY STRATEGY: Alberta's Draft Woodland Caribou Range Plan}

It was 2017 that marked the final year for provinces and territories to comply with their legal obligation to produce an adequate range plan to protect critical habitat for the boreal woodland caribou. Under the Species at Risk Act, ${ }^{229}$ which seeks to prevent extirpation or extinction of wildlife species, the Minister of Environment and Climate Change Canada (the Minister) is obliged to prepare a recovery strategy for certain wildlife species, including the woodland caribou. ${ }^{230}$ The federal recovery strategy was issued in 2012 , followed by the southern mountain recovery strategy (collectively, the Recovery Strategy). However, due to the provincial and territorial jurisdiction over the management of lands, resources, and wildlife within the ranges, the responsibility for ensuring protection of woodland caribou habitat largely falls to the provinces and territories.

Following the issuance of the Recovery Strategy, the provinces and territories were given five years to develop range plans for woodland caribou within their respective jurisdictions. In the event that provincial or territorial laws are found not to effectively protect the caribou species or its habitat, SARA provides for measures allowing the federal government to take action.

In December 2017, the Government of Alberta published the Draft Provincial Woodland Caribou Range Plan, describing the province's actions towards meeting caribou conservation and recovery goals and objectives. ${ }^{231}$ The Draft Plan contemplates further consultation and development of range plans with "range-specific details" for local populations of caribou. While the Draft Plan is subject to change as it moves through phases of public engagement prior to its final release, certain elements that may be of interest to proponents of the energy industry are highlighted below.

\section{Managing to 65 Percent Undisturbed Habitat}

The Draft Plan references options for managing towards 65 percent undisturbed habitat and calls for Integrated Land Management, which is a strategic, planned approach to restore, manage, and reduce the human footprint on the landscape. The Draft Plan calls for the creation of a Habitat Restoration Committee and working groups which will include industry, to develop operational restoration plans. ${ }^{232}$ The Draft Plan highlights restoration and associated considerations for seismic lines, geophysical exploration, and pipelines.

\section{MANAGEMENT OF ACCESS}

In the context of caribou range planning, the Draft Plan proposes to remove redundant roads in an effort to optimize road networks and reduce overall disturbance to the habitat of

\footnotetext{
229 SC 2002, c 29 [SARA].

$230 \quad$ Ibid, s $37(1)$, Schedule 1.

231 Government of Alberta, Draft Provincial Woodland Caribou Range Plan (Edmonton: Alberta Government, 2017), online: $<$ https://open.alberta.ca/dataset/932d6c22-a32a-4b4e-a3f5-cb2703c53280/ resource/3fc3f63a-0924-44d0-b178-82da34db1f37/download/draft-caribourangeplanandappendicesdec2017.pdf $>$ [Draft Plan]. 
the woodland caribou. ${ }^{233}$ To do this, the government is planning on conducting coordinated access management planning through Regional Access Management Plans (RAMP). These plans are to be created by the energy and forest industries and will have to be reviewed and approved by Alberta Environment and Parks. The goal of RAMP is to foster cooperation between land users to create shared road systems. The Draft Plan indicates that applications for permanent individual sector roads will not be approved without a "strong rationale."234 Pipelines and power lines that do not share common corridors with approved access within the regional access plan will be required to restore surface footprint to be on a trajectory to caribou habitat. ${ }^{235}$ Additionally, emphasis is placed on appended development, completing the majority of development within 200 metres of an optimized road network in order to minimize levels of disturbance. ${ }^{236}$

\section{MANAGEMENT OF ENERGY ACTIVITY}

\section{a. Sale of New Energy Leases}

Since 2015, the Alberta government has restricted leasing new tenure within caribou ranges. The Draft Plan proposes to maintain the current restriction on new leases until a range-specific analysis is completed. The government has indicated that future land sales within ranges will likely be evaluated based on the current level of disturbance, the expected lifespan of existing disturbances, the expected lifespan of proposed disturbances, the projected level and type of disturbances to develop resources, and caribou habitat and population health information. ${ }^{237}$

\section{b. Energy Development Requirements}

The Draft Plan proposes a multi-sectoral scheme for approving the development of industry projects within caribou ranges. This would include coordination between the ministries of Energy, Agriculture, and Forestry for making approval decisions in support of caribou habitat restoration. This idea is still in the conceptual phase, but will likely involve the establishment of critical habitat priority zones and the consideration of project approval within a broader, cumulative context. ${ }^{238}$

\section{CONCLUSION}

In the coming months, the federal government will determine whether the actions taken by the government of Alberta will effectively protect the woodland caribou in compliance with SARA, the federal Action Plan, and the federal Recovery Strategy. In the event that the federal government is not satisfied with Alberta's plan, measures may be taken to ensure protection for the woodland caribou. 
At the time of writing, the Alberta range plan remains in its draft form. As the Draft Plan moves through the engagement process, stakeholders can make their comments known to the government of Alberta regarding range-specific details before the final plan is released.

\section{F. ONTARIO DEVELOPMENTS \\ 1. HUANG V. FRASER HILLARY'S LIMITED ${ }^{239}$}

In Huang, the Ontario Superior Court of Justice confirmed that section 99 of the Ontario Environmental Protection $\mathrm{Act}^{240}$ provides a cause of action for damages from contamination that occurred before the section came into force in 1985. Huang also suggests that the statutory cause of action created in section 99 of the EPA is a stronger tool than the common law for plaintiffs "without any requirement of intent, fault, duty of care, or foreseeability."241

After discovering contamination on two of his properties from an adjacent dry cleaning business, Huang began an action against both the dry cleaner, Fraser Hillary's Limited (FHL), and its president and sole shareholder, Mr. Hillary. Section 99 of the EPA came into force in 1985, and provides for the recovery of any loss or damage resulting from the spill of a pollutant from the owner of the pollutant and the person having control of the pollutant.

The Court made three key findings in respect of the application of section 99 to the contamination occurring between 1960 and 1974 (that is, the period in which the spills were known to have occurred):

1. Section 99 provides for a right to compensation for a loss or damage incurred as a result of the spills and therefore does not constitute a retrospective application of the law in this case. A law is not retrospective if it gives effect only to prior facts in determining future rights and liabilities, but "does not change anything done in the past." 242

2. In the alternative, if section 99 does apply retrospectively, then the presumption against retrospectivity is rebutted because section 99(2) is intended to protect the public and not to punish. ${ }^{243}$

3. Even if section 99(2) punishes polluters, the Court held that the legislature intended for section 99 to apply to pre-1985 spills, as the remedy is not expressly restricted to spills occurring after this section of the EPA came into force. ${ }^{244}$

The Court found FHL liable to Huang under section 99(2) of the EPA as the owner and person having control of the pollutant immediately before the first discharge and awarded $\$ 1,632,500$ for remediation costs and $\$ 201,726.21$ for expert costs.

This decision was upheld on appeal. 


\section{HAMILTON BEACH BRANDS CANADA INC. V. ONTARIO (ENVIRONMENT AND CLIMATE CHANGE) ${ }^{245}$}

Hamilton Beach addressed the jurisdiction of the Director of the Ministry of the Environment and Climate Change (MOECC) to issue orders pursuant to section 18 of the EPA. The Director had issued an order under section 18 of the EPA to a number of parties (collectively, the Orderees) as persons who own or owned, or who have or had management or control, of a property located in Picton, Ontario (the Property). The MOECC discovered several metal drums containing volatile organic compounds buried on the Property, and further testing confirmed the contamination of the property and the migration of that contamination to nearby residential, commercial, and industrial properties.

Section 18 of the EPA provides the Director the authority to order a wide range of remediation and monitoring activities in relation to an undertaking or a specific property. The Director may make such an order if he or she believes it is necessary to prevent or reduce the risk of a contaminant discharge stemming from the undertaking or property, or to prevent, decrease, or eliminate an adverse effect that may result from a contaminant. This is a no-fault provision and an order can be issued to innocent landowners and tenants.

The Director's order required the Orderees to delineate the migrated contamination. The Orderees appealed the order to the Environmental Review Tribunal (ERT), arguing that the Director lacked the jurisdiction to make the order on three specific grounds:

1. The adverse effect must be a future event or circumstance, rather than an existing adverse effect (given that section 18 is prospective and preventative);

2. the adverse effect must be related to the potential off-site migration of a contaminant that is on an orderee's property at the time the order is made; and

3. because section 18 is an owner-based, rather than fault-based, provision, the order may require work only on-site but not off-site, to address the risk of an adverse effect.

The ERT rejected all three of the Orderees' arguments. Both the first and second grounds of appeal were rejected in favour of a more harmonious reading of section 18 and the EPA as a whole. The ERT found that an adverse effect is not limited to a future event or circumstance, and may include existing and ongoing adverse effects, given that contamination is "frequently an ongoing situation and not a single or static event or circumstance." 246 Similarly, the Director's jurisdiction is not limited to potential contamination on the property at the time of the order as such an interpretation is "contrary to the reality that contamination migrates" ${ }^{\prime 247}$ and would curtail the Director's jurisdiction in a manner that is contrary to the intention of the Legislature. On the third ground, the ERT 
found that "it would simply make no sense" to restrict an order to the boundaries of a particular property while ignoring the impact of the adverse effect itself. ${ }^{248}$

\section{WIGGINS V. ONTARIO (MINISTRY OF THE ENVIRONMENT AND CLIMATE CHANGE) $)^{249}$}

Wiggins is the first appeal to the ERT to successfully demonstrate that a renewable energy project posed a risk to human health, resulting in the revocation of a renewable energy approval (REA). In coming to its decision, the ERT explored the process of determining what constitutes a risk to human health, and determined that the interactions between a proposed project and existing infrastructure or developments should be included in its considerations.

The appeal involved an approval for Fairview Wind Incorporated (Fairview) to install eight wind turbines in Simcoe County, Ontario. Among the parties to appeal this approval were two aerodromes near the proposed turbine site, Clearview Field (Clearview) and the Collingwood Regional Airport (CRA). Clearview and the CRA argued that the wind farm made it more likely that pilots would crash their airplanes into wind turbines, and therefore posed a serious risk to human health.

Pursuant to section 145.2.1(2) of the EPA, the appellants bore the burden of proving on a balance of probabilities either serious harm to human health (the Health Test), or that serious and irreversible harm to plant or animal life or the natural environment will result from the project. ${ }^{250}$ The ERT came to several conclusions regarding the Health Test, including:

- appellants do not need to prove that the proposed project is the sole cause of the harm, as proof of combined or synergistic harm will meet the test. ${ }^{251}$ Similarly, the harm may be cause directly or indirectly, so long as it does somehow flow frm the project; and

- the Health Test does not require a quantitative risk assessment, nor is a quantitative test inherently preferable to a qualitative risk assessment. The most relevant issue is whether there is sufficient evidence to support a claim. ${ }^{252}$

The ERT further noted that it must evaluate mitigation measures based on feasibility and the likelihood that they would reduce harm. ${ }^{253}$ In this case, the ERT also looked to aviation safety requirements and found that the required buffer zones could not exist if wind turbines were built on the proposed site. Looking at the human factor, the ERT found that pilots using the aerodromes (many of whom were recreational rather than professional pilots) could not be expected to consistently and without fail execute the maneuvers necessary to avoid

\footnotetext{
$248 \quad$ Ibid at para 92.

249 (7 October 2016), 16-036, online: Ont ERT < www.ert.gov.on.ca/files/201610/00000300-GBT33A069 OO026-GJI58753180026.pdf $>$ [Wiggins].

Ibid at paras 94-95.

Ibid at para 95.

Ibid at para 111

Ibid at para 99.
} 
colliding with wind turbines during takeoff and landing, some of which would be seconds away from some flight paths.

The ERT determined that Fairview's proposed mitigation measures were not under Fairview's control nor easily feasible. As a result, it held that the proposed mitigation would not significantly reduce the likelihood of harm, and the Appellants had therefore established that serious harm to human health would result from the project. ${ }^{254}$ Based on this finding, the ERT revoked Fairview's REA.

\section{G. BRITISH COLUMBIA LEgislative UPDATES}

\section{Potential British Columbia Species At Risk Act}

It appears likely that British Columbia will see the introduction and implementation of species at risk legislation under British Columbia's New Democrat provincial government. On 6 November 2017, British Columbia Green Party member Andrew Weaver tabled Private Member's Bill M 208-2017, which reintroduced the Endangered Species Act, 2017 from February. ${ }^{255}$ This bill builds on and incorporates language from existing legislation in other jurisdictions, including the Ontario Endangered Species Act, 2007, ${ }^{256}$ the United States Federal Endangered Species Act of $1973,{ }^{257}$ and species at risk legislation that the British Columbia New Democratic Party tabled in 2011..$^{258}$

While the Bill is a private member's bill, British Columbia Premier John Horgan instructed the Minister of Environment and Climate Change Strategy, George Heyman, in his 18 July 2017 mandate letter to "[e]nact an endangered species law and harmonize other laws to ensure they are all working towards the goal of protecting our beautiful province."259 Additionally, this direction follows unsuccessful attempts in 2017 by the British Columbia Green Party and New Democratic Party to implement such legislation under the previous British Columbia Liberal government.

\section{ENVIRONMENTAL ASSESSMENT REVITALIZATION PROCESS}

British Columbia is preparing for reforms to the environmental assessment process, which intend to "ensure the legal rights of First Nations are respected and the public's expectation of a strong, transparent process is met." 260 The reforms follow the directions in Premier Horgan's British Columbia Environment Mandate Letter to undertake an Environmental

Ibid at para 175 .

Bill M 208-2017, Endangered Species Act, 2017, 2nd Sess, 41st Leg, British Columbia, 2017 (first reading 6 November 2017).

SO 2007 , c 6 .

16 USC \$1531 (1973).

Andrew Weaver, News Release, "Reintroducing Endangered Species Legislation for British Columbia" (6 November 2017), online: <www.andrewweavermla.ca/reintroducing-endangered-species-legislationbritish-columbia/>.

Letter from John Horgan, Premier, to George Heyman, Minister of Environment and Climate Change Strategy (18 July 2017), online: <https://www2.gov.bc.ca/assets/gov/government/ministries-organiza tions/premier-cabinet-mlas/minister-letter/heyman-mandate.pdf $>$ [BC Environment Mandate Letter]. British Columbia, Ministry of Environment and Climate Change Strategy, News Release, "Revitalizing B.C.'s Environmental Assessment Process" (7 March 2018), online: <https://news.gov.bc.ca/releases/ 2018ENV0009-000337> [BC Environment Release]. 
Assessment and Revitalization Process (the Revitalization Process). ${ }^{261}$ An independent Environmental Advisory Committee is leading the Revitalization Process throughout the spring and summer, and the government anticipates that it will introduce the changes in the fall of 2018.

The Revitalization Process is focused on achieving three key outcomes:

1. enhancing public confidence, transparency, and meaningful participation;

2. advancing reconciliation with First Nations; and

3. protecting the environment while supporting sustainable economic development.

Engagement includes First Nations Engagement Workshops (run in collaboration with the First Nations Energy and Mining Council) as well as direct engagement with key stakeholders including First Nations, industry, environmental NGOs, and local governments, among others. ${ }^{262}$

The reform to the environmental assessment process is prospective in nature, meaning that the current environmental assessment process will continue to apply to environmental assessments that are already underway.

\section{British Columbia CONTAMinAted Sites OMNiBus}

Effective 1 November 2017, the British Columbia provincial government introduced the most extensive changes to its Contaminated Sites Regulation ${ }^{263}$ since 1997. The changes include both the "Stage 10 Omnibus Amendments" (the Omnibus), which were approved by Ministerial Order on 31 October 2016, ${ }^{264}$ and the "Stage 11 Housekeeping Amendments," which corrected errors discovered in the Omnibus during the transitional period (collectively, the Contaminated Sites Amendments). ${ }^{265}$

The Contaminated Sites Amendments intend to modernize British Columbia's contaminated sites regime by updating the previously existing soil, water, and vapour standards. Both extensive and complex in nature, the Amendments update over 8,500 environmental quality standards.

The biggest changes are seen in soil, groundwater, and vapour standards. The Contaminated Sites Amendments update the numerical standards based on considerations related to the new British Columbia Environment and Climate Change groundwater model, new toxicology information, and new derivation protocols for environmental quality standards from environmental agencies around the world. They also add new toxicologybased soil and water standards for certain emerging contaminants (for example, 
perfluorinated compounds and specified additives to natural gas processing) based on the toxicity of the substance, its persistence in the environment, and its relevance to contaminated sites in British Columbia. ${ }^{266}$

The Contaminated Sites Amendments consolidate the 11 previously used schedules into four new schedules, organized by media: soil (Schedule 3.1), water (Schedule 3.2), vapour (Schedule 3.3), and sediment (Schedule 3.4). ${ }^{267}$

The CSR now distinguishes between two types of residential land use: high density and low density. This distinction was introduced to recognize that high-density land use presents different exposure scenarios to contaminants in soil. ${ }^{268}$

The Contaminated Sites Amendments also introduce two tiers of soil standards for Natural Wildlands and Reverted Wildlands. Natural Wildlands, which are identified in Schedule 2.1, include areas protected under statute for high conservation value. Reverted Wildlands, by contrast, are those lacking designated statutory protection, and encompass any other wildland (that is, land other than agricultural, commercial, industrial, urban park, or residential). ${ }^{269}$

The Contaminated Sites Amendments introduce a mandatory review of the environmental quality standards on a fixed term of every five years, to ensure that standards are kept up to date. $^{270}$

The changes are extensive and wide-reaching. Because the changes to standards are updated to reflect up-to-date knowledge, some standards have increased in stringency while others have relaxed.

\section{REVIEW OF BRITISH COLUMBIA'S Professional RELIANCE MODEL}

British Columbia is reviewing the professional reliance model that currently characterizes its regulatory regime in natural resources. The review, announced on 3 October 2017, consists of public feedback and participation, a review of current legislation governing qualified professionals (QPs) in the natural resources sector, and a review of best practices in other jurisdictions.

From 1 December 2017 to 19 January 2018, the government collected feedback from various stakeholders, including QPs, those in the private and public sector who use QPs, and the public.

British Columbia, Ministry of Environment, "Update on Contaminated Sites: Stage 10 (Omnibus) and Stage 11 (Housekeeping) Amendments to the Contaminated Sites Regulation" (31 October 2017) at 2, online: <https://www2.gov.bc.ca/assets/gov/environment/air-land-water/site-remediation/docs/lawsregulations-and-compliance/stage_10-11_amendment_update.pdf $>$. CSR, supra note 263 .

Ibid, s 1 .

Ibid.

Ibid, s 68 . 
The government expects to recommend:

- whether professional associations overseeing QPs employ best practices to protect the public interest;

- whether government oversight of professional associations is adequate; and

- $\quad$ conditions governing the involvement of QPs in government resource-management decisions, and the appropriate level of government oversight to assure the protection of public interests.

The government expects to release its final report in the spring of $2018 .^{271}$

The stated purposes of the review is to restore public trust and confidence in the government's oversight of its regulatory model. The professional reliance model in British Columbia has been the subject of criticism, particularly following the Mount Polley tailings dam failure in August 2014. Following the failure, the Auditor General released a report reviewing professional reliance in the mining context and recommending that the government establish policies and procedures for the oversight of QPs. ${ }^{272}$

The review may have wide-reaching implications for natural resource industries; under the current model, industry hires QPs to determine how to meet the natural resource management objectives set by government. Government then focuses on monitoring, compliance, and enforcement, but relies on QPs and their professional and ethical codes, and the oversight of professional associations governing the QPs. However, after announcing the review, the Minister of Environment and Climate Change Strategy, George Heyman, stated: "[i]t's certainly not the intent of the review to achieve a result where all of the monitoring activities by professionals would return to government or the cost associated with them would return to government."273

\section{H. Alberta Wetland Policy}

1. REPORT OF THE ALBERTA ENVIRONMENTAL

APPEAL BOARD ON WETLANDS AFFECTED BY THE

SOUTHWEST CALGARY Ring RoAD PROJECT

On 24 November 2017, the Alberta Environmental Appeals Board (the Board) released its Report and Recommendations (the Report) in the appeal from Alberta Environment and Parks' (the AEP) decision to issue Approval Number 00388473-00-00 under the Water Act ${ }^{274}$

See British Columbia, Environment and Climate Change Strategy, Professional Reliance Review: The Final Report of the Review of Professional Reliance in Natural Resource Decision-Making, by Mark Haddock (18 May 2018), online: <https:/engage.gov.bc.ca/app/uploads/sites/272/2018/06/Profess ional_Reliance_Review_Final_Report.pdf $>$. British Columbia, Auditor General, An Audit of Compliance and Enforcement of the Mining Sector (May 2016), online: $<$ https://www.bcauditor.com/sites/default/files/publications/reports/OAGBC\%20Mining $\% 20$ Report $\% 20$ FINAL.pdf $>$.

273

Nelson Bennett, "Professional Reliance Model Under Review," Business in Vancouver (3 October 2017), online: $<$ https://biv.com/article/2017/10/professional-reliance-model-under-review $>$. RSA $200, \mathrm{c} \mathrm{W}-3$. 
to KGL Constructors (A Partnership) (KGL) (the Approval). ${ }^{275}$ The work allowed under the Approval involved construction of the Southwest Calgary Ring Road Project (the SWCRR).

While Alberta Transportation is the proponent for the SWCRR, KGL is the contractor hired to complete the construction work, and as such was the applicant for the Approval. On 11 August 2017, AEP issued the Approval for KGL to permanently disturb 24 wetlands through in-filling (11 partially infilled and 13 entirely infilled), for a total of 22.07 hectares of wetland loss, as well as to change the location of water for the purpose of dewatering wetlands. The appeal was initiated by two private citizens, Mr. Brookman and Ms. Tulick. ${ }^{276}$

\section{a. Standard of Review}

Ultimately, the Board determined that the decision of the AEP should be reviewed on the correctness standard, with no deference to the decision-maker. It reached this conclusion after highlighting that the standard of review to be applied by a tribunal in reviewing an initial decision-maker's decision differs from that to be applied by the courts in their capacity to conduct judicial review. The Board further considered it relevant that the result of the appeal would be a report to the Minister recommending either that the AEP's decision should be maintained or the Minister's decision should substitute it. ${ }^{277}$

\section{b. Appropriateness of the Approval}

The Report recommended that the Approval remain intact, but with some variations and extensions to monitoring conditions already contained in the Approval, and to require KGL to complete an assessment of the wetlands impacted by the SWCRR using criteria outlined in the 2013 Alberta Wetland Policy (the 2013 Policy).

Overall the Board determined that there was "little latitude for altering the design of the [SWCRR] and limited ability to avoid some of the wetlands" ${ }^{278}$ and found indications that KGL had made at least some attempts to minimize the impacts of the SWCRR project where possible. $^{279}$

\section{c. Appropriate Wetland Policies to Apply}

Included in the appeal were arguments addressing whether the 1993 Interim Wetland Policy (the Interim Policy) or the 2013 Wetland Policy should be applied in the circumstances. The most relevant difference between the Interim Policy and the 2013 Policy in the circumstances was the difference in compensation calculation contained in each. ${ }^{280}$ The Interim Policy included a strict 3:1 hectare ratio to be employed. The 2013 Policy included

\footnotetext{
275 Brookman and Tulick v Director, South Saskatchewan Region, Alberta Environment and Parks, 2017 AEAB 13 [Brookman Report].

Ibid at paras $1-2$.

Ibid at para 202.

Ibid at para 335 .

Ibid.

Ibid at paras 369,412 .
} 
a case-by-case calculation of compensation, which applies a range of ratios from 8:1 to 1:1 based on the relevant wetland value. ${ }^{281}$

In determining which policy was appropriate to apply, the Board considered when stages of the work were completed, when the application was filed, what the application actually applied for, and the prerequisites included in the relevant directive. ${ }^{282}$

In particular, the Board, and the Minister agreed, that it was determinative of the issue that the work processed under the Interim Policy was not completed until $2016 .{ }^{283}$ The Minister clarified that "all field work must have been completed before the end of the 2015 growing season" for the Interim Policy to apply. ${ }^{284}$ While the application for the subject field work was processed under the Interim Policy, the field work was not completed until 2016, bringing it under the 2013 Policy.

The Board further noted that both the Interim Policy and the 2013 Policy take a hierarchical approach to approvals involving damage to wetlands, both emphasizing avoidance of harm to a wetland as the preferred course of action, then minimization, then compensation. $^{285}$

Ultimately, the Board determined that the 2013 Policy should have been applied by the AEP, and recommended that the Approval be amended to require the proponent to re-classify wetlands and assess each of the 24 affected wetlands using the criteria in the 2013 Policy. ${ }^{286}$ The Board noted that the average compensation under the 2013 Policy is 2.5 to 2.6 hectares which is lower than the Interim Policy would require. ${ }^{287}$

\section{d. The Minister's Order and Reasons}

Minister Phillips issued Ministerial Order 06/2018 on 29 January 2018 (the Order), which varied the Board's decision and notably provided 9 pages of reasons (an uncommon occurrence in such circumstances). The Order added a number of monitoring and reporting conditions, and agreed with the Board that the 24 wetlands be assessed under the 2013 Policy. Additionally, the Order went further than the Report and required that one of the wetlands (Wetland 06 known as Beaver Pond) be entirely undisturbed, ${ }^{288}$ and that "all possible options for avoidance and mitigation of Wetlands 07 and 08 be considered."289

The Order and the Minister's reasons go on to highlight that a strict application of the hierarchy included in the 2013 Policy needs to be followed in future decisions by the AEP. Specifically, Minister Phillips stated that compensation is the last alternative in the hierarchy

\footnotetext{
$281 \quad$ Ibid at para 370

$282 \quad$ Ibid at para 405.

283 Ibid at paras 411, 414; Ministerial Order 06/2018, "Order Respecting Environmental Appeals Board Appeal Nos. 17-047 and 17-050” (29 January 2018) [29 January 2018 Ministerial Order]. Available online: <www.eab.gov.ab.ca/dec/17-047-050-R.pdf> following the AEP decision.

28429 January 2018 Ministerial Order, ibid at para 21 [emphasis in original].

285 Brookman Report, supra note 275 at para 412.

$286 \quad$ Ibid at para 414.

$287 \quad$ Ibid at para 415.

288 29 January 2018 Ministerial Order, supra note 283

$289 \quad$ Ibid at para 18.
} 
"even where the project involves significant provincial infrastructure," 290 and emphasizes that the focus should be on avoidance first and foremost.

\section{Aboriginal Law and the Duty to Consult}

\section{A. Aboriginal Consultation Developments}

The Alberta Aboriginal Consultation Office (ACO) has recently expressed its intention to renew consultation policies and guidelines for both First Nation and Métis populations. ${ }^{291}$ Other case law developments of interest, particularly as related to procedural fairness, are noted below.

\section{ATHABASCA CHIPEWYAN FIRST NATION V. ALBERTA 292}

In Athabasca Chipewyan First Nation, the Athabasca Chipewyan First Nation (ACFN) sought judicial review of a decision of the ACO that a duty to consult the ACFN in respect of the Grand Rapids pipeline project was not triggered. The ACFN did not suggest the matter should be returned to the ACO for reconsideration. Furthermore, the decision of the AER approving the project was not challenged. Instead, the ACFN sought declarations that:

- the ACO had no authority to make the decision whether the duty to consult was triggered;

- the ACO's decision that there was no duty to consult was incorrect; and

- the manner in which the ACO made its decision that there was no duty to consult was procedurally unfair and in violation of the honour of the Crown. ${ }^{293}$

The ABQB did not grant the ACFN the declarations it sought, but instead provided an analysis of certain elements related to the issues that may be helpful to future cases.

a. Authority of the ACO to Make

Determinations on the Duty to Consult

The Alberta Court of Queen's Bench decided to opine on the first issue since the ACO's authority had not previously been challenged and a court ruling on the matter would be of practical utility to future cases. ${ }^{294}$ On this issue the Court found that the ACO does have the authority to determine whether there is a duty to consult, since governments may set up administrative schemes or policies to discharge this duty. ${ }^{295}$ Furthermore, the Court

\footnotetext{
$290 \quad$ Ibid at para 12.

291 Alberta, Indigenous Relations, "Indigenous Consultation Policies and Guidelines Renewals" (2018), online: $<$ www.indigenous.alberta.ca/fncp.cfm $>$.

2018 ABQB 262 [Athabasca Chipewyan First Nation].

Ibid at para 4.

Ibid at para 59

Ibid at paras 63,65 .
} 
concluded that no statutory authority is required for the ACO to have this power since it is an office established by the Crown and given authority by the same. ${ }^{296}$

\section{b. Duty to Consult Not Triggered Solely by Taking Up Land}

The Alberta Court of Queen's Bench disagreed with the position of the ACFN that the taking up of land in the treaty area was alone sufficient to trigger the Crown's duty. ${ }^{297}$ On this matter the Court reiterated that whether the duty to consult is triggered depends on the legal tests outlined in case law and in order for a duty to consult to be triggered, the taking up must have the potential to adversely impact a First Nation's exercise of Treaty Rights in a particular area. ${ }^{298}$

In determining the First Nations to whom the Crown owed a duty to consult, the ACO used a GeoData Mapping tool, which indicated certain areas where certain indigenous groups may have interests and to aid in decisions during the consultation process. ${ }^{299}$

The Court agreed with the ACFN that a consultation map would not be necessarily sufficient to determine whether a duty to consult is triggered and that the ACO may not exclusively rely on the mapping. The mapping project rather is an ongoing policy initiative and should not be the only tool used by the government when considering whether a duty to consult arises. $^{300}$

\section{c. Duty of Procedural Fairness Engaged for}

ACO Decisions on Duty to Consult

The Court in this instance declined to consider whether a duty of procedural fairness was breached since a declaration regarding the manner in which the Crown came to its decision would have no effect on the project, given the relief sought by the ACFN. ${ }^{301}$ However, in its comments on the broader question of whether a duty of procedural fairness exists, the Court found that since the ACO is an agent of the Crown making an administrative decision on aboriginal treaty rights, the decision of whether a duty to consult is triggered does engage a duty of procedural fairness. ${ }^{302}$

In the context of the ACO's decisions, the Court determined that the duty of procedural fairness requires communication between the ACO and the First Nation where a decision on triggering the duty to consult is contested. ${ }^{303}$ If the First Nation believes there was a duty to consult, and the ACO does not agree, the ACO must provide notice to the First Nation that a final determination will be made on the issue and must outline what procedure it will undertake in making its determination. ${ }^{304}$ This would include informing the First Nation of

Ibid at para 66.

Ibid at para 71

Ibid at paras $72,91$.

Ibid at para 26.

Ibid at para 88 .

Ibid at para 101.

Ibid at paras 105-106, 109.

Ibid at para 113 .

Ibid at para 15 . 
the evidence required to meet the trigger test and any procedural deadlines. ${ }^{305}$ The Court also found that a duty of procedural fairness requires the ACO to provide reasons for its decision in order to demonstrate that it fully and fairly considered the information and evidence submitted. ${ }^{306}$

\section{TASEKo MinEs LIMITED V. CANADA (ENVIRONMENT)}

Taseko Mines Limited (Taseko) brought two applications for judicial review following a determination under the CEAA, 2012 ${ }^{307}$ that the New Prosperity Gold-Copper Mine (New Prosperity) was likely to cause significant adverse environmental effects. A review panel released its report in October 2013 and made findings of anticipated significant adverse environmental effects (the Report). In February 2014, the Minister of Environment (Minister) decided that the New Prosperity was likely to cause significant adverse environmental effects, and the Governor in Council (GIC) decided that the effects were not justified in the circumstances. The first judicial review sought review of the Report. The second judicial review sought to quash the decision of the Minister and GIC. On 5 December 2017, the Federal Court released two decisions, both styled as Taseko Mines Limited v. Canada (Environment), ${ }^{308}$ dismissing the judicial review applications of the Report and the decisions of the Minister and GIC, respectively.

\section{a. Background}

In Taseko 2, the Federal Court considered the procedural fairness owed by the Minister and GIC to the proponent in reaching their decisions under CEAA, 2012 following the release of the Report, as well as the interaction between the duty of fairness to a proponent and the duty of consultation to First Nations.

New Prosperity was a proposed open pit gold and copper mine within the traditional territory of the Tsilhqot'in peoples. After the close of the hearing before the review panel, both Taseko and the Tsilhqot'in National Government (TNG) had contact with the federal government. On 31 October 2013, the Report was released, which marked the commencement of consultation between the Crown and the TNG regarding the Report. Both Taseko and the TNG had contact with, and submitted material to, the federal government during the Minister's and GIC's decision-making processes.

\section{b. Procedural Fairness Owed by the Minister and GIC}

Taseko's central complaint was that it should have been informed of any submissions received by the Minister in opposition to New Prosperity, and that it should have been afforded an opportunity to respond prior to the final decision. ${ }^{309}$

\footnotetext{
$305 \quad$ Ibid at para 116.

$306 \quad$ Ibid at para 117

$307 \quad$ Supra note 183.

3082017 FC 1099 [Taseko 1]; 2017 FC 1100 [Taseko 2].

Taseko 2, ibid at para 66 .
} 
With respect to the whether Taseko was afforded procedural fairness during the Minister's decision-making processes, the Court held that unlike the joint review panel process, where the proponent is entitled to a high degree of procedural fairness, Taseko was entitled only to a minimal degree of procedural fairness during the Minister's decision-making process, which did not include the right to be informed of any and all communications between TNG and the Minister. ${ }^{310}$ The Court held that Taseko was not owed procedural fairness during the GIC's decision-making process. ${ }^{311}$

\section{c. Procedural Fairness and the Duty to Consult}

With respect to the intersection of procedural fairness and the Crown duty of consultation, the Court affirmed that post-hearing consultation between the Minister and the TNG on the Report was required and appropriate. The Court held that the Crown duty of consultation and the duty of fairness to the proponent can exist in harmony. ${ }^{312}$ The Court therefore appeared to acknowledge that some duty of fairness could be owed to the proponent in the context of Crown consultation. The Court recognized that new information, which the Crown intends to rely on and that materially affects the proponent, ought to be provided to the proponent. However, the Court also held that the proponent does not have a "right" to take part in consultations between the Crown and a First Nation, ${ }^{313}$ and further recognized that that in pursuit of the goal of reconciliation, Crown consultation might be adversely impacted by a requirement that every interaction between the Crown and First Nation be provided to the proponent. $^{314}$

Overall, in Taseko 2, the Court found that Taseko was afforded a fair process in terms of the Minister's decision-making, having regard to the nature of the communications, the absence of new information or evidence raised by TNG, and the Crown's obligation to consult with TNG. While the Court's findings in Taseko 2 permitted the Crown to rely on TNG's submissions without providing them to Taseko for an opportunity to respond, the decision does recognize that if new information is raised, that the Crown intends to rely on, the proponent ought to be informed.

\section{B. EXTRACTIVE SECTOR TRANSPARENCY MEASURES ACT IN EFFECT FOR PAYMENTS TO INDIGENOUS GovernMENTS}

\section{BACKGROUND}

A further consideration for proponents in consultation are the recent developments under the Extractive Sector Transparency Measures Act, ${ }^{315}$ which has been in force since 1 June 2015. Under ESTMA, entities that are listed on a Canadian exchange or meet certain size requirements and are engaged in the commercial development of oil, gas, and minerals are 
required to file an annual report disclosing certain cash and in-kind payments made by them to domestic and foreign governments.

\section{TRANSITIONAL PERIOD FOR PAYMENTS TO INDIGENOUS GOVERNMENTS}

When the ESTMA first entered into force it included transitional provisions for Indigenous governments in Canada (the Transitional Provisions). ${ }^{316}$ The Transitional Provisions in section 29 of ESTMA outlined a two-year period during which provisions of the Act would not apply to any payment made by an entity to

(a) an Aboriginal government in Canada;

(b) a body established by two or more Aboriginal governments in Canada; and

(c) any trust, board, commission, corporation or body or authority that is established to exercise or perform, or that exercises or performs, a power, duty or function of government for a government referred to in paragraph (a) or a body referred to in paragraph (b). ${ }^{317}$

The enactment of this transitional period was in response to comments from industry and indigenous stakeholders who indicated it was necessary to determine potential implications associated with reporting payments made to Indigenous governments. ${ }^{318}$

\section{IMPLEMENTATION FOR PAYMENTS TO INDIGENOUS GOVERNMENTS}

On 1 June 2017, the end of the transitional period of non-application of ESTMA to Aboriginal governments was marked. As a result, payments to Indigenous governments are now captured by the same transparency obligations that apply to payments made to domestic and foreign governments. The onus to report the payment is on the extractive company, not on the Indigenous government.

Although extractive companies are not required to disclose Impact and Benefit Agreements (IBA) under the Act, certain payments included within IBAs may be required to be disclosed now that the transitional period has lapsed. This includes certain types of payments made in relation to commercial development of oil, gas, and minerals of $\$ 100,000$ or more. ${ }^{319}$ In April 2018, the federal government released a revised version of its guidance document, validation checklist, reporting template, and a new information sheet on reporting payments to Indigenous payees, which includes illustrative examples. ${ }^{320}$ Failure to comply with the reporting requirements or an order by the Minister made under ESTMA may lead to an offence punishable on summary conviction and liable to a fine of up to $\$ 250,000$. $^{321}$ at 2, online: $<$ https://www.nrcan.gc.ca/sites/www.nrcan.gc.ca/files/mining-materials/PDF/ESTMA\%20 Info $\% 20$ Sheet $\% 20-\% 20$ Indigenous $\% 20$ Govts.pdf $>$.

319 ESTMA, supra note 176, s 2, "payment."

320 These tools are available online: <https://www.nrcan.gc.ca/mining-materials/estma/18192>.

321 ESTMA, supra note 176, s 24(1). 


\section{BILL C-262 AND THE IMPLEMENTATION OF UNDRIP}

On 21 April 2016, Romeo Saganash, NDP Member of Parliament (MP) for Abitibi-BaieJames-Nunavik-Eeyou introduced Bill C-262, An Act to ensure that the laws of Canada are in harmony with the United Nations Declaration on the Rights of Indigenous Peoples. ${ }^{322}$ As its name indicates, the purpose of Bill C-262 is to bring Canadian law in line with the United Nations Declaration on the Rights of Indigenous Peoples (UNDRIP). The Canadian government officially adopted the UNDRIP without any qualifications in May 2016, but had initially hesitated to enact the UNDRIP's contents into domestic Canadian law. ${ }^{323}$

The future of Bill C-262 became more certain after the Liberal government confirmed that it intended to support the private member's Bill in November $2017 .{ }^{324}$ Following its Second Reading, the Parliamentary Secretary to the Minister of Indigenous and Northern Affairs noted that UNDRIP and Bill C-262 are "a priority for our government and that we fully intend to honour these priorities." ${ }^{325}$ Bill C-262 passed Second Reading on 7 February 2018, and after review by the Standing Committee on Indigenous and Northern Affairs in March 2018, it was returned to Parliament on 9 May 2018 without amendment. ${ }^{326}$

Bill C-262 would require federal action in three areas. First, it would cause the UNDRIP to be affirmed as a universal international human rights instrument with application in Canadian law. ${ }^{327}$ Second, it would require the government of Canada to "take all measures necessary to ensure that the laws of Canada are consistent with the United Nations Declaration on the Rights of Indigenous Peoples." ${ }^{328}$ Third, it would require the federal government to develop and implement a national action plan in consultation and cooperation with Indigenous peoples to achieve the objectives of the UNDRIP. ${ }^{329}$

In order to document the government's progress at achieving the requirements of Bill C262, the Minister of Indian Affairs and Northern Development is required to submit a yearly report on the implementation of the measures contained in UNDRIP and the national action plan. $^{330}$

Bill C-262 itself contains the full text of the UNDRIP as adopted by the United Nations on 13 September 2007 in the Schedule to the text. A few articles of the UNDRIP may be notable to the energy industry as they introduce a requirement for free, prior and informed

1st Sess, 42nd Parl, 2015-16-17-18 (as passed by the House of Commons 30 May 2018) [Bill C-262]. Indigenous and Northern Affairs Canada, "United Nations Declaration on the Rights of Indigenous Peoples" (3 August 2017), online: <https://www.aadnc-aandc.gc.ca/eng/1309374407406/13093744 $58958>$; Tim Fontaine, "Canada Officially Adopts UN Declaration on Rights of Indigenous Peoples," CBC News (10 May 2016), online: <www.cbc.ca/1.3575272>.

John Paul Tasker, "Liberal Government Backs Bill that Demands Full Implementation of UN Indigenous Rights Declaration," CBC News (21 November 2017), online: <www.cbc.ca/1.4412037>. House of Commons Debates, 42nd Parl, 1st Sess, No 245 (5 December 2017) at 16076.

House of Commons, Standing Committee on Indigenous and Northern Affairs, Thirteenth Report: Bill C-262, An Act to ensure that the laws of Canada are in harmony with the United Nations Declaration on the Rights of Indigenous Peoples (8 May 2018) (Chair: Hon. MaryAnn Mihychuk).

Bill C-262, supra note 322, cl 3.

Ibid, cl 4.

Ibid, cl 5.

Ibid, $\mathrm{cl} 6$. 
consent by Indigenous peoples before the government or others can engage in certain activities. In particular:

- $\quad$ Article 32 requires that states

\begin{abstract}
consult and cooperate in good faith with the indigenous peoples concerned through their own representative institutions in order to obtain their free and informed consent prior to the approval of any project affecting their lands or territories and other resources, particularly in connection with the development, utilization or exploitation of mineral, water or other resources.... States shall provide effective mechanisms for just and fair redress for any such activities, and appropriate measures shall be taken to mitigate adverse environmental, economic, social, cultural or spiritual impact. ${ }^{331}$
\end{abstract}

- Article 29 holds that "Indigenous peoples have the right to the conservation and protection of the environment and the productive capacity of their lands or territories and resources." ${ }^{332}$

- Article 19 requires that states "consult and cooperate in good faith with the indigenous peoples concerned through their own representative institutions in order to obtain their free, prior and informed consent before adopting and implementing legislative or administrative measures that may affect them." 333

As currently written, Bill C-262 has the potential to lead to impacts on the energy industry, other federal legislation, and on the body of common jurisprudence that has been developed on the subject of the duty to consult.

\title{
VI. BANKRUPTCY AND ABANDONMENT LIABILITY
}

\section{A. BANKRUPTCY AND INSOLVENCY - THE "REDWATER" DECISIONS}

On 15 February 2018, the Supreme Court of Canada heard the appeal of the Alberta Court of Appeal's decision in Orphan Well Association v. Grant Thornton Limited. ${ }^{334}$ As of writing, the Supreme Court has not yet handed down its judgment, but the series of decisions leading to the Supreme Court of Canada hearing is often referred to as "Redwater."

At issue in the appeal was whether or not a Trustee or Receiver under the Bankruptcy and Insolvency $A c t,{ }^{335}$ can rely on section 14.06 to disclaim oil and gas infrastructure, including wells and pipelines, where the abandonment and reclamation obligations of each individual

\footnotetext{
$331 \quad$ Ibid, Schedule, art 32.

Ibid, Schedule, art 29.

Ibid, Schedule, art 19.

2017 ABCA 124 [Orphan Wells].

RSC 1985, c B-3.
} 
asset exceeded the realizable monetary value in a liquidation of those assets. In the words of Justice Slatter of the Alberta Court of Appeal:

\begin{abstract}
Shortly put, Redwater Energy Corporation is an insolvent oil and gas company. It owns some oil wells that are valuable, and others that may potentially be declared "orphans" because the costs of environmental remediation required to abandon them exceed the value of those wells... Redwater's trustee in bankruptcy wants to renounce or disclaim Redwater's interest in the orphan wells, but keep and sell the valuable wells to maximize the recovery of the secured creditor. The Alberta Energy Regulator says that this is not permissible, and a sufficient portion of the sale proceeds from the valuable wells must be set aside to meet the expected costs of remediating the orphan wells. ${ }^{336}$
\end{abstract}

The Supreme Court of Canada's decision will have significant impact on the Alberta oil and gas industry, where there are currently an estimated 60,000 individual wells which have been suspended but not yet fully abandoned and reclaimed. More broadly though, the case has received widespread attention in Alberta and across Canada due to its potential impact on the provincial regulator's ability to regulate natural resource companies put into receivership or bankruptcy.

\title{
B. Alberta Energy Regulator Directive 67
}

On 6 December 2017, the AER released a new edition of "Directive 067: Eligibility Requirements for Acquiring and Holding Energy Licenses and Approvals." ${ }^{\text {"37 }}$ Its release occurred on the heels of the AER's suspension of Lexin Resources Ltd.'s licenses, forcing it into receivership, leaving the Orphan Well Association with nearly 1,100 wells. In its bulletin announcing the update, the AER made its reasons for the update clear: "[a]cquiring and holding a license or approval in Alberta is a privilege, not a right. This new edition of the directive increases the scrutiny the AER applies to ensure that this privilege is only granted to, and retained by, responsible parties."338

Directive 67 sets out the rules by which a person may hold an AER license. In this new edition, the AER has expanded its powers to collect information and adopted broad discretion to assess whether a licensee poses an "unreasonable risk." 339 The AER's discretion is accompanied by the power to impose terms and conditions on a license holder wherever it determines it necessary to address that risk. Under the new edition, these terms and conditions may include the number and types of licenses that a licensee may hold, security requirements, requirements on the minimum or maximum working interest percentages permitted, and requirements to address non-compliances of current or former AER licensees that are directly or indirectly associated with the licensee.

Orphan Wells, supra note 334 at para 2 [citations omitted].

Alberta Energy Regulator, "Directive 067: Eligibility Requirements for Acquiring and Holding Energy Licences and Approvals" (6 December 2017), online: <https://www.aer.ca/documents/directives/ Directive067.pdf ["Directive 67"]. 338 Alberta Energy Regulator, "Bulletin 2017-21: New Edition of Directive 067: Eligibility Requirements
for Acquiring and Holding Energy Licences and Approvals" (6 December 2017), online: < https://www. aer.ca/regulating-development/rules-and-directives/bulletins/bulletin-2017-21>.

339 
Under the earlier edition of Directive 67, the AER collected only basic information from new licensees and had limited provisions mandating it be updated. The new edition includes an updated disclosure document (Schedule 1) that requires substantially more information on the licensee, including the company's compliance history, corporate structure, and financial health. ${ }^{340}$ The Directive also expands its reach to the directors, officers, and certain shareholders (that is, those owning more than 20 percent of the outstanding voting securities) and their current or historical involvement with companies subject to outstanding compliance orders or with bankrupt or insolvent companies in Alberta or elsewhere. Directors must swear to the contents of the disclosure document and must have a third party attest to their identity.

Following the introduction of the new edition of Directive 67, existing licensees were required to submit the updated Schedule 1 for 31 January 2018. ${ }^{341}$ Moving forward, licensees must now provide the AER with an updated Schedule 1 within 30 days of any "material change," which includes

- changes to legal status and corporate structure;

- addition or removal of a related corporate entity;

- amalgamation, merger, or acquisition;

- changes to directors, officers, or control persons;

- [any of a list of indicators of insolvency, receivership, or bankruptcy];

- or cancellation of insurance coverage. $^{342}$

The AER notes that any of the above may lead to a change in the AER's assessment of the licensee's risk profile. Licensees may apply to the AER for an advance ruling on whether the AER would consider the change an unreasonable risk, which the AER has stated it will process within 10 business days. ${ }^{343}$

Additionally, pursuant to Bulletin 2017-13 (the Bulletin), ${ }^{344}$ the AER introduced a new requirement whereby all applications to transfer AER approvals from one approval holder to another must be bundled for review. Under the Bulletin, which took effect 21 August 2017, bundled license transfer applications are then subject to a standardized review period, where they are posted on the AER website for comment, for at least 30 days before a

Ibid at Schedule 1; Alberta Energy Regulator, "Frequently Asked Questions: Directive 067: Eligibility Requirements for Acquiring and Holding Energy Licences and Approvals" (January 2018), online: $<$ https://www.aer.ca/documents/directives/Directive067_FAQ.pdf> ["Directive 67 FAQ"]. The AER describes corporate structure as including

(1) direct parent entities of the applicant or eligible licensee, (2) subsidiaries of the applicant or eligible licensee, (3) any persons or companies that hold more than 20 per cent of the outstanding voting securities of the applicant or eligible licensee, and (4) entities that share the majority of their directors, officers, or other control persons with the applicant or eligible licensee. Only the immediate parent entities need to be listed; you do not need to list any entities that own the parent entity" (ibid at 1).

The AER has indicated that financial health will be determined on the basis of a company's audited financial statements.

"Directive 67 FAQ," ibid at 3 .

"Directive 67," supra note 337 at 6 [footnotes omitted].

"Directive 67 FAQ," supra note 340 at 3.

Alberta Energy Regulator, "Bulletin 2017-13: Changes to Process for Transfer Application Decisions" (24 July 2017), online: <https://www.aer.ca/regulating-development/rules-and-directives/bulletins/ bulletin-2017-13>. 
decision to approve the associated license transfer applications is issued. The AER stated that the "overall result is a consistent and transparent decision-making process that allows for stakeholder input on related applications.",345

The purpose of the public notice is to allow interested parties (such as landowners, First Nations groups, and other energy companies) to file a Statement of Concern during the review period. Presumably, this 30-day public review period would occur after the AER's review process created by Directive 67, and would mainly impact parties completing land and facility transactions where multiple licenses are transferred between the same two parties at once.

\section{INTRODUCTION OF THE BRITISH COLUMBIA ORPHAN SITE RECLAMATION FUND LEVY}

On 25 April 2018, the British Columbia government approved Bill 15-2018, Energy, Mines and Petroleum Resources Statutes Amendment Act, $2018^{346}$ that aims to strengthen the province's orphan well restoration and prevention regime.

Bill 15 will replace the current orphaned site restoration tax under the Oil and Gas Activities $A c t^{347}$ with a levy to be paid by permit holders to the British Columbia Orphan Site Reclamation Fund (OSRF) to pay the costs of restoration and environmental clean-up. Bill 15 gives the Oil and Gas Commission (OGC) the power to determine the total amount that is to be raised by the levy and is permitted to impose the levy more than once a year in order to ensure that the OSRF remains adequately funded. ${ }^{348}$

Bill 15 also intends to limit orphan sites by granting the OGC the power to require permit holders to conduct restoration work on inactive sites. ${ }^{349}$ It may also refuse permit requests if the applicant or permit holder (either itself or through its "associates," including officers, directors, agents, shareholders, or any person the OGC believes has an influence over the applicant or permit holder) had a history of non-compliance or questionable conduct. ${ }^{350}$

\section{Power Markets and Renewable Programs}

\section{A. Power Purchase Agreements AND THE Balancing PoOL}

Litigation in Alberta over the power Purchase Arrangements (PPAs) continued in 2017. As noted in prior updates in $2015^{351}$ and $2016,{ }^{352}$ several power purchasers announced their decision to terminate their PPAs on the basis that increased compliance costs under the

\footnotetext{
$345 \quad$ Ibid.

346 3rd Sess, 41st Parl, British Columbia, 2018 [Bill 15].

SBC 2008, c 36.

Bill 15, supra note 346, cl 12, s 47 of the Oil and Gas Activities Act as it will be amended.

Ibid, cl 24, s 111.1 of the Oil and Gas Activities Act as it will be amended.

Ibid, cl 3, s 26 of the Oil and Gas Activities Act as it will be amended.

Terri-Lee Oleniuk, Jeremy Barretto \& Joel Forrest, "Recent Regulatory and Legislative Developments of Interest to Energy Lawyers" (2015) 53:2 Alta L Rev 529.

352 Evan W Dixon, Hazel A Saffery \& C James Cummings, "Recent Regulatory and Legislative
} Developments of Interest to Energy Lawyers” (2016) 54:2 Alta L Rev 511. 
Specified Gas Emitters Regulation, ${ }^{353}$ as part of the overarching Climate Leadership Act, ${ }^{354}$ made the PPAs unprofitable or more unprofitable, giving the buyers the right to terminate under change in law provisions. In July 2016, the Government of Alberta commenced a legal action against the Balancing Pool, the Alberta Utilities Commission, and individual PPA holders seeking declarations regarding the validity of certain provisions of the PPAs, including a declaration that the specific clause allowing the PPA holders to terminate based on a change in law was void and unlawful. ${ }^{355}$ As discussed below, following several developments in 2017 and 2018, the litigation is now resolved.

With respect to the Government-initiated litigation regarding the validity of the terminations, the Government of Alberta had reached settlement will all Buyer Respondents except ENMAX by the end of $2016^{356}$ and finally settled with ENMAX in March 2018. ${ }^{357}$ With this agreement, "the legal action between the Government of Alberta, ENMAX and the remaining parties" was ended. ${ }^{358}$ The terms and conditions of settlement required the terminating parties to provide cash payments and emission credits to the Balancing Pool. ${ }^{359}$ The Government of Alberta has stated the "carbon offset contribution allows the Balancing Pool greater flexibility in meeting its future greenhouse gas emissions compliance obligations for the PPAs it will hold." 360

The Balancing Pool was the subject of two challenges by ENMAX. First, in ENMAX PPA Management Inc. v. Balancing Pool, ${ }^{361}$ issued on 11 October 2017, ENMAX asked the Court of Queen's Bench to determine whether its termination of the Battle River PPA was effective on the termination date identified by ENMAX in its termination notice to the Balancing Pool; or on the date when the Balancing Pool completed its assessment, concluded that the termination was valid, and took dispatch and offer control. Based on the statutory and regulatory framework, as well as the specific terms and conditions of the Battle River PPA, the Court ruled in favour of ENMAX and determined that the effective date of termination was the date specified in the notice of termination.

Alta Reg 139/2007.

SA 2016, c C-16.9.

See Alberta (Attorney General) v Alberta Power (2000) Ltd, 2017 ABQB 195; Alberta (Attorney General) v Alberta Power (2000) Ltd, 2018 ABQB 100.

Government of Alberta, News Release, "Additional PPA Agreements Reached" (16 December 2016), online: $<$ https://www.alberta.ca/release.cfm?xID=45030634367A5-A379-EDF7-2EF256AC97F90C02> [16 December News Release].

Government of Alberta, News Release, "Alberta and ENMAX Reach Agreement" (9 March 2018), online: $<$ https://www.alberta.ca/release.cfm?xID=5355478564911-A514-1434-7898391070A24A5B . Ibid.

For example, the settlement agreement with ENMAX provided for the transfer to the Balancing Pool of 166,667 carbon offset credits and for a payment of equivalent value to ENMAX from the Balancing Pool for previously disputed and unpaid dispatch services and PPA transition matters (Balancing Pool, News Release, "GOA and ENMAX Agree to Withdraw ENMAX from the PPA Legal Action" (12 March 2018), online: <www.balancingpool.ca/wp-content/uploads/2017/12/News-Release_2018ENMAX-Settlement.pdf $>$ ). In the case of AltaGas Ltd, and the PPAs for Sundance B, the settlement provided for AltaGas to transfer 391,879 self-generated carbon offsets and pay \$6 million to the Balancing Pool over three years starting in 2018. In connection with the PPAs for Sundance A and B and Sheerness, TransCanada also provided value with a package of carbon offset credits (Government of Alberta, News Release, "Additional PPA Agreements Reached" (16 December 2016), online: $<$ https://www.alberta.ca/release.cfm?xID=45030634367A5-A379-EDF7-2EF256AC97F90C02>). 16 December News Release, supra note 356. 2017 ABQB 605. 
In ENMAX Energy Corporation v. Balancing Pool, ${ }^{362}$ issued on 22 November 2017, the Court of Queen's Bench also considered an application by ENMAX regarding the Balancing Pool's refusal to complete its assessment of ENMAX's notice of termination for the Keephills PPA. The Court ruled in ENMAX's favour and granted an injunction compelling the Balancing Pool to: (a) forthwith and in good faith complete its assessment of ENMAX's termination of the Keephills PPA, and (b) communicate the result of such assessment and verification of the termination notice provided by ENMAX without delay. The Court dismissed ENMAX's request for interim injunction to compel the Balancing Pool to assume offer and dispatch control with respect to the Keephills PPA on the basis that it was premature. In December 2017, the Balancing Pool completed its assessment as required under the legislation and verified the occurrence of an extraordinary event, confirming ENMAX's right to terminate the Keephills PPA. ${ }^{363}$

After legislatively mandated consultations with the Department of Energy and representatives of electricity consumers regarding the reasonableness of such action, ${ }^{364}$ the Balancing Pool proceeded to terminate the PPAs for Sundance B and C (September 2017) ) $^{365}$ and Battle River (March 2018). ${ }^{366}$ The PPA for Sundance A expired on 31 December 2017. Pursuant to section 97(c) of the Electric Utilities Act, the Balancing Pool may terminate a PPA held by it, if among other things, it "pays the owner or ensures that the owner receives an amount equal to the remaining closing net book value of the generating unit." ${ }^{367}$ The Balancing Pool has stated that it will continue to evaluate the relative merits of terminating, holding, or selling further PPAs as circumstances and market conditions evolve. ${ }^{368}$

\section{B. Renewable Energy Programs in Alberta AND SASKATCHEWAN}

\section{Alberta's Renewable Electricity Program - ROUNDS 1, 2, AND 3}

According to the National Energy Board's 2017 Renewable Power Report, Alberta's 2016 generation capacity mix included coal (37.9 percent), natural gas (45.3 percent), wind (8.8 percent), hydro (5.4 percent), and biomass (2.6 percent) ${ }^{369}$ All renewable sources accounted for 16.8 percent of the total generation capacity in Alberta. ${ }^{370}$ Alberta generates the third

2017 ABQB 718.

Balancing Pool, News Release, "Balancing Pool Verifies Buyer Termination of Keephills Power Purchase Arrangement" (7 December 2017), online: <www.balancingpool.ca/wp-content/uploads/ 2017/12/News-Release-Keephills-PPA-Termination-Final.pdf>.

Electric Utilities Act, SA 2003, c E-5.1, s 97(a).

Balancing Pool, News Release, "Balancing Pool to Terminate Sundance B and Sundance C Power Purchase Arrangements" (18 September 2017), online: <www.balancingpool.ca/wp-content/uploads/ 2017/09/News-Release_2017-Sundance-Terminations.pdf $>$.

Balancing Pool, News Release, "Balancing Pool to Terminate Battle River 5 PPA" (21 March 2018), online:<www.balancingpool.ca/wp-content/uploads/2018/03/News-Release_2018-Battle-River-5-Term ination-1.pdf $>$.

Electric Utilities Act, supra note 364.

Balancing Pool, "Battle River 5 PPA Termination" (2018), online:<www.balancingpool.ca/battle-river5-ppa-termination/>.

Canada, National Energy Board, "Canada's Renewable Power Landscape: Energy Market Analysis 2017 " (2017) at 14, online: < https://www.neb-one.gc.ca/nrg/sttstc/lctrct/rprt/2017cndrnwblpwr/2017 cndrnwblpwr-eng.pdf $>$ [NEB Energy Market Analysis 2017]. Ibid. 
most wind power in Canada after Quebec and Ontario. ${ }^{371}$ However, Alberta's installed wind generation capability in 2017 remained unchanged from $2016 .{ }^{372}$ Alberta's first large-scale solar generation asset with the nominal capacity of 15 megawatts (MW) was energized by Brooks Solar in December 2017. ${ }^{373}$

As part of its Climate Leadership Plan adopted in late 2015, the Government of Alberta set the goal of eliminating coal-fired electricity generation and ensuring that 30 percent of Alberta's electricity is derived from renewable sources (such as wind, hydro, and solar) by $2030 .{ }^{374}$ To realize this major milestone and add 5,000 MW of renewable energy capacity by 2030, the Government of Alberta developed the Renewable Electricity Program (REP), which is implemented and administered by the Alberta Electric System Operator (AESO) through a series of competitive processes. As part of the REP, the successful project proponents will receive price-indexed support payments through Indexed Renewable Energy Credit (IREC) in exchange for renewable energy attributes from these projects. The Renewable Electricity Support Agreements between the AESO and individual project proponents will set out the terms and conditions governing the IREC.

As part of the request for proposal stage of the first round of the Renewable Electricity Program in the summer of 2017, the AESO received bid prices for 26 projects from 12 project proponents. ${ }^{375}$ To qualify for the first round of the REP, renewable energy projects were required to achieve commercial operation by December 2019 and utilize the existing transmission and distribution system. In December 2017, the AESO completed the first round of competition and announced three successful bids received from Capital Power (201 MW wind farm), EDP Renewables Canada Ltd. (248 MW wind farm), and Enel Green Power North America Inc. (115 MW and $31 \mathrm{MW}$ wind farms). ${ }^{376}$

The first round of Alberta's REP set a record for the lowest renewable electricity pricing in Canada with a weighted average price of $\$ 37 / \mathrm{MWh}^{377}$ As a result of the better-than expected bid prices, the AESO awarded $600 \mathrm{MW}$ of capacity, $200 \mathrm{MW}$ in excess of the Round 1 target of $400 \mathrm{MW} \cdot{ }^{378}$ According to the Government of Alberta, the first round of competition is expected to attract $\$ 1$ billion of investment from international and Albertabased companies, and create 700 construction and 40 long-term operational jobs in Alberta. ${ }^{379}$

Ibid at 13 .

Alberta Electric System Operator, “AESO 2017 Annual Market Statistics” (March 2018) at 22, online: $<$ https://www.aeso.ca/download/listedfiles/2017-Annual-Market-Stats.pdf $>$.

Alberta Electricity System Operator, "New Asset Brooks Solar(BSC1) Notice," online: AESO <https:// www.aeso.ca/market/market-updates/new-asset-brooks-solar-bsc1-notice/>.

Government of Alberta, "Renewable Electricity Program," online: $<$ https://www.alberta.ca/ renewableelectricity-program.aspx\#toc-4>.

Alberta Electric System Operator, "REP Round 1 Results," online: <https://www.aeso.ca/market/ renewable-electricity-program/rep-round-1-results/>.

Government of Alberta, News Release, "Alberta Renewables Auction Record-Setting Success" (13 December 2017), online: <https://www.alberta.ca/release.cfm?xID=511572D67D28E-C09C-E3E6BA37A772B4C34AF6>.

Ibid.

Ibid.

"Renewable Electricity Program," supra note 374. 
In February 2018, the AESO announced rounds two and three of the Renewable Electricity Program, which will continue to be fuel neutral (that is, no special treatment or carve outs for solar or biomass) and will be subject to the key terms and conditions set by the AESO for the first round of competition, including the standard form Renewable Electricity Support Agreements. Successful projects in rounds two and three will be required to achieve commercial operation no later than 30 June 2021 and the procurement targets are set at 300 MW (round two) and $400 \mathrm{MW}$ (round three) respectively. ${ }^{380}$ The competitive process will follow the same format as for the first round of the REP (Request for Expression of Interest, Request for Qualifications, and Request for Proposals, with the results to be announced by the end of 2018). The AESO has confirmed that rounds two and three will be exclusive of each other, with projects submitted for round two being prohibited from competing in round three. ${ }^{381}$ From an interconnection perspective, round three projects will be evaluated for their ability to connect to the grid after round two projects have been assessed.

REP Round 2 was, among other things, "developed to encourage the greatest participation by Indigenous communities." 382 As such, round two projects require a minimum of 25 percent Indigenous equity ownership which must be maintained for a minimum of three years following commercial operation of the facility. Eligible Indigenous communities must be located in Alberta and meet the Government's definition as one or a combination of the following: (a) First Nation communities, Métis settlements, Métis Nation of Alberta, and the Aseniwuche Winewak Nation; or (b) 100 percent Indigenous community-owned organization and/or business. The AESO launched the competition process for rounds two and three at the end of March 2018. ${ }^{383}$

To achieve the targets and objectives set out in its Climate Leadership Plan, the Government of Alberta also launched a range of other renewable energy programs and initiatives, including the Energy Efficiency Alberta, pilot Alberta Indigenous Solar and Community Energy Programs, On-Farm Solar Management, Solar for New Schools, Microgeneration, Seeking Solar Farm Proposal, etc. The Government of Alberta is expected to provide further financial support for renewable energy projects in 2018 and $2019 .{ }^{384}$

\section{AESO COMPREHENSIVE MARKET DESIGN PROPOSAL}

To support the Renewable Electricity Program and the phase-out of emissions from coalfired generation by 2030 under the 2015 Climate Leadership Plan, the AESO also recommended a transition from the current energy-only market to a new framework that would include an energy market and a capacity market. ${ }^{385}$ A capacity market allows for generators (and other qualifying participants) to be compensated for making capacity

Alberta Electric System Operator, "Renewable Electricity Program," online: $<$ https://www.aeso.ca/ market/renewable-electricity-program/>.

Ibid.

Alberta Electric System Operator, "REP Round 2," online: <https://www.aeso.ca/market/renewableelectricity-program/rep-round-2/>.

Supra note 380 .

"Renewable Electricity Program," supra note 374.

Alberta Electric System Operator, Alberta's Wholesale Electricity Market Transition Recommendation (3 October 2016) at 1, online: <https://www.aeso.ca/assets/Uploads/Albertas-Wholesale-ElectricityMarket-Transition.pdf $\$$. 
available to the market. Accordingly, qualifying generation is eligible for a payment in the capacity market and a payment in the energy market for generation that is dispatched.

In November 2016, the Government of Alberta supported this recommendation and directed the AESO to design and implement the capacity market by $2021 .^{386}$ The AESO engaged multiple working groups and stakeholders in the development of the capacity market design throughout 2017. As a result, the AESO produced three iterations of a Straw Alberta Market proposal containing working group design recommendations and consolidated them into a Comprehensive Market Design (CMD 1) proposal and accompanying rationale documents, which were released in January $2018 .{ }^{387}$ Following industry working groups, stakeholder feedback and expert advice, the AESO release its CMD 2 document in April 2018. The CMD documents are complex and technical, and are intended to establish the framework and rules by which the capacity market will operate. The CMD documents address various issues, such as who can participate in the market, capacity market auctions, rebalancing, performance of obligations, and payment mechanisms.

As discussed below in Part VII.C, the Alberta Government in April 2018 introduced Bill 13, An Act to Secure Alberta's Electricity Future ${ }^{388}$ one objective of which is to provide the necessary statutory support for the implementation of the capacity market and the CMD.

\section{SASKATCHEWAN'S RENEWABLE ENERGY ROADMAP}

According to the National Energy Board's 2017 Renewable Power Report, Saskatchewan's 2016 generation capacity included a mix of coal (33.6 percent), natural gas (40.8 percent), hydro ( 19.5 percent), wind ( 4.8 percent), and biomass ( 0.8 percent). ${ }^{389}$ There are no utility-scale solar projects in Saskatchewan. All renewable sources accounted for 25.1 percent of Saskatchewan's total generation capacity. ${ }^{390}$

Saskatchewan's electricity market is regulated and largely dominated by SaskPower, a Crown corporation, which has integrated generation, transmission, and distribution assets. There are also a number of generating facilities, both conventional and renewable energy, owned and operated by independent power producers. SaskPower also acts as the system operator and manages the system access services on the grid, similar to the AESO in Alberta. In this capacity, SaskPower is responsible for the implementation and administration of Saskatchewan's renewable energy programs and initiatives.

In 2015, Saskatchewan set a target of 50 percent of generation capacity from renewable sources by 2030 , which is expected to be accomplished through independent power producers. To achieve this ambitious goal, Saskatchewan will need to double the percentage

Alberta Electric System Operator, "Capacity Market Transition," online: $<$ https://www.aeso.ca/market/ capacity-market-transition/>.

See Alberta Electric System Operator, “Comprehensive Market Design (CMD)," online: $<$ https://www. aeso.ca/market/capacity-market-transition/comprehensive-market-design/>.

4th Sess, 29th Leg, Alberta, 2018 (as passed by the Legislature 19 April 2018), SA 2018, c 10 [Bill 13]. NEB Energy Market Analysis 2017, supra note 369 at 15-16.

Ibid. 
of renewables in its generation capacity mix from its current 25 percent to 50 percent. ${ }^{391}$ Similarly to Alberta, Saskatchewan has launched a competitive process for both solar and wind projects. Successful companies and projects will receive financial support through longterm Power Purchase Agreements (20 years for solar projects and 25 years for wind projects), that is energy-only contracts with no compensation for capacity or ancillary services. In contrast to Alberta, Saskatchewan has released a schedule for its short and longterm procurement of wind and solar renewable energy capacity between 2018 and 2031 .

Saskatchewan's solar plans include the procurement of:

- $60 \mathrm{MW}$ of utility-scale solar by 2021, specifically including two $10 \mathrm{MW}$ projects through procurement from independent power producers (SaskPower-led procurement);

- two $10 \mathrm{MW}$ projects in partnership with First Nations Power Authority; and

- $20 \mathrm{MW}$ through community-based and driven projects. ${ }^{392}$

The RFP process for these solar projects is complete and contracts are expected to be awarded in early 2018. The proposed long-term outlook for solar procurement in Saskatchewan includes an additional $60 \mathrm{MW}$ in 2025 and a further $60 \mathrm{MW}$ in $2031 .{ }^{393}$

Saskatchewan's goal is to have 30 percent wind power capacity by $2030 .{ }^{394}$ The first round of RFPs for $200 \mathrm{MW}$ of wind capacity is complete and contracts are expected to be awarded by Q3 2018. Saskatchewan has also indicated that "[f]uture competitions may be focused on specific geographic areas to help balance the system." 395

In addition to wind and solar, SaskPower has also confirmed that it is "looking at the potential for hydro projects, hydro imports from other provinces, as well as the potential for biomass and geothermal power projects." ${ }^{396}$ All project proposals that fall outside of SaskPower's existing Distributed Generation program and any current or upcoming wind and solar competitive procurements could take advantage of Saskatchewan's Unsolicited Power Proposal (UPP) stream. For example, the UPP projects may include flare gas, biomass, biogas, wind, and alternative variation of technologies, including utility-scale projects. ${ }^{397}$ To further encourage the use of renewables, SaskPower also offers other renewable energy programs, including Net Metering, Small Power Producers, and Flare Gas Power Generation Program.

SaskPower, "The Path to 2030: SaskPower Updates Progress on Renewable Electricity," online: $<$ https:// www.saskpower.com/about-us/media-information/news-releases/2018/03/the-path-to-2030-saskpowerupdates-progress-on-renewable-electricity>.

SaskPower, "Renewables Roadmap," online: <https://web.archive.org/web/20171222132149/www.sask power.com/our-power-future/renewables-roadmap/>.

Supra note 391.

"Renewables Roadmap," supra note 392.

SaskPower, "Wind and Solar RFQ/RFP Process" (Presentation delivered at the Saskatchewan Renewables IPP and Supplier Information Session, Saskatoon, Saskatchewan, 17 November 2016) at slide 21 [SaskPower Presentation].

SaskPower, "Renewables Roadmap," supra note 392.

SaskPower Presentation, supra note 395 at slides 33-35. 


\section{BILl 13: AN ACT TO SECURE ALBERTA'S ELECTRICITY FUTURE}

On 19 April 2018, Bill 13, ${ }^{398}$ which introduces amendments to various existing legislation to address several utility and electricity-related issues, passed first reading in the Alberta Legislature.

Among other things, Bill 13 sets out the framework for establishing and enabling a capacity electricity market in Alberta. Alberta currently has an "energy only" market in which generators are paid only for the energy they generate and sell into the market. A capacity market introduces an additional market in which generators may compete for payments to keep generation capacity available to produce electricity when required. A capacity market is designed to ensure that enough generation is available when needed. Bill 13 includes a number of legislative amendments to the Electric Utilities Act ${ }^{399}$ necessary to enact a capacity market. These amendments include changes to the responsibilities of the AESO, the AUC, and the Market Surveillance Administrator, and the introduction of changes to the process of approving ISO rules by the AUC, including ISO rules necessary for the establishment and operation of the capacity market.

The first capacity auction is expected in 2019 , with the understanding that the capacity market will begin to operate in 2021. In the meantime, Alberta Energy will develop supporting regulations, the AESO will prepare technical designs and rules, and the AUC will develop rules for oversight and review. The AESO Comprehensive Market Design Proposal documents are discussed herein at Part VII.B.2.

\section{Alberta Utilities Commission DECISIONS OF INTEREST}

\section{AUC ORDERS REMOVAL OF HiSTORICAL TRADING REPORT}

On 17 May 2017, the AUC issued Decision 21115-D01-2017 $7^{400}$ and ordered the removal of the Historical Trading Report (HTR) from the AESO website.

The HTR is an hourly spreadsheet by AESO that anonymously discloses the price and quantity of each offer made to the power pool in that hour. The Market Surveillance Administrator (MSA) applied for its removal, submitting that subsection 6(1) of the Fair, Efficient and Open Competition Regulation, ${ }^{401}$ does not mandate the AESO publish the price and quantity details of each offer when it is made, and that near-immediate publication renders the information-sharing prohibition at section 3 of the Competition Regulation effectively meaningless. 
The majority of the AUC ordered the removal of the HTR but encouraged the development of a modified HTR. In a strong dissenting opinion, Commissioner Lyttle found that (a) the AESO is required to publish the Report under the Regulation; (b) its continued publication would be consistent with the fair, efficient, and open operation of the market; and (c) the relief requested by the MSA was inappropriate. ${ }^{402}$

TransAlta Corporation and TransCanada Energy Ltd. filed Review and Variance Applications of the decision. The AUC dismissed the application, noting that the existence of dissenting reasons does not in itself indicate an error in the majority's decision, and that a review applicant must satisfy the review panel that there is an error of law, fact, or jurisdiction in exactly the same way as where the decision does not include a dissent. ${ }^{403}$

\section{LINE LOSS PROCEEDING}

The Line Loss proceeding dates back to 2005, when a complaint was filed respecting the AESO's proposed new methodology for calculating transmission line loss factors assigned to generators (the Line Loss Rule). "Line losses" are the difference between the amount of energy put onto the transmission system and the amount ultimately delivered. After the Line Loss Rule was found to contravene the Transmission Regulation ${ }^{404}$ and the Electric Utilities Act, ${ }^{405}$ since 1 January 2006, the AUC determined the remedy for the contravention in three modules. The AUC has already heard Module A, in which it determined it had the jurisdiction to order a remedy to correct for unlawful line loss payments made pursuant to the Line Loss Rule; and Module B, in which the AUC directed a new methodology for determining loss factors on a go-forward basis starting 1 January 2017. On 18 December 2017, the AUC ruled on Module $C^{406}$

In the Module $C$ decision, the AUC first considered what methodology should be applied to calculate final loss factors between 1 January 2006 and 31 December 2016 (the Historical Period). The AUC approved a modified version of the Module B methodology for calculating loss factors for the Historical Period, noting that it is "best able to reasonably represent (or emulate) what would actually happen on the [Alberta Interconnected Electric System]." 407

The second issue was to determine which parties should receive final invoices for the line losses for the Historical Period. All generators hold supply transmission service (STS) contracts with the AESO. The Commission considered to whom final invoices should be

Re: Market Surveillance Administrator, supra note 400 at paras 265-349.

Applications to Review and Vary Decision 21115-D01-2017 (11 December 2017), 22797-D01-2017, online: AUC < www.auc.ab.ca/regulatory_documents/ProceedingDocuments/2018/22797-D01-2017. pdfs.

Alta Reg 86/2007.

Supra note 365 .

Complaints Regarding the ISO Transmission Loss Factor Rule and Loss Factor Methodology, Phase 2 Module C (18 December 2017), 790-D06-2017, online: AUC < www.auc.ab.ca/regulatory documents/ ProceedingDocuments/2017/790-D06-2017.pdf $>$ [Module C]. Note that in Complaints Regarding the ISO Transmission Loss Factor Rule and Loss Factor Methodology, Phase 2 Module C - Preliminary Issues (28 September 2016), 790-D04-2016, online: AUC < www.auc.ab.ca/regulatory_documents/ ProceedingDocuments/2016/790-D04-2016.pdf>, the Commission ruled on several preliminary issues in Module $\mathrm{C}$ that the Commission considered could be addressed without the need for revised loss factors based on the compliant loss factor rule being established in Module B.

Module C, ibid at para 77. 
issued, where the holder of an STS contract had changed after 1 January 2006. The AUC directed the AESO to re-issue final invoices for loss charges or credits to the same parties that had received the original (interim) invoices during the Historical Period. ${ }^{408}$

The Line Loss proceeding remains contentious amongst the parties. The Commission ruled in January 2018 that it would not entertain any review applications of the Line Loss proceeding decisions as it was not in the public interest to do so and so that permission to appeal processes before the Court of Appeal could proceed expeditiously. ${ }^{409}$ Applications for permission to appeal aspects of Modules $\mathrm{A}$ and $\mathrm{C}$ of the Line Loss proceeding decisions are set to be heard by the Court of Appeal on 31 May and 1 June 2018.

\section{AUC DISTRIBUTED GENERATION REPORT}

On 31 March 2017, the Alberta government issued an Order in Council directing the Alberta Utilities Commission (AUC) to inquire into and report to the Alberta Minister of Energy on matters relating to alternative and renewable Electric Distribution SystemConnected Generation (DCG). The AUC set out a schedule for stakeholder consultation in April 2017, and forty-nine parties indicated their interest in participating in the proceedings and 10 parties registered as observers. ${ }^{410}$

In Alberta, DCG is smaller-scale electricity generation that connects directly to a local electric distribution system at 25 kilovolts $(\mathrm{kV})$ or less for the purpose of exporting electrical energy to that distribution system. ${ }^{411}$ Unlike microgeneration, which is regulated under the Alberta Micro-Generation Regulation, ${ }^{412}$ DCG is not limited by a five-megawatt generation capacity. Generators who are registered as a pool participant with the AESO receive cash from the AESO at pool prices. ${ }^{413}$ As a result, DCG allows more consumers to generate electricity for themselves and those around them, creating a two-way power flow within the system.

A final draft of the report was due to the Minister on 27 December 2017, but at the time of writing has not been released to the public. The purpose of the report is to identify barriers to DCG. Based on the questions circulated, the report is expected to explore:

- $\quad$ issues around billing and electrical energy settlement systems;

- $\quad$ costs and benefits of infrastructure investments that would facilitate broader deployment of alternative and renewable DCG;

$408 \quad$ Ibid at para 127

409 Alberta Utilities Commission, Letter to Parties (26 January 2018), re: Applications to review and vary decisions 790-D03-2015, 790-D04-2016, 790-D05-2016, and 790-D03-2017 at paras 4-6, Exhibit 790X3487.

410 Letter from Maria Baitoiu to Parties currently registered on Proceeding 22534 (1 May 2017), online: $<$ www.auc.ab.ca/regulatory_documents/Consultations/2017-05-01-DistributedGen-processLetter.pdf > [May 2017 AUC Letter].

411 Alberta Electric System Operator, "Guide for Distribution Connected Generation," online: $<$ https:// www.aeso.ca/downloads/Guide_for_Distribution_Generation_Fact_Sheet_020311.pdf>.

$412 \quad$ Alta Reg 27/2008.

413 Alberta Utilities Commission, "Micro-Generation Notice Submission Guideline: Version 2.0" (20 September 2017) at 2, online: <www.auc.ab.ca/regulatory_documents/Reference/Microgeneration NoticeSubmissionGuidelines.pdf>. 
- $\quad$ opportunities not captured under the Micro-Generation Regulation; and

- $\quad$ any rights, responsibilities, and obligations in the Alberta electricity industry that might limit provincial government policy initiatives in DCG. ${ }^{414}$

\section{E. British COLUmbia Hydro's Standing OfFer Programs: Five OfFers Made to First Nations}

In August 2017, British Columbia Hydro (BC Hydro) announced a suspension of applications for the Standing Offer Program (SOP) until a review of the SOP and Micro SOP, conducted with input from the provincial government and from Clean Energy BC (an organization that represents independent power producers), is complete.

On 14 March 2018, BC Hydro announced that it is pursuing Electricity Purchase Agreements (EPA) for clean energy projects with five First Nations that are either part of Impact Benefit Agreements with BC Hydro or mature projects that have significant First Nations involvement. The EPAs were offered under BC Hydro's SOP and Micro SOP, and are still subject to negotiation. ${ }^{415}$

The five projects include:

1. Tsilhqot'in Solar, a $1 \mathrm{MW}$ solar power project led by Tsilhqot'in National Government near Hanceville;

2. Siwash Creek, a $500 \mathrm{KW}$ hydroelectric project in partnership with Kanaka Bar Indian Band near Boston Bar;

3. Sarita River, a $5 \mathrm{MW}$ hydroelectric project led by Huu-ay-aht First Nation near Bamfield;

4. Sakunka Wind, a $15 \mathrm{MW}$ wind power project led by Saulteau First Nations near Chetwynd; and

5. Zonnebeke Wind, a $15 \mathrm{MW}$ wind power project with West Moberly First Nations near Chetwynd. ${ }^{416}$

At the time of writing, these offers are still subject to negotiation. BC Hydro states that it is not planning on issuing any additional EPAs until the review is complete.

$414 \quad$ May 2017 AUC Letter, supra note 410.

415 BC Hydro, "Standing Offer Program"(31 August 2018), online: < https://www.bchydro.com/work-withus/selling-clean-energy/standing-offer-program/program-documents.html $>$. The SOP is a noncompetitive, streamlined process for small, clean energy projects. Those offered an EPA are paid a predetermined price. The Micro SOP is a similarly streamlined process with set pricing, but requires a project have significant First Nations beneficial ownership and participation.

416 BC Hydro, News Release, "BC Hydro to Proceed with Five First Nations' Clean Energy Projects" (14 March 2018), online: $<$ https://www.bchydro.com/news/press_centre/news_releases/2018/bc-hydro-toproceed-with-five-first-nations--clean-energy-projec.html $>$. 


\section{F. Alberta Utility Commission - Alberta EnVironment AND PARKS AgreEMENT ON RESPONSIBILITIES Regarding Wind and Solar Power Plants}

On 1 February 2018, the AUC and AEP released an agreement confirming their roles and responsibilities over wind and solar plants in Alberta ${ }^{417}$ The clarification follows the AUC's investigation into breaches of wildlife conditions at the Oldman 2 wind farm, which is discussed in more detail at Part VIII.F.

Prior to filing an application with the AUC, an applicant must first apply to the AEP to obtain a referral report from AEP. The referral report forms part of the materials that the AUC considers in reviewing the project application. In granting an approval, the AUC may include any conditions it considers appropriate, including wildlife conditions.

The AEP retains regulatory responsibility and authority over impacts to wildlife or habitat that may require a separate approval from AEP. The AUC will continue to be responsible for all non-environmental and environmental matters of power plant operations. While the AUC is responsible for the monitoring of power plants and is usually the point of contact for external complaints regarding the plants, the AUC will provide the AEP with wildlife-related reports or complaints and may ask the AEP to respond.

\section{G. RECLAMATION CERTIFICATE REQUIREMENT InTRoduced For Renewable PoWer Projects}

The Alberta government introduced legislative amendments in the 2017 Renewable Electricity $A c t^{418}$ to add wind and solar electricity generation to the Schedule of Activities set out in the Environmental Protection and Enhancement Act, ${ }^{419}$ making each an "activity" under the EPEA. The EPEA requires operators to conserve and reclaim specified land, where "specified lands" includes lands in respect of which an activity is or has been carried on. ${ }^{420}$ As a result of the amendments to the EPEA, wind and solar electricity generators will now be required to reclaim the land on which their activities take place in accordance with the standards set out in the Conservation and Reclamation Regulation, ${ }^{421}$ and associated policy documents. $^{422}$

\section{H. British Columbia Site C Decision}

\section{The DeCision to PROCEED}

The approval and construction of the Site C Hydroelectric Dam — an 1,100 MW hydroelectric dam on the Peace River in Northern British Columbia - has been a source of

Alberta Environment and Parks \& Alberta Utilities Commission, "Roles and Responsibilities of Alberta Environment and Parks (AEP) and the Alberta Utilities Commission (AUC)" (1 February 2018), online: $<$ www.auc.ab.ca/regulatory_documents/Reference/AEP-AUC-rolesReponsibilities-windSolar.pdf $>$. 
controversy and has faced opposition from affected First Nations, local land owners, and environmental groups. Following its election in 2017, British Columbia's New Democratic Party government (the Province) referred Site $\mathrm{C}$ to the British Columbia Utilities Commission (BCUC) to conduct an inquiry into the costs and implications associated with completing, suspending, or cancelling the construction of the project. On 11 December 2017, following the BCUC's report (the Report), ${ }^{423}$ the Province announced its decision to proceed with the construction of the Site C Dam.

The Province's decision was based predominantly on the costs associated with cancelling the project, which has been under construction since 2015. The costs of cancellation would have amounted to approximately $\$ 4$ billion with "nothing in return," and would have led to rate hikes or reduced funds to other infrastructure projects. ${ }^{424}$ The $\$ 4$ billion loss would have included the $\$ 2.1$ billion already spent on the project, and $\$ 1.8$ billion in termination costs arising from contract cancellations and other unavoidable remediation costs.

Site $\mathrm{C}$ is not on track to meet either its 2024 completion date or its $\$ 8.2$ billion budget. In its news release, the Province announced a "turnaround plan" to help rein in the costs of Site $\mathrm{C}$ and to add benefits to the project. ${ }^{425}$ The "turnaround plan" will include:

- a new "Project Assurance Board" made up of BC Hydro, independent experts, and government representatives, to provide oversight over future contract procurement and management, project deliverables, environmental matters, and quality assurance within the project timeline and budget, which has been revised to $\$ 10.7$ billion;

- a new community benefits program mandated to ensure that the project provides benefits to local communities and increase the number of apprentices and First Nations workers on the project; and

- a new British Columbia Food Security Fund based on Site C revenues and dedicated to supporting farming and agricultural innovation and productivity in the province.

The "turnaround plan" will also activate a \$20 million agricultural compensation fund to offset lost sales and stimulate agriculture in the Peace Region, and to implement solutions to longer-term environmental, social, and economic issues.

\section{IMPACT ON INDEPENDENT POWER PRODUCERS}

As a result of Site C, independent power producers (IPPs) will likely see fewer opportunities in alternative energy in British Columbia. While some existing alternative

British Columbia Utilities Commission, British Columbia Utilities Commission Inquiry Respecting Site C: Final Report to the Government of British Columbia (Vancouver: BCUC, 1 November 2017) [BCUC Report].

Office of the Premier, News Release, "Government Will Complete Site C Construction, Will Not Burden Taxpayers or BC Hydro Customers with Previous Government's Debt" (11 December 2017), online: $<$ https://news.gov.bc.ca/releases/2017PREM0135-002039> [Site C Release]. Ibid. 
energy projects may continue, the completion of Site $\mathrm{C}$ may lead to a saturated British Columbia market, pushing IPPs to pursue projects in other jurisdictions. The Report noted that heritage resources are currently the largest part of BC Hydro's energy supply at approximately 75 percent. IPPs and anticipated renewals are at 24 percent and the Standing Offer Program, which encourages the development of small and clean or renewable projects, is at 1 percent. BC Hydro anticipates that, excluding Site $\mathrm{C}$ and Revelstoke 6 (a proposed generating station to be built by 2026), the level of heritage resource will likely not change, but IPP will drop to just under 21 percent, and reliance on the Standing Offer Program will increase. $^{426}$

Notably, there may still be opportunities for some electricity projects: in a backgrounder to its announcement of 11 December 2017, the Province stated that it will consider developing a new procurement strategy for smaller-scale renewable electricity projects where First Nations are proponents or partners, which would expand or complement BC Hydro's existing Standing Offer Program. ${ }^{427}$

\section{Notable DeCisions BEFORE THE ALBERTA ENERGy REgUlator AND THE Alberta UTILITIES COMMISSION}

\section{A. Prosper Petroleum Ltd. Rigel Oilsands Project - AER APPLICATION No. 1778538}

Early this year, the AER Panel heard evidence from Prosper Petroleum Ltd. (Prosper), the Fort McKay First Nation (FMFN), and the Fort McKay Métis (FM Métis, collectively, the Parties), in respect to a proposed project in the region of Wood Buffalo. This evidence was heard during an eight-day hearing in Fort McMurray from 9-18 January 2018. Final arguments were held in Calgary on 14 March 2018.

\section{BACKGROUND}

Prosper applied under the Oil Sands Conservation Act, ${ }^{428}$ the EPEA, ${ }^{429}$ and the Water $A c t^{430}$ for licenses and permits required for the operation of its proposed in situ Rigel Oil Sands Project.

The Rigel Oil Sands Project is a bitumen recovery scheme that would use steam-assisted gravity drainage (SAGD) to produce up to 1,600 cubic meters (10,000 barrels) of bitumen per day. It requires a Central Processing Facility (CPF), observation wells, water source wells, steam generation facilities, production facilities, water treatment and recycling 
facilities, pipelines, support infrastructure, an access road, borrow pits, and a construction pad. Prosper estimates the overall footprint of the project would be 106 hectares. $^{431}$

The community of Fort McKay is located approximately 64 kilometers away from the Rigel Oil Sands Project site. The FMFN and the FM Métis appeared at the hearing to contest the project. The FMFN suggested that a 10-kilometer buffer-zone should be applied around the culturally significant Moose Lake area wherein no industrial development should be permitted, and that the project is constrained by the FMFN's priority drinking water rights at its reserves at the hamlet of Fort McKay. ${ }^{432}$

The FM Métis contested the project on the basis that it is not in the public interest due to its impacts on the FM Métis' constitutionally protected harvesting rights; that the applications were deficient and not in compliance with applicable legislation, policies and guidelines; and that the Rigel Oil Sands Project may have potential unacceptable impacts on the drinking water of members residing in Fort McKay. ${ }^{433}$

\section{ACO HEARING RePORT PROCESS}

The hearing was attended by representatives of the ACO. The ACO manages the consultation process and assesses adequacy of the same. ${ }^{434}$ Following the initial eight days of the hearing, the proceedings were adjourned pending the issuance of the ACO hearing report. This process was intended to allow the ACO to consider all of the evidence that was presented during the hearing process and update the preliminary or interim adequacy decisions, as needed. The hearing report may also contain advice on whether actions may be required to address potential adverse impacts on treaty rights and traditional uses raised in the hearing. Upon reviewing the evidence heard during the first part of the hearing, the ACO prepared its hearing report and provided a copy to the AER Panel and the Parties on 22 February $2018 .^{435}$ This report was entered onto the record and marked as an exhibit to the proceeding.

\section{DECISION}

At the close of final arguments on 14 March 2018, the AER Panel indicated that a decision would be released within 90 days. At the time of writing no decision has yet been released.

Alberta Energy Regulator, "Decision 2018 ABAER 005: Prosper Petroleum Ltd., Rigel Project" (12 June 2018) at paras 5, 7, 62, online: <https://www.aer.ca/documents/decisions/2018/2018-ABAER005.pdf $>$. 


\section{B. Bashaw OIL Corporation: ApPlications FOR \\ Proximity Critical Sour Wells: \\ Nisku Formation, DRAYTON VALLEy AREa}

On 28 March 2018, the AER released its decision on Bashaw Oil Corporation's (Bashaw) applications for proximity critical sour wells (the Applications). ${ }^{436}$ The AER denied the Applications without prejudice to any future application by Bashaw.

\section{BACKGROUND}

Between October 2015 and February 2016, Bashaw filed three applications under the Oil and Gas Conservation Rules ${ }^{437}$ for the drilling and operation of three proximity critical sour wells. ${ }^{438}$ In 2017, Bashaw applied for related Water Act applications to infill and affect marsh and wetland areas during the construction of the proposed well pad. The AER panel heard the applications from 13 to 21 December $2017 .{ }^{439}$ Some of the primary issues identified by the panel in the proceedings included the degree and adequacy of community consultation; effects on safety, nuisance, health, and the environment; and Bashaw's emergency preparedness and response. ${ }^{440}$

\section{CONSUltation}

The AER Panel concluded that the community consultation done by Bashaw was inadequate. Under Directive 056, applicants are required to implement effective consultation plans prior to filing applications with the AER. Bashaw adduced that in light of the opposition from community members it chose to complete most of its participant outreach after submitting the Applications. ${ }^{441}$ The Panel was not persuaded that Bashaw was respectful, responsive, and responsible in its consultations and reiterated that the onus was on Bashaw to plan and implement effective consultation, despite how difficult it may have been. ${ }^{442}$ The Panel also found that as a result of inadequate consultation, Bashaw had insufficient site-specific information, leading to significant gaps in the emergency response plan.

\section{EMERGENCY PREPAREDNESS AND RESPONSE}

Regarding Bashaw's ability to respond in light of an emergency, the Panel was not confident that Bashaw was sufficiently prepared to ensure public safety. ${ }^{443}$ The Panel concluded that plans for the evacuation of horses and other animals, health and mobility issues, alternate egress, and spotty cell phone coverage were not sufficiently considered by

\footnotetext{
436 Bashaw Oil Corporation Applications for Proximity Critical Sour Wells Nisku Formation, Drayton Valley Area, 2018 ABAER 002 [Bashaw].

Alta Reg 151/1971.

Bashaw, supra note 436.

Ibid at para 15 .

Ibid at para 16

Ibid at para 31 .

Ibid at para 40.

Ibid at para 87 .
} 
Bashaw due to the poor consultations it conducted. ${ }^{444}$ The Panel stated that Directive $071^{445}$ outlines the minimum requirement for alternate egress; however, sometimes these requirements may need to be exceeded in order to ensure public safety, which was not done here. ${ }^{446}$ Generally, the Panel found that even where Directive 071 does not mandate specific actions, given the potential threat to human safety when dealing with sour gas wells, all levels of emergencies need to be considered. ${ }^{447}$

\section{OTHER CONSIDERATIONS}

The Panel concluded that in light of the safety-related impacts associated with the project, any potential social or economic benefit it might bring is outweighed. ${ }^{448}$ The Panel also denied the corresponding Water Act applications since following the denial of the well applications, the activities for which the approvals were needed were no longer relevant. ${ }^{449}$

The Panel also noted that in the prehearing meeting decision, there was discussion regarding Bashaw's financial capacity to carry out its responsibilities in a safe manner. However, since no evidence was adduced to this effect, the Panel did not consider this in the hearing. ${ }^{450}$

\section{CONCLUSION}

In this case, the Panel balanced a number of issues relevant to the energy industry including environmental and health impacts, public safety, economic viability, impact on landowners, and community engagement. The consideration of these factors resulted in a denial of the Applications without prejudice to Bashaw's reapplication in the future.

\section{White Spruce Pipeline Project - DECISION 2018 ABAER 001}

On 22 February 2018, the AER approved TransCanada's application to construct the White Spruce Pipeline Project (White Spruce), which would deliver synthetic crude oil 71 kilometres from the Canadian Natural Resources Limited's Horizon processing plant to the Grand Rapids Pipeline GP Ltd. MacKay Terminal for delivery to markets. ${ }^{451}$ The Fort McKay First Nation (Fort McKay") was the only participant in the hearing before the AER. $^{452}$

Alberta Energy Regulator, "Directive 071: Emergency Preparedness and Response Requirements for the Petroleum Industry" (2 February 2017), online: $<$ https://www.aer.ca/documents/directives/Directive 071.pdf>.

446 Bashaw, supra note 436 at para 84.

$447 \quad$ Ibid at para 83.

$448 \quad$ Ibid at para 102.

$449 \quad$ Ibid at para 103.

$450 \quad$ Ibid at para 17.

451 TransCanada Pipelines Limited Applications for the White Spruce Pipeline Project Fort McKay Area, 2018 ABAER 001 at paras 1-2 [White Spruce Decision]. 
In addition to the typical factors, the AER decision dealt with two notable issues in its decision.

First, the AER declined to make a direct finding of cumulative effects on treaty and aboriginal rights. Fort McKay asserted that White Spruce, when combined with other industrial development in their traditional territory, would result in adverse cumulative effects on their treaty and aboriginal rights. ${ }^{453}$ The effects claimed included a reduction in the area in which the members of Fort McKay may exercise their treaty and aboriginal rights in a culturally relevant way; negative effects on food and resource gathering; reduced connection to community, history, and knowledge about traditional use; and concerns about health and safety risks. ${ }^{454}$ Fort McKay pointed to the Shell Canada Energy, Jackpine Mine Expansion Project decision, ${ }^{455}$ in which a joint review panel found that there were cumulative adverse effects on some elements of Fort McKay's cultural heritage, as support for a finding of adverse cumulative effects. ${ }^{456}$

The AER first noted that, pursuant to section 20 of the Responsible Energy Development Act ${ }^{457}$ it is required to comply with the Lower Athabasca Regional Plan (LARP) when considering cumulative effects; however, "[w]hile LARP is Alberta's vehicle to address cumulative effects in the Lower Athabasca region, it does not currently set any specific limits or thresholds related to the cumulative effects of development on aboriginal rights. ${ }^{, 458}$ In the absence of any other legislative or regulatory limits, and given the evidence presented, the AER determined that the concerns raised were "general in nature" and not supported by adequately specific evidence to allow the panel to make a finding of impact or impose conditions. ${ }^{459}$ The AER also refused to draw a comparison with the cumulative effects assessment conducted in the Jackpine Decision, noting that Fort McKay had failed to provide the specific assessment of the Fort McKay area relied on in the Jackpine Decision, and as a result had insufficient evidence on how the findings in the Jackpine Decision would specifically apply to the particular effects claimed by Fort McKay arising from this Project. ${ }^{460}$

Second, the AER required TransCanada to restore two times the caribou habitat as would be newly disturbed by White Spruce. The AER found that the measures proposed by TransCanada to mitigate the effects of pipeline construction on the habitat of the West Side Athabasca River caribou herd would not provide as significant a contribution to the restoration of critical habitat as suggested by TransCanada. ${ }^{461}$ As a result, and as a condition of approval, the AER required TransCanada to prepare and submit a caribou habitat restoration plan that will have the effect of restoring two times the area of new cut by White Spruce within the West Side Athabasca Range. ${ }^{462}$ "The goal or outcome of the plan is to

\footnotetext{
$453 \quad$ Ibid at para 64.

454 Ibid.

455 Shell Canada Energy Application to Amend Approval 9756 Jackpine Mine Expansion Project Fort McMurray Area, 2013 ABAER 011 [Jackpine Decision].

White Spruce Decision, supra note 451 at para 66.

SA 2012, c R-17.3.

White Spruce Decision, supra note 451 at para 69.

Ibid at para 71 .

Ibid at para 70 .

Ibid at para 130.

Ibid at para 133 .
} 
ensure that there is, at a minimum, no net loss of caribou habitat from the project in the West Side Athabasca Range." 463

\section{JASPER INTERCONNECTION PROJECT - AUC Proceeding 22125}

AUC approval was sought by the AESO for a needs identification document application, requesting approval of a transmission line to link the Municipality of Jasper (Jasper) to the Alberta Interconnected Electric System (AIES). ${ }^{464}$ Concurrently, applications to construct and operate the required facilities were made by ATCO Electric Ltd. (ATCO) and AltaLink Management Ltd. (AltaLink) under the Hydro and Electric Energy Act. ${ }^{465}$ The applications included requested approval for the construction and operation of a new substation, a singlecircuit 69-kilovolt transmission line, and to upgrade the existing Watson Creek 104S substation (collectively, the Jasper Interconnection Project) in and around Jasper National Park. ${ }^{466}$ The proposed location of the new substation is approximately 8 kilometers north of Jasper.

The Jasper Interconnection Project is unique given the fact that Jasper is not currently linked to the AIES and, as such, is an "isolated community" as that term is defined and used in the Isolated Generating Units and Customer Choice Regulation. ${ }^{467}$ Given the unique nature of the project, the Commission was essentially required to make a determination of whether it is in the public interest to supply Jasper with electricity through a transmission solution or to continue using an isolated generation system.

On 4 May 2018, the AUC released its decision approving the Jasper Interconnection Project, and finding it in the public interest. The AUC determined that any environmental effects could be effectively mitigated, and that the project constituted the "lowest cost option." ${ }^{468}$

Due to its location within Jasper National Park, the project must also be assessed by Parks Canada under the CEAA, 2012, ${ }^{469}$ in accordance with the Parks Canada Directive on Impact Assessment, 2015, ${ }^{470}$ which requires power-line projects to undertake a Detailed Impact Assessment. In conjunction with this process, the Jasper Interconnection Project must obtain

Ibid.

Alberta Utilities Commission, "Application of the Alberta Electric System Operator for Approval of the Sheridan 2085S Substation Needs Identification Document," Application 22125-A001 (28 October 2016).

RSA 2000, c H-16.

Alberta Utilities Commission, "Application to the Alberta Utilities Commission - ATCO Jasper Interconnection near the Town of Hinton, Alberta," Application 22125-A002 (30 November 2016); Alberta Utilities Commission, "Application to the Alberta Utilities Commission - ATCO Jasper Interconnection near the Town of Hinton, Alberta," Application 22125-A003 (30 November 2016); Alberta Utilities Commission, "Jasper Interconnection Project - Application to the Alberta Utilities Commission," Application 22125-A004 (December 2016).

Alta Reg 165/2003 [IGUCCR].

Alberta Electric System Operator Needs Identification Document Application (4 May 2018), 22125 D01-2018 at para 388, online: AUC <www.auc.ab.ca/regulatory_documents/ProceedingDocuments/ 2018/22125-D01-2018.pdf>.

Supra note 183.

Parks Canada, Guide to Parks Canada Environmental Impact Analysis Process, June 2015 (Ottawa: Parks Canada, 19 June 2015). 
a development permit from Parks Canada under the Canadian National Parks Act. ${ }^{471}$ Once constructed, the project will link Jasper to the AIES and Jasper will no longer be considered an "isolated community" under the IGUCCR.

\section{E. Performance-Based Regulation REbASING AND First COMPLIANCE FILING - DECISION 22394-D01-2018}

On 12 December 2016, the AUC issued Decision 20414-D01-2016, ${ }^{472}$ in which it established the parameters for the second generation of Performance Based Regulation (PBR) for Alberta's electric and gas distribution utilities (ATCO Electric Ltd., ENMAX Power Corporation, EPCOR Distribution \& Transmission Inc., FortisAlberta Inc., AltaGas Utilities Inc., and ATCO Gas and Pipelines Ltd.). The first generation of PBR plans expired on 31 December 2017. In Decision 20414-D01-2016, the Commission made several changes to the first generation PBR plans, including with respect to capital funding, and determined that the going-in rates for 2018-2022 would be based on the notional 2017 revenue requirement calculated in the manner outlined below. The distribution utilities were directed to file a compliance filing by way of a rebasing application in accordance with the directions in Decision 20414-D01-2016.

On 5 February 2018, the AUC issued its First Compliance Proceeding decision, ${ }^{473}$ in which it partially accepted the first compliance filing of distribution utilities and directed them to provide additional information in the second compliance filing.

One major issue in the First Compliance Proceeding was the establishment of base operations and maintenance (O\&M) costs for the 2018-2022 term. In Decision 20414-D012016, the AUC had directed that the utilities' O\&M costs, which form a large component of the revenue requirement, would be set based on the lowest year of 2013-2016 actual costs adjusted by index factors for inflation, productivity, and customer growth, and with adjustments, as necessary, to reflect material "anomalies." Although the Commission generally accepted the lowest-cost year for O\&M costs identified by each of the distribution utilities for the purposes of calculating the notional 2017 revenue requirement, it denied the utilities' applied-for anomalies as not meeting the Commission's anomaly criteria.

In the First Compliance Proceeding, the Commission also modified the incremental capital funding mechanism approved in Decision 20414-D01-2016. In Decision 2014-D012016, in place of the capital tracker mechanism employed in the first generation of PBR, the AUC determined that incremental capital funding should be divided into two categories. Any capital classified as Type 1 (or " $\mathrm{K}$ " factor) would be limited to third-party driven programs that have never occurred before and do not qualify under a " $Z$ " factor (which is an exogenous and material event for which the utility has no other reasonable cost recovery or refund

$471 \quad$ SC 2000, c 32.

472 2018-2022 Performance-Based Regulation Plans for Alberta Electric and Gas Distribution Utilities (16 December 2016), 20414-D01-2016, online: AUC <www.auc.ab.ca/regulatory_documents/Proceeding Documents/2016/20414-D01-2016\%20\%28Errata\%29.pdf>.

473 Rebasing for the 2018-2022 PBR Plans for Alberta Electric and Gas Distribution Utilities - First Compliance Proceeding (5 February 2018), 22394-D01-2018, online: AUC <www.auc.ab.ca/regulatory_ documents/ProceedingDocuments/2018/22394-D01-2018.pdf $>$ [First Compliance Proceeding]. 
mechanism within the PBR plan). The AUC defined Type 1 capital using very narrow criteria that would capture the need for incremental funding under extraordinary circumstances. ${ }^{474}$ For any capital classified as Type 2, which is expected to include almost all capital of the distribution utilities, the AUC approved a new K-bar methodology based on a prescribed formula. The stated intent of the K-bar mechanism is to provide an amount of capital funding for each year of the second generation PBR plans based, in part, on capital additions made during the previous PBR term. ${ }^{475}$

In the First Compliance Proceeding, the AUC adjusted the previously approved mechanics for calculating the K-bar incremental capital funding. The AUC stated that based on the information provided by distribution utilities as part of the first compliance filing, the resulting annual funding level for the 2019-2022 period diverged from what the AUC intended when it established the principles behind the K-bar mechanism. ${ }^{476}$ Therefore, the AUC directed that for the 2019-2022 period, the K-bar incremental funding formula would be calculated each year using adjusted parameters for inflation, growth, and Weighted Average Cost of Capital to reflect the approved values for that year.

Other matters addressed in the First Compliance Proceeding included service quality and asset monitoring, 2017 cost of debt, and income tax implications, as well as other utilityspecific issues. The AUC directed each of the distribution utilities to file a second compliance filing by 1 March 2018 to address the AUC's directions, including the re-filing of comprehensive information regarding O\&M anomalies, re-calculated capital based on the adjusted K-bar formula, other utility-specific matters, and proposed 2018 PBR rates.

Review and variance applications, and applications for permission to appeal to the Court of Appeal, have been filed by several utilities that took issue with what are alleged to be new eligibility criteria established in the First Compliance Decision that had not been in the initial Decision 20414-D01-2016. ${ }^{477}$ The grounds for review include that the changes to the new Kbar mechanism allegedly underfund reasonable levels of capital investment over the next PBR term, and directions to maintain certain cost-of-service style placeholders appear inconsistent with the newly enunciated criteria. One utility has also sought leave to review and vary the initial Decision 20414-D01-2016 on the basis that if the "clarifications" of that decision rendered in the subsequent Compliance Decision were not new, they at least explain why it was not possible to review and vary the Decision 20414-D01-2016 until the "clarifications" were issued. ${ }^{478}$ At the time of writing, these matters are pending before the AUC.

\footnotetext{
$474 \quad$ Ibid at para 167.

$475 \quad$ Ibid at para 27.

$476 \quad$ Ibid at paras $185-88$.

477 ATCO Utilities, "Application by the ATCO Utilities for Review and Variance of Decision 22394-D012018 Determination Of Preliminary Question,” Application 23479-A002 (6 April 2018); ENMAX Power Corporation, "Application for Review and Variance of Decision 22394-D01-2018: Rebasing for the 2018-2022 PBR Plans for Alberta Electric and Gas Distribution Utilities, First Compliance Filing," Application 23479-A003 (6 April 2018); FortisAlberta Inc, "Application for Review and Variance of Decision 22394-D01-2018,” Application 23479-A001 (6 April 2018).

478 Request for Leave to File an Application for Review of Decision 20414-D01-2016 (Errata) (20 June 2018), 23479-D01-2018, online: AUC < www.auc.ab.ca/regulatory_documents/ProceedingDocuments/ 2018/23479-D01-2018.pdf>.
} 


\section{F. Alberta Utilities Commission ImPOSES \\ PENALTY ON Wind FARM FOR BREACH OF WiLdLIFE CONDITIONS}

In November 2016, the AUC commenced an investigation into whether Oldman 2 Wind Farm Ltd. (Oldman 2) had complied with the conditions of its approval after Alberta Environment and Parks raised concerns on the issue. ${ }^{479}$

The AUC investigation determined that Oldman 2 had failed to meet several conditions of its approval, including "(1) [failing to hire] an environmental monitor during construction, (2) failing to prevent disturbances to the [endangered \} ferruginous hawk and prairie falcon nest locations, and (3) failing to implement its post-construction mitigation plan." ${ }^{480}$

Oldman 2 cooperated in the investigation and, in December 2017, applied to the AUC for approval of certain amendments to address the issues of environmental compliance. Specifically, it proposed to add the following conditions to its new approval:

- implement the Construction Mitigation Plan;

- donate \$280,275 for habitat conservation in southern Alberta, including amounts for ferruginous hawk habitat protection and to benefit the species affected during construction; and

- maintain a project-wide Corporate Compliance Plan to adhere to regulatory commitments and conditions, and additional reporting and the proposed conditions. ${ }^{481}$

The AUC accepted the proposed conditions and decided against pursuing an enforcement remedy for the original non-compliances under section 63 of the Alberta Utilities Commission Act. ${ }^{482}$

\section{G. First MARKet Participant Choice Decision - DECISION 21394-D01-2017}

In June 2017, the AUC determined that the AESO's determination of need was correct and approved the construction and operation of the Jenner Wind Power Plant and its connection to the AIES. ${ }^{483}$

This is the first decision in which the AUC considered utilizing a market participant choice, as applications for new transmission facilities for the AIES are generally prepared

Oldman 2 Wind Power Project Environmental Compliance (26 January 2018), 23241-D01-2018 at para 4, online: AUC < www.auc.ab.ca/regulatory_documents/ProceedingDocuments/2018/23241-D012018.pdf>.

$480 \quad$ Ibid.

$481 \quad$ Ibid at para 5

482 SA 2007, c A-37.2.

483 Power Renewable Energy Corporation Facility Applications (16 June 2017), 21394-D01-2017, online: AUC $<$ www.auc.ab.ca/regulatory documents/ProceedingDocuments/2017/21394-D01-2017.pdf>. 
by the transmission facility operator (TFO). ${ }^{484}$ However, this outcome will allow the power plant operator, Power Renewable Energy Corporation, to build their own interconnection transmission line and substation before transferring ownership to the responsible TFO following construction. 